FABIANA DA SILVA PAULA

DIVERSIDADE E ESTRUTURA FUNCIONAL DE COMUNIDADES MICROBIANAS EM SOLOS DA AMAZÔNIA E RESPOSTA A MUDANÇAS NA FORMA DE USO DO SOLO

Tese apresentada ao Programa de Pós-Graduação em Microbiologia do Instituto de Ciências Biomédicas da Universidade de São Paulo, para obtenção do Título de Doutor em Ciências. 
FABIANA DA SILVA PAULA

\section{DIVERSIDADE E ESTRUTURA FUNCIONAL DE COMUNIDADES MICROBIANAS EM SOLOS DA AMAZÔNIA E RESPOSTA A MUDANÇAS NA FORMA DE USO DO SOLO}

Tese apresentada ao Programa de PósGraduação em Microbiologia do Instituto de Ciências Biomédicas da Universidade de São Paulo, para obtenção do Título de Doutor em Ciências.

Área de concentração: Microbiologia Orientadora: Profa. Dra. Vivian Helena Pellizari Versão corrigida. Versão original eletrônica encontra-se disponível tanto na Biblioteca do ICB quanto na Biblioteca de Teses e Dissertações da USP (BDTD). 
DADOS DE CATALOGAÇÃO NA PUBLICAÇÃO (CIP)

Serviço de Biblioteca e Informação Biomédica do

Instituto de Ciências Biomédicas da Universidade de São Paulo

๑ reprodução total

Paula, Fabiana da Silva.

Diversidade e estrutura funcional de comunidades microbianas em solos da Amazônia e resposta a mudanças na forma de uso do solo / Fabiana da Silva Paula. -- São Paulo, 2012.

Orientador: Profa. Dra. Vivian Helena Pellizari.

Tese (Doutorado) - Universidade de São Paulo. Instituto de Ciências Biomédicas. Departamento de Microbiologia. Área de concentração: Microbiologia. Linha de pesquisa: Microbiologia do solo.

Versão do título para o inglês: Functional diversity and structure of Amazon soil microbial communities and response to land use changes.

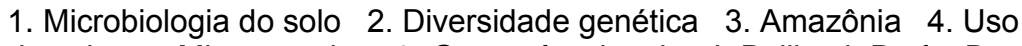
do solo 5. Microarranjo 6. Genes funcionais I. Pellizari, Profa. Dra. Vivian Helena II. Universidade de São Paulo. Instituto de Ciências Biomédicas. Programa de Pós-Graduação em Microbiologia III. Título. 
Título da Tese:

Diversidade e estrutura funcional de comunidades microbianas em solos da Amaz ônia e resposta a mudanças na forma de uso do solo.

Orientador(a):

Profa. Dra. Vivian Helena Pellizari.

A Comissão Julgadora dos trabalhos de Defesa da Tese de Doutorado, em sessão pública realizada a .. considerou

\section{( ) Aprovado(a) （ Reprovado(a)}

Examinador(a): Assinatura:

Nome:

Instituição:

Examinador(a): Assinatura:

Nome:

Instituição:

Examinador(a): Assinatura:

Nome:

Instituição:

Examinador(a): Assinatura:

Nome:

Instituição:

Presidente: Assinatura:

Nome:

Instituição: 


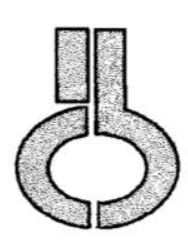

\section{CERTIFICADO DE ISENÇÃO}

Certificamos que o Protocolo CEP-ICB N ${ }^{\circ}$ 249/08, referente ao projeto intitulado: “Impacto do desmatamento e do manejo do solo na atividade funcional e taxonômica de microorganismos na Amazôniac sob a responsabilidade de Fabiana da Silva Paula, foi analisado na presente data pela CEEA - COMISSÃO DE ÉTICA EM EXPERIMENTAÇÃO ANIMAL e pela CEPSH - COMISSÃO DE ÉTICA EM PESQUISA COM SERES HUMANOS, tendo sido deliberado que o referido projeto não envolve manipulação animal ou humana que justifique uma aprovação quanto aos princípios éticos exigidos por ambas as Comissões.

São Paulo, 22 de abril de 2008.

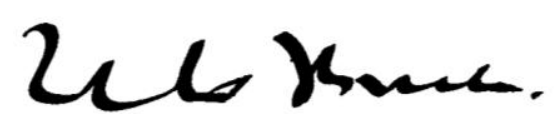

PROF. DR. WOTHAN TAVARES DE LIMA Coordenador da CEEA - ICB/USP

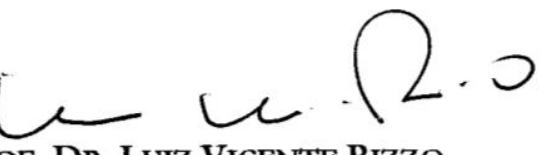

PROF. Dr. LUIZ VicENTE RIZZO Coordenador da CEPsh - ICB/USP 
Aos meus pais,

Algenira e lldefonso. 


\section{AGRADECIMENTOS}

À Profa. Dra. Vivian Helena Pellizari, pela orientação deste trabalho, contribuindo para a minha formação, pelos ensinamentos, pela confiança e pelas oportunidades oferecidas.

Ao Prof. Dr. Jorge Rodrigues, da University of Texas, por me receber tão gentilmente em seu laboratório e na cidade de Arlington, e pela contribuição com discussões e sugestões.

Ao Prof. Dr. Jizhong Zhou, do Institute for Environmental Genomics (University of Oklahoma), por me receber em seu laboratório e por disponibilizar as lâminas e a estrutura necessária para realização da técnica do Geochip. Agradeço também aos integrantes de seu laboratório, pela receptividade, e em especial Dr. Liyou Wu, Dra. Tong Yuan e Dr. Ye Deng, pelo apoio técnico e científico.

Ao Prof. Dr. Brendan Bohannan e à Rebecca Mueller, da University of Oregon, pelas contribuições para as análises estatísticas e por me receberem gentilmente em Eugene.

A todos integrantes do projeto ARMO ("Amazon Rainforest Microbial Observatory"), em especial Jorge Rodrigues, Brendan Bohannan, Klaus Nusslein, Rebecca Mueller, Kyunghwa Baek, Wagner Piccinini e Clovis Souza, com os quais tive o prazer de conviver durante das coletas das amostras em Rondônia. Além do trabalho pesado, tivemos muitas discussões produtivas e agradáveis momentos de descontração.

À Profa. Dra. Siu Mui Tsai e à Profa. Dra. Brigitte Josefine Feigl do CENA/USP por disponibilizarem os dados de análises físico-químicas das amostras de solo.

À Coordenação de Aperfeiçoamento de Pessoal de Nível Superior (CAPES), pelo suporte financeiro para a realização deste trabalho, por meio de bolsa de doutorado e de estágio sanduíche no exterior (PDEE), processo 0246-10-7. 
Aos colegas e amigos do Laboratório de Ecologia Microbiana do Instituto Oceanográfico (e anteriormente do Instituto de Ciências Biomédicas), Adriana Lopes, Adriana Torres, Ana Carolina Araújo, André Rodrigues, Camila Fernandes, Cristina Nakayama, Cristine Barreto, Débora Linhares, Daniella Vilela, Diego Castilho, Felipe Nóbrega, Juliana Cedro, Maitê Leite, Mariana Vasconcelos, Priscila Ushimaru, Rosa Gamba, Rubens Duarte e Simone Tessaro, pela convivência durante esses anos, no laboratório e fora dele. A gente acaba se tornando parte da vida um do outro. Obrigada também pelas discussões, sugestões e pelos auxílios em experimentos.

A todos os integrantes dos laboratórios dos Professores Jorge Rodrigues e Maeli Melotto, que me receberam carinhosamente, e ofereceram ajuda em meu trabalho e em minha adaptação em Arlington, TX.

Aos queridos amigos de São Paulo, e aos que estão distantes, mas que que mesmo após anos, a amizade continua como se eles estivessem na sala ao lado. Nos momentos difíceis é bom saber deixei alguns portos seguros pelo caminho.

Ao Enrico, que trouxe uma mistura de alegria e calmaria, e que tanto me incentivou em meus longos dias e noites de escrita.

Aos meus irmãos Frederico e Fernando pela amizade e pelo carinho de sempre, e por estarem sempre prontos para ajudar. E à minha sobrinha Clara, que era uma pequena menina na minha defesa de mestrado e agora é uma bela moça, pelo carinho.

Aos meus pais Ildefonso e Algenira. Não posso agradecer aqui tudo o eles que merecem, pois seria outra tese de doutorado. Vou me ater a agradecer pelo grande apoio que mais uma vez deram a esta aprendiz de cientista e por compreenderem minha ausência, que só se faz aumentar. Eles são minha banca examinadora preferida, pois sempre avaliam, mas mesmo que eu erre, continuam orgulhosos. 


\section{RESUMO}

PAULA, F. S. Diversidade e estrutura funcional de comunidades microbianas em solos da Amazônia e resposta a mudanças na forma de uso do solo. 2012. 107 f. Tese (Doutorado em Microbiologia) - Instituto de Ciências Biomédicas, Universidade de São Paulo, São Paulo, 2012.

Mudanças na cobertura vegetal e introdução de práticas agropecuárias têm sido apontadas como fatores importantes influenciando comunidades microbianas do solo. Impactos sofridos pela microbiota do solo são de grande interesse ambiental e agronômico, dada a sua importância realizando funções essenciais para o ecossistema, como a ciclagem de nutrientes. Na Amazônia já foi demonstrado que o desmatamento e o estabelecimento de pastagens alteram a estrutura taxonômica de comunidades bacterianas. Entretanto, não se sabe se essas alterações afetam o seu potencial funcional ou se a nova comunidade é funcionalmente redundante à original. Este trabalho buscou avaliar este parâmetro, sob a hipótese de que o uso do solo causa impacto na estrutura funcional da comunidade, assim como observado em estudos de taxonomia. Isso justificaria as alterações em taxas de processos de origem microbiana, observadas em trabalhos desenvolvidos anteriormente na região. Para avaliar a diversidade de genes funcionais foram coletadas amostras de solo de floresta primária, pastagens com diferentes tempos de uso (6, 38 e 99 anos) e floresta secundária em uma fazenda no Estado de Rondônia. Estas amostras foram submetidas à técnica de microarranjo de DNA, denominada Geochip, que contém mais de 80 mil sondas, específicas para 410 famílias de genes funcionais, relacionados a diversos processos, incluindo ciclos biogeoquímicos, degradação de compostos orgânicos, resistência a antibióticos, estresse e resistência a metais. Os resultados obtidos mostraram que a conversão de floresta em pastagem causou alteração da estrutura funcional da comunidade e redução significativa da diversidade de genes funcionais, e o estudo das amostras da floresta secundária sugeriu a ocorrência de restabelecimento da estrutura e diversidade original destes genes. Diferenças também foram observadas entre as pastagens, principalmente a de 99 anos, que apresentou resultados semelhantes às florestas, o que provavelmente se deve ao fato de possuir um diferente tipo de solo. Propriedades físico-químicas do solo se correlacionaram significativamente com a estrutura da comunidade, mostrando importância desses fatores para o perfil 
observado. Além das análises de comunidade, foi proposta a aplicação de um índice de associação, tradicionalmente utilizado para espécies, para avaliar se as famílias de genes funcionais estão significativamente mais presentes e abundantes em um ou mais ambientes. O teste revelou uma variedade de respostas entre as famílias de genes, mostrando que estas sofrem impactos do uso do solo de diferentes formas. As florestas primária e secundária tiveram um maior número de genes associados, comparando com as pastagens, sugerindo um maior potencial funcional nos sítios sob vegetação nativa. Finalmente, alguns genes se associaram à combinação das duas florestas o que pode indicar uma similaridade entre estes ambientes. Os dados mostraram que o desmatamento e a formação de pastagem na Amazônia causam impacto sobre o perfil funcional da microbiota do solo, o que pode refletir no seu potencial funcional. Por outro lado, a floresta secundária parece recuperar o perfil original, mostrando a importância deste ambiente como uma possível alternativa para o restabelecimento de funções relacionadas ao equilíbrio do ecossistema na Amazônia.

Palavras-chave: Amazônia. Uso do solo. Diversidade de genes funcionais. Geochip. 


\begin{abstract}
PAULA, F. S. Functional diversity and structure of Amazon soil microbial communities and response to land use changes. 2012. $107 \mathrm{f}$. Thesis (PhD in Microbiology) - Instituto de Ciências Biomédicas, Universidade de São Paulo, São Paulo, 2012.
\end{abstract}

Land use changes have been pointed out as important factors affecting soil microbial communities. Impacts on soil microorganisms are of environmental and agronomic interest, since they play essential role in ecosystem maintenance, performing important processes, such as nutrient cycling. Studies carried out in Amazon forest have reported that pasture establishment alters the taxonomic structure of soil bacterial communities. However, it is still not clear if the functional structure also changes or the new microbial community is functionally redundant to the original one. This study evaluated the impacts of land use on functional community structure and diversity in Amazon soils. Considering that changes in microorganism-related processes under this system were previously reported, we hypothesized that the functional structure would be altered, similarly to the taxonomic one. For this purpose, soils from primary forest, pastures with different time of use (6, 38 and 99 years) and secondary forest were sampled in a cattle ranching area, in Rondônia State. In order to access the functional gene diversity, a microarray technique, named Geochip, was employed. Geochip contains more than 80,000 probes for 410 functional gene families, related to important process, including biogeochemical cycles, organic compound degradation, antibiotic resistance, stress and metal resistance. The results showed that forest to pasture conversion led to functional structure changes and functional gene diversity loss, whereas it was found that secondary forest had a profile similar to the primary forest. Differences among pastures were also observed, mainly regarding to the 99 years old, which exhibited diversity and structure similar to the forests. This distinct response was attributed to the different soil type of this pasture. Significant correlations between soil physicalchemical properties and the community structure were found, suggesting that soil characteristics are affecting the microbiota functional profile. In addition to the traditional community analysis, this study proposed the use of an association index, which is traditionally applied for species, to evaluate the distribution of gene families. 
Based on presence and abundance, the index analyzed if the gene is significantly associated to single sites or site combinations. A range of responses was found for the gene families, indicating that the land use might be impacting the functional groups in different ways. The primary and secondary forests had a greater number of associated gene families, which suggests a higher functional genetic potential in soils under native vegetation. Additionally, several genes associated to the combination of the two forests, indicating similarity between these sites. The data showed that agriculture practices in Amazon promote changes on functional profile of soil microbial communities, which might be impacting their functional potential. On the other hand, the original profile seems to be recovered in the secondary forest, pointing out the possible importance of this environment reestablishing functions for ecosystem maintenance in Amazon rainforest.

Keywords: Amazon. Land use. Functional gene diversity. Geochip 


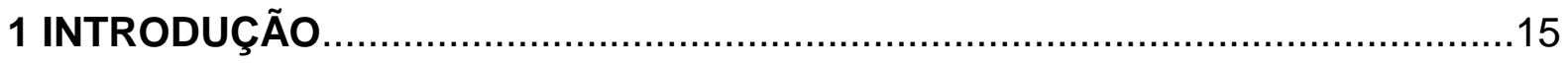

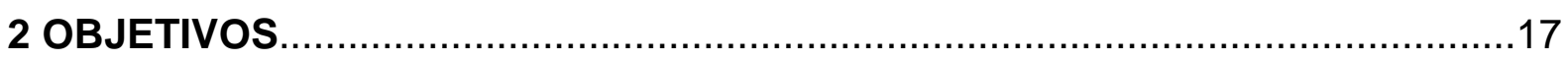

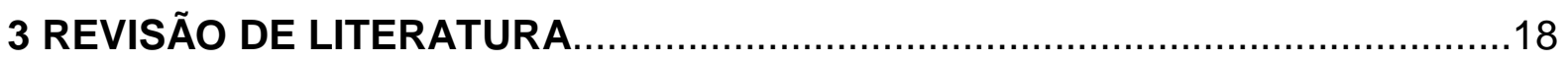

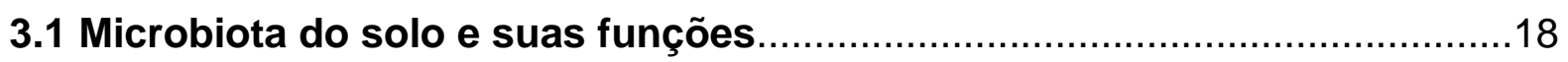

3.1.1 Ciclos do Carbono e Nitrogênio.............................................................19

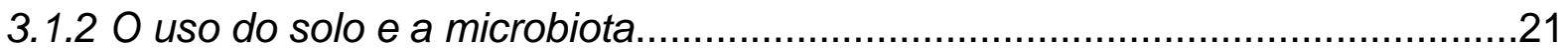

3.2 O desmatamento e o uso do solo na Amazônia.................................................

3.2.1 Uso do solo e emissão de gases do efeito estufa ........................................24

3.2.2 O uso do solo e a biodiversidade na Amazônia................................................25

3.3 Métodos moleculares para análise de genes funcionais............................27

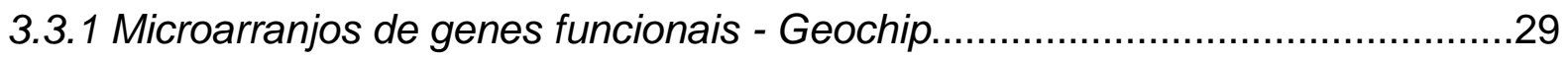

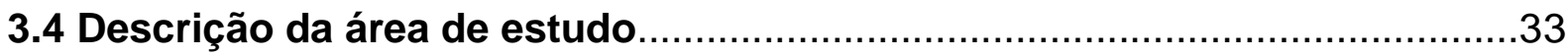

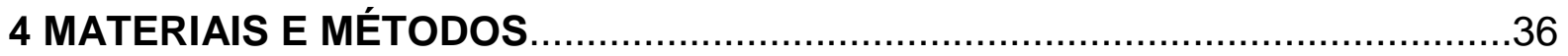

4.1 Amostragem .

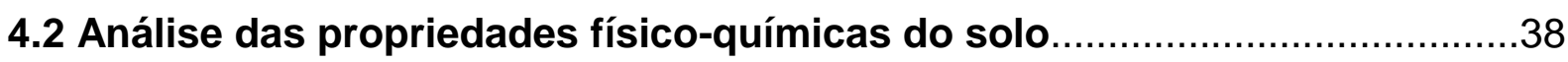

4.3 Obtenção do DNA genômico das amostras de solo.......................................38

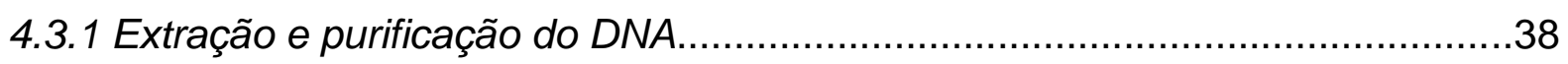

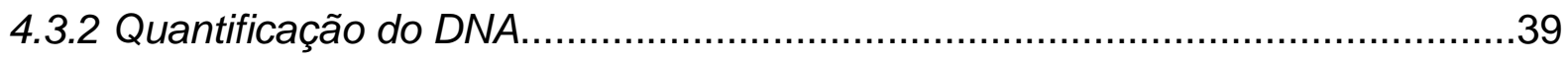

4.4 Técnica de microarranjo de DNA- Geochip.............................................

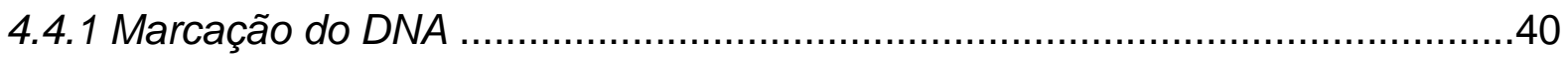

4.4.2 Pré-hibridização e hibridização....................................................................

4.4.3 Lavagem das lâminas............................................................................. 41

4.4.4 Escaneamento e processamento das imagens...........................................42

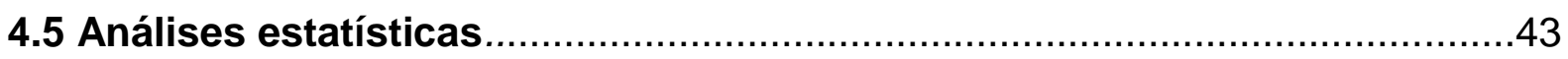

5 RESULTADOS

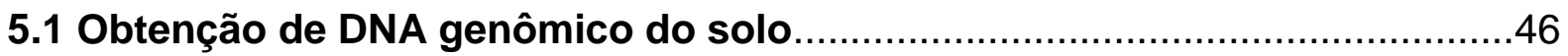

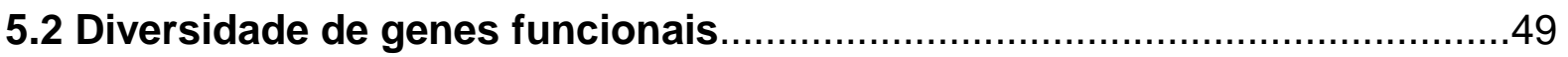

5.3 Estrutura funcional das comunidades microbianas do solo.......................54

5.3.1 Ordenação em escala multidimensional não métrica (NMDS) .........................54

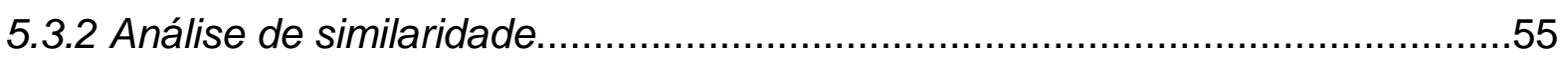

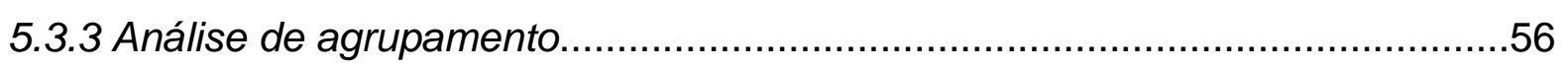


5.4 Influência de fatores ambientais sobre a estrutura funcional da comunidade

5.4.1 Quantificação dos fatores físico-químicos...

5.4.2 Correlações entre os fatores físico-químicos e a estrutura funcional da comunidade.

5.5 Correlação entre a distância espacial e distância Bray-Curtis nos sítios de amostragem.

5.6 Teste de associação de famílias de genes aos solos submetidos

a diferentes formas de uso.

6 DISCUSSÃO

6.1 Diversidade de genes funcionais em solos da Amazônia submetidos a diferentes formas de uso. .70

6.2 Estrutura funcional da comunidade microbiana em solos da

Amazônia submetidos a diferentes formas de uso.

6.3 Influência dos fatores ambientais sobre a estrutura funcional

da comunidade microbiana.

6.4 Influência da distância espacial sobre a diferença entre dois pontos de amostragem.

6.5 Associação de genes funcionais aos solos submetidos a diferentes formas de uso .78

6.5.1 Ciclo do Nitrogênio..

6.5.2 Ciclo do Carbono.

6.6 Acesso ao potencial funcional do solo da Amazônia empregando Geochip

6.7 Impacto do uso do solo sobre o potencial funcional em solos da

Amazônia.

7 CONCLUSÕES.

REFERÊNCIAS

ANEXO A. 


\section{INTRODUÇÃO}

A grande biodiversidade abrigada pela floresta Amazônica e a importância deste ecossistema para o ciclo do carbono global têm despertado interesse de cientistas do mundo inteiro. Este interesse é, em grande parte, destinado à compreensão dos impactos gerados pelo desmatamento acelerado e pela expansão da agropecuária nesta região (FEARNSIDE, 1999; GALFORD et al., 2011; DAVIDSON et al, 2012).

Recentemente, estudos sobre a microbiota do solo da Amazônia revelaram uma grande diversidade taxonômica, bem como uma susceptibilidade da estrutura de comunidades bacterianas frente aos impactos gerados pelo desmatamento e pelo manejo do solo (BORNEMAN; TRIPLETT, 1997; JESUS et al., 2009; CENCIANI et al., 2009). Comunidades microbianas do solo realizam funções essenciais para o ecossistema, como a ciclagem de nutrientes, e impactos que gerem alterações de sua estrutura podem se refletir em aspectos importantes, como a sustentabilidade e a fertilidade do solo e o balanço de gases do efeito estufa (ZHANG et al., 2007).

Diante da importância de compreender as respostas das comunidades microbianas do solo da Amazônia frente a mudanças em seu habitat, os aspectos ecológicos relacionados e as consequências para o ecossistema, o projeto que esta tese integra foi proposto. O projeto denominado de "Monitoramento da Microbiota da Floresta Amazônica" ("Amazon Rainforest Microbial Observatory" - ARMO) reuniu pesquisadores da Universidade de São Paulo, Michigan State University, University of Massachusetts at Amherst, University of Oregon e University of Texas at Arlington. Este projeto tem como objetivo caracterizar a microbiota do solo da Amazônia, submetidos a diferentes formas de uso, empregando uma variedade de técnicas e abordagens, e possui duas inovações principais em relação aos trabalhos desenvolvidos anteriormente na região. A primeira é a forma de amostragem, que além de contar com um grande número de replicatas, emprega um sistema em escala espacial, que reduz problemas relacionados à sub-amostragem e permite avaliar a distribuição espacial dos micro-organismos. A segunda é em relação aos métodos de análise empregados. Foi proposta a utilização de técnicas moleculares de alto rendimento, como sequenciamento de última geração e lâminas de microarranjo de DNA, que permitem a caracterização mais detalhada de 
comunidades complexas, como as do solo e suas funções, minimizando problemas de falta de cobertura.

O projeto ARMO foi estabelecido em uma fazenda de pecuária em Rondônia, Estado da Amazônia brasileira com maior porcentagem de área de floresta comprometida pelo desmatamento. As perguntas do projeto giram em torno de uma questão central, que visa entender as alterações causadas pelo desmatamento e formação de pastagens sobre a microbiota do solo, bem como a importância do crescimento da floresta secundária para a restauração dessas comunidades.

Dentro deste contexto, é de grande importância entender como as mudanças na estrutura da comunidade microbiana se refletem nas funções realizadas pela mesma. Estudos pretéritos realizados na mesma fazenda, avaliando a ciclagem de nutrientes frente ao sistema de uso do solo mencionado, apontaram alterações em processos importantes realizados pela microbiota (STEUDLER et al., 1996; NEILL et al., 1997; NEILL et al., 2005). Entretanto o potencial genético relacionado a essas e outras funções no solo da Amazônia ainda foi pouco explorado.

Diante disso, o presente estudo buscou avaliar o potencial funcional da microbiota de solos da Amazônia, acessando a diversidade de genes que codificam proteínas evolvidas em diversos processos metabólicos (genes funcionais). Os impactos do uso do solo foram avaliados empregando um modelo do sistema floresta - pastagem - floresta secundária. Nossa hipótese é de que, assim como verificado para a análise taxonômica, a estrutura funcional da comunidade é alterada com o estabelecimento de pastagem, pois a modificação de características do solo favoreceria a colonização por micro-organismos com genoma funcional adaptado às novas condições. Adicionalmente, o desenvolvimento da floresta secundária favoreceria o restabelecimento da comunidade encontrada na floresta primária.

Para caracterizar a diversidade de genes funcionais foi empregada uma técnica de microarranjo de DNA, denominada Geochip (HE et al., 2011), que permite avaliar o potencial funcional da comunidade, desde sua estrutura geral até diferenças em grupos específicos. Finalmente, neste estudo foi proposta a aplicação de um índice de associação para avaliar os impactos do uso do solo sobre processos funcionais de importância ecológica. 


\section{OBJETIVOS}

Para testar a hipótese descrita acima, os objetivos deste trabalho foram:

- Caracterizar a diversidade de genes funcionais em solos no sudoeste da Amazônia, empregando a técnica de microarranjo de DNA (Geochip);

- Avaliar os efeitos do desmatamento e do estabelecimento de pastagens sobre a diversidade e a estrutura funcional da comunidade microbiana do solo, e verificar se o tempo de uso da pastagem possui importância neste processo;

- Avaliar se uma área de floresta secundária possui diversidade e estrutura funcional da comunidade microbiana do solo semelhante à floresta primária;

- Investigar a correlação entre características do solo e a estrutura das comunidades;

- Propor e testar a utilização de um índice de associação, tradicionalmente empregado para espécies, para avaliar os impactos do uso do solo sobre famílias de genes funcionais relacionadas a processos dos ciclos do carbono e nitrogênio. 


\section{REVISÃO DE LITERATURA}

\subsection{Microbiota do solo e suas funções}

Comunidades microbianas do solo possuem elevada diversidade e complexidade. Estima-se que um grama de solo possa conter até $10^{9}$ células microbianas, representando mais de 10 mil genomas diferentes (TORSVIK; OVREAS, 2002). Funções essenciais para a manutenção do ecossistema são realizadas por micro-organismos, os quais são os principais condutores dos ciclos biogeoquímicos, possuem papel importante na fertilidade do solo e no fluxo de gases do efeito estufa, além de serem capazes de degradar uma variedade de compostos, incluindo poluentes de origem antrópica (LIANG et al., 2009; HE et al., 2011). Essa variedade de funções advém da grande diversidade metabólica existente entre os grupos microbianos, que podem utilizar diferentes fontes de carbono e de energia e colonizar ambientes com as mais diversas características.

Da mesma forma que as comunidades do solo atuam sobre o ambiente, controlando processos com sua atividade metabólica, a presença e abundância de grupos microbianos é influenciada por características ambientais, envolvendo fatores físicos, químicos e biológicos. Variações desses fatores promovem uma grande variedade de micro-habitats no solo possibilitando colonização por micro-organismos com os mais diferentes nichos (KURAMAE et al., 2012). Esta relação entre microbiota e ambiente gera várias questões com relação a processos, produtos, efeitos de impactos ambientais e consequências para o ecossistema.

A importância da diversidade da microbiota para a manutenção das funções do solo tem sido alvo de diferentes estudos (TORSVIK; OVREAS, 2002; COLEMAN; WHITMAN, 2005; FITTER et al., 2005). Trabalhos que avaliaram resistência (VAN ELSAS et al., 2012) e resiliência (FITTER et al., 2005) da comunidade frente a perturbações ambientais, destacaram a importância da sua biodiversidade. Entretanto esta é uma relação complexa, e é preciso conhecer os papeis desempenhados pelas espécies, bem como a redundância entre elas, para então compreender a relação entre biodiversidade e função (COLEMAN; WHITMAN, 2005). 


\subsubsection{Ciclos do Carbono e Nitrogênio}

Algumas das principais funções dos micro-organismos do solo estão ligadas aos ciclos biogeoquímicos, como por exemplo do carbono e do nitrogênio. Estes elementos são transportados pelo ecossistema, via reações bioquímicas que alteram sua forma e/ou estado de oxidação (MADSEN, 2008). Embora todos os seres vivos participem de alguma forma da ciclagem de nutrientes, muitas etapas são exclusivas dos micro-organismos. Algumas reações podem ser realizadas por diferentes grupos microbianos como, por exemplo, decomposição de compostos orgânicos, enquanto que outras são exclusivas de grupos especializados, como fixação de nitrogênio e nitrificação (SWIFT et al., 1998).

Processos de ciclagem de nutrientes promovem a interação entre táxons distintos, onde o produto do metabolismo de um micro-organismo é usado como substrato para outro (MADSEN, 2008). No ciclo do carbono, por exemplo, organismos autotróficos são capazes de fixar dióxido de carbono $\left(\mathrm{CO}_{2}\right)$, produzindo biomassa, por meio de diferentes vias metabólicas (SATO; ATOMI, 2010). O carbono orgânico pode então ser transferido entre organismos, possibilitando o crescimento de vários heterotróficos, os quais através do metabolismo respiratório ou fermentativo devolvem $\mathrm{CO}_{2}$ para a atmosfera. Em habitat anaeróbico, arqueias metanogênicas podem reduzir $\mathrm{CO}_{2}$, formando metano $\left(\mathrm{CH}_{4}\right)$, o qual é um potente gás do efeito estufa. O metano não pode ser utilizado por qualquer micro-organismo, e apenas grupos especializados, denominados metanotróficos, são capazes de oxidá-lo (MADSEN, 2008).

Uma variedade de reações e de grupos microbianos com diferentes metabolismos fazem parte do ciclo do nitrogênio. $O$ nitrogênio molecular $\left(N_{2}\right)$ pode ser utilizado apenas por grupos restritos de micro-organismos, chamados fixadores de nitrogênio. Neste processo, o $\mathrm{N}_{2}$ é reduzido a amônia $\left(\mathrm{NH}_{3}\right)$, que pode ser incorporada à biomassa. A maioria dos micro-organismos utilizam as formas inorgânicas amônio $\left(\mathrm{NH}_{4}^{+}\right)$, nitrito $\left(\mathrm{NO}_{2}^{-}\right)$e nitrato $\left(\mathrm{NO}_{3}{ }^{-}\right)$e compostos orgânicos como fonte de nitrogênio. Durante a mineralização, ocorre a liberação de $\mathrm{NH}_{4}{ }^{+}$de moléculas orgânicas. A oxidação de $\mathrm{NH}_{3}$ a $\mathrm{NO}_{3}{ }^{-}$é um processo denominado nitrificação, e é composto por duas etapas, realizadas por dois grupos de microorganismos distintos, os oxidadores de amônia e os oxidadores de nitrito. $\mathrm{NO}_{3}{ }^{-} \mathrm{e}$ $\mathrm{NO}_{2}^{-}$podem ser consumidos por desnitrificantes, que os utilizam como aceptor final 
de elétrons. Uma sequências de reações de redução realizadas por esses microorganismos culmina com a liberação de $\mathrm{N}_{2}$, passando por três intermediários. Dentre esses intermediários estão óxido nitroso $\left(\mathrm{N}_{2} \mathrm{O}\right)$ e óxido nítrico $(\mathrm{NO})$, os quais são considerados direta e indiretamente gases do efeito estufa, e podem escapar para a atmosfera (MADSEN, 2008). Alguns microrganismos nitrificantes também são capazes de produzir $\mathrm{NO}$ e $\mathrm{N}_{2} \mathrm{O}$, a partir da redução de $\mathrm{NO}_{2}{ }^{-}$, um processo que é favorecido pela redução do nível de oxigênio disponível (BOLLMANN; CONRAD, 1998). Adicionalmente, o $\mathrm{N}_{2} \mathrm{O}$ também pode ser produzido durante a nitrificação, por decomposição dos intermediários hidroxilamina $\left(\mathrm{NH}_{2} \mathrm{OH}\right)$ e $\mathrm{NO}_{2}^{-}(\mathrm{MADSEN}, 2008)$.

Uma das principais preocupações com relação aos ciclos do carbono e nitrogênio refere-se à produção de gases do efeito estufa e suas consequências para o aquecimento global. No último século, as concentrações atmosféricas de gases de ocorrência natural, como $\mathrm{CO}_{2}, \mathrm{CH}_{4}$ e $\mathrm{N}_{2} \mathrm{O}$, têm aumentado significativamente, em comparação com períodos anteriores. Este aumento tem sido atribuído a atividades antrópicas, como queima de combustíveis fósseis e uma variedade de práticas ligadas ao manejo de terras, incluindo alagamento de áreas, pecuária e queima de vegetação (MADSEN, 2008). Atividades biogênicas relacionadas à produção e ao consumo desses gases estão ligadas a ação de micro-organismos e a processos de ciclagem de nutrientes, e sofrem influência de características do solo, como porosidade, umidade e disponibilidade de oxigênio e nutrientes.

Além de aspectos ligados ao balanço de gases do efeito estufa, o funcionamento dos ciclos biogeoquímicos também é de relevância para agropecuária, pois possui grande importância para a manutenção da fertilidade do solo. Fixadores de nitrogênio, disponibilizam este elemento para as plantas, com as quais podem estabelecer associações simbióticas, como ocorre entre bactérias do gênero Rhizobium e plantas leguminosas. A nitrificação converte $\mathrm{NH}_{3}$ em $\mathrm{NO}_{3}$, forma que pode ser facilmente lixiviada em solos ácidos, reduzindo a disponibilidade de $\mathrm{N}$ para plantas. Além disso, o nitrato lixiviado pode causar a contaminação da água. $\mathrm{O}$ nitrogênio é geralmente o nutriente limitante e a disponibilidade natural de suas formas fixadas depende do balanço entre as atividades de fixação, nitrificação e desnitrificação. O emprego de fertilizantes com amônio, bem como a aplicação de inibidores da nitrificação são práticas adotadas na agricultura. Rotação de cultura com leguminosas, como a soja, também pode ajudar a prevenir a exaustão do 
nitrogênio do solo, e reduzir gastos com fertilizantes, devido à associação dessas plantas com fixadores de nitrogênio (ATLAS, 1997). Em adição às atividades relacionadas à ciclagem de $\mathrm{N}$, a própria biomassa microbiana contem quantidade considerável de nutrientes que podem ser utilizados pelas plantas. Além de representarem um estoque lábil de nutrientes, os micro-organismos podem também prevenir a lixiviação dos mesmos, através da sua imobilização (FEIGL et al., 1998).

\subsubsection{O uso do solo e a microbiota}

Apesar da importância dos micro-organismos do solo na realização de processos de interesse ambiental e agronômico, ainda não é bem estabelecido como mudanças em seu habitat podem gerar impacto sobre as comunidades e suas funções (BERTHRONG et al., 2009). Muitos trabalhos apontam a forma de uso do solo como um importante fator influenciando a microbiota (JESUS et al., 2009; TAKETANI; TSAI, 2010; NAVARRETE et al., 2011), porém os mecanismos envolvidos ainda são incertos (HE et al., 2012), e variações nas respostas são encontradas em diferentes locais, indicando importância de características inerentes ao ambiente.

Frequentemente, mudanças na cobertura vegetal e na forma de manejo são acompanhadas por alterações em características do solo como $\mathrm{pH}$, umidade e disponibilidade de nutrientes (KURAMAE et al., 2012). Estas características, por sua vez, já foram apontadas como importantes fatores influenciando as comunidades microbianas do solo (HANSEL et al., 2008; HE et al., 2012). Fatores físico-químicos, cobertura vegetal, uso do solo e tipo de solo parecem interagir de forma complexa guiando estrutura e função das comunidades.

Estrutura e diversidade taxonômica das comunidades microbianas são alguns dos parâmetros frequentemente alterados entre solos sob vegetação nativa e submetidos a manejo (JESUS et al., 2009; TAKETANI; TSAI, 2010; NAVARRETE et al., 2011). Além de buscar por fatores ambientais que guiam essas mudanças, uma pergunta relevante é se a alteração da comunidade é acompanhada por uma mudança fisiológica, ou se uma redundância funcional assegura que a comunidade permaneça funcionalmente semelhante à original. Quantificações de taxas de processos microbianos (p. ex., nitrificação e mineralização) ou de seus produtos ( $p$. ex. produção de gases), são formas práticas de verificar como impactos ambientais 
podem alterar a funcionalidade de uma comunidade (ALLISON; MARTINY, 2008). Outra forma de avaliar é estudando grupos microbianos específicos, que desempenham determinadas processos, ou através da diversidade funcional da comunidade, acessando seu genoma.

Compreender como grupos microbianos funcionais do solo respondem a alterações ambientais pode ser útil do ponto de vista agronômico, pois sua produtividade depende da ciclagem de nutrientes e mudanças no uso do solo podem alterar esse equilíbrio (FEIGL et al., 1998). Com relação à importância ambiental, são inúmeros os aspectos relevantes relacionados às respostas das comunidades microbianas do solo, como fluxo de gases do efeito estufa, capacidade de degradar poluentes, e a própria produtividade agrícola, que pode significar sustentabilidade do ecossistema.

\subsection{O desmatamento e o uso do solo na Amazônia}

Nas últimas décadas, a floresta Amazônica vem sendo seriamente ameaçada pelo desmatamento e pela expansão da agropecuária. Estima-se que quase $20 \%$ da floresta original já tenha sido perdida, além das áreas degradadas e em risco, devido à pressão antrópica (BARRETO et al., 2005).

Abrangendo uma área de mais de 4 milhões de quilômetros quadrados, a Amazônia brasileira compreende os estados do Acre, Amazonas, Amapá, Rondônia, Mato Grosso, Roraima, Pará, Maranhão e Tocantins. O mapa do desmatamento acumulado até 2010 na região mostra que os estados do Pará, Mato Grosso e Rondônia encontram-se em situação crítica (Figura 1). Estes fazem parte do chamado "arco do desmatamento", que compreende as áreas que sofrem maior pressão da ação antrópica (BARRETO et al., 2005).

O desmatamento intenso da Amazônia brasileira iniciou-se na década de 1970, quando grandes áreas de floresta nativa começaram a ser derrubadas, em decorrência de incentivos fiscais oferecidos pelo governo para o desenvolvimento da região (KRUSCHE et al., 2005). Desde 1988, o Instituto Nacional de Pesquisas Espaciais (INPE) vem monitorando as taxas anuais de desmatamento na região, que chegaram a atingir mais de $27 \mathrm{mil} \mathrm{Km}^{2}$, como em 2004. Entre agosto de 2010 e julho de 2011 foram desmatados mais de $6200 \mathrm{~km}^{2}$, e o total perdido desde 1988 é de quase 400 mil $\mathrm{Km}^{2}$. Segundo Fearnside (2005), as oscilações nas taxas de 
desmatamento desde 1970 são, em grande parte, explicadas por políticas de incentivo e períodos de recessão econômica.

Figura 1 - Desmatamento acumulado na Amazônia legal até 2010.

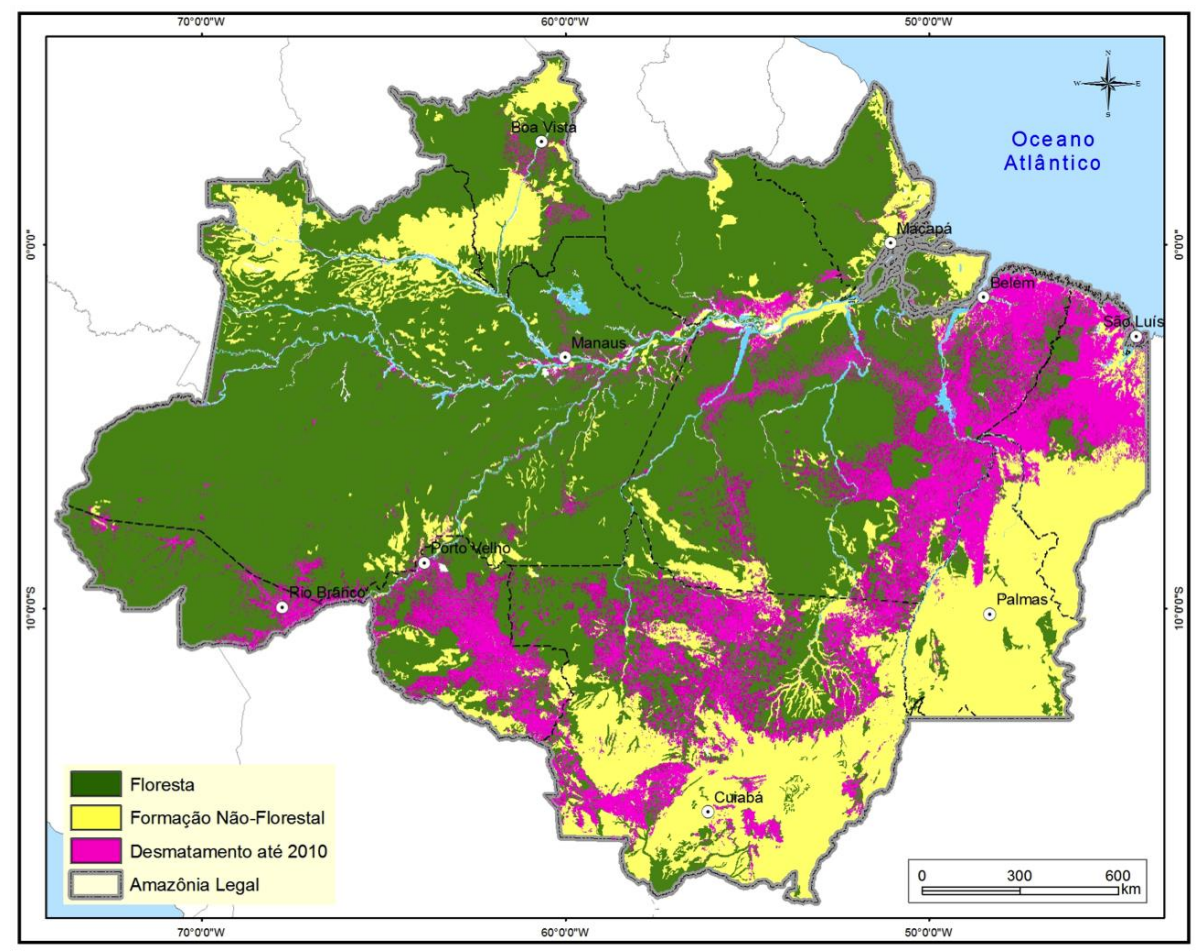

FONTE: Instituto Imazon (www.imazon.org.br).

Uma das principais causas do desmatamento na Amazônia brasileira é a formação de pastagens para pecuária (KRUSCHE et al., 2005), onde a maior parte é atribuída aos latifúndios, que buscam atender ao mercado interno e externo. A agricultura também vem crescendo nos últimos anos, sendo também responsável por uma parte expressiva das áreas derrubadas (FEARNSIDE, 2005; DAVIDSON et al., 2012). Uma prática comum no estabelecimento de pastagens é o sistema de corte e queima, onde as árvores de valor comercial são retiradas e o fogo é usado para limpar a área e para controlar as ervas daninhas periodicamente.

Diversos prejuízos do desmatamento para o ecossistema já são bem conhecidos, sendo o impacto sobre a biodiversidade um dos mais notáveis. Além disso, características do solo também são alteradas, devido a erosão, compactação e exaustão de nutrientes, verificada na queda da produtividade no decorrer dos anos. A baixa produtividade de pastagens na Amazônia gera preocupações do ponto 
de vista ecológico, pois frequentemente acarreta em abandono das mesmas e busca por novas áreas, o que contribui para o aumento da taxa do desmatamento na região (MULLER et al., 2004).

A substituição da floresta por pastagem causa uma redução da absorção da radiação solar e pode também afetar o clima e o regime hidrológico, alterando taxas de precipitação, tanto em escala local, quanto regional (FEARNSIDE, 2005; DAVIDSON et al., 2012). O uso do fogo gera várias consequências, como perda de nitrogênio do solo, alterações dos estoques de carbono, modificação da biomassa microbiana, além de aumentar as partículas de aerossol e concentrações de gases do efeito estufa na atmosfera (FEIGL et al., 1998; DAVIDSON et al., 2012).

\subsubsection{Uso do solo e emissão de gases do efeito estufa}

O desmatamento e o uso do solo em áreas tropicais estão entre os principais fatores contribuindo para o aumento das concentrações atmosféricas de gases do efeito estufa (GEE) (PALM, et al., 2002). A floresta Amazônica tem sido apontada como importante no ciclo global do carbono (GALFORD et al., 2011), e avaliações a longo prazo sugerem que esta age como sorvedouro, acumulando carbono. $O$ desmatamento e o uso do solo na região promovem a liberação de $\mathrm{C}$, sendo grande parte atribuída às queimadas (FEIGL et al., 1998; GALFORD et al., 2011; DAVIDSON et al., 2012). De acordo com Kauffman et al. (1998), ao considerar extensa área, as queimadas na Amazônia constituem uma fonte significante de C atmosférico. A grande quantidade de carbono estocada em forma de biomassa na floresta gera preocupações quanto às emissões de carbono em potencial para o futuro.

Estudos sobre o gás metano mostram que as áreas alagadas são responsáveis pela maior parte da emissão na Amazônia. Entretanto, o fluxo deste gás em áreas de floresta não inundáveis e os impactos do uso do solo podem ter importância no balanço final do ecossistema. Embora Do Carmo et al. (2006) tenham apontado a floresta nativa como fonte de metano, muitos autores já relataram um fluxo negativo, indicando que a área sob vegetação nativa funciona como um sorvedouro (STEUDLER et al., 1996; VERCHOT et al., 2000; FERNANDES et al., 2002). O efeito da conversão da floresta a pastagem já foi verificado em várias regiões da bacia amazônica e revelaram que a pastagem 
consome metano em menores taxas que a floresta, ou mesmo agem como fonte do gás (STEUDLER et al., 1996; VERCHOT et al., 2000; FERNANDES et al., 2002). Variações nos resultados obtidos sugerem que os principais fatores ambientais guiando as taxas observadas são a umidade e a porosidade do solo, o que pode ter uma grande variação entre ambientes e entre estações do ano. Adicionalmente, ao contabilizar $\circ \mathrm{CH}_{4}$ emitido durante as queimadas, o efeito da formação de pastagens é ainda mais evidente (STEUDLER et al., 1996).

Já está bem estabelecido que a principal fonte de $\mathrm{N}_{2} \mathrm{O}$ na Amazônia são as áreas de floresta nativa, mas sabe-se que pastagens recém formadas apresentam um pico de emissão deste gás (NEILL et al., 2005). Isso deve ser levado em consideração em locais onde a perda da produtividade ocorre de forma rápida e novas pastagens são frequentemente formadas.

\subsubsection{O uso do solo e a biodiversidade na Amazônia}

Segundo Sala et al. (2000) e Chapin et al. (2000), mudanças na forma de uso do solo estão entre os principais causadores de impactos na biodiversidade, principalmente em ecossistemas tropicais.

A Amazônia é conhecida por sua grande biodiversidade, a qual pode ser exemplificada com mais de 40000 espécies de plantas, 1200 espécies de pássaros e 3000 espécies de peixes já catalogadas (DA SILVA; RYLANDS; DA FONSECA, 2005). Embora algumas estimativas já tenham sido feitas com relação ao impacto do desmatamento sobre a perda de biodiversidade (VIEIRA; SILVA; TOLEDO, 2005), estes números ainda são incertos, mas calcula-se um grande impacto, dada a alta densidade de fauna e flora. Além do impacto direto na diversidade de plantas, a retirada da vegetação nativa causa a perda de habitats para a fauna. A fragmentação da floresta altera o microclima, causando mortalidade de plantas e impactos sobre a variabilidade da fauna remanescente e sobre suas relações ecológicas. De acordo com Fearnside (1999), o desmatamento de áreas tropicais gera um grande impacto sobre a biodiversidade, pois muitas espécies são endêmicas a áreas restritas e são incapazes de resistir às mudanças drásticas.

Embora inúmeros estudos já tenham sido realizados com foco na diversidade de macro-organismos, catalogando, entendendo as relações ecológicas e as respostas frente a pressões ambientais, apenas recentemente esforços têm sido 
feitos para compreender a diversidade microbiana. $O$ avanço do desmatamento gerou questões sobre o comportamento da microbiota do solo frente às práticas de manejo adotadas na agropecuária. Os pioneiros a avaliar este sistema na Amazônia foram Borneman e Triplett (1977), que alertaram para a diversidade encontrada e para as diferenças entre as populações de floresta e pastagem. Desde então, outros trabalhos foram desenvolvidos, com maiores esforços de amostragem e aplicando diferentes técnicas para avaliar a diversidade taxonômica em solos da Amazônia brasileira (YIN et al., 2000; KIM et al., 2007; CENCIANI et al., 2009; JESUS et al., 2009; TAKETANI; TSAI, 2010). Recentemente, Cenciani et al. (2009), observaram diferenças entre comunidades bacterianas do solo de floresta primária, pastagem e floresta secundária. Em outro trabalho, Jesus et al (2009), demonstraram que as comunidades de solos de pastagem e de plantações possuem estrutura taxonômica diferente da floresta primária e que a floresta secundária tende a recuperar o perfil original.

Diante da constatação da susceptibilidade da microbiota frente aos impactos causados pelo uso do solo, cabe questionar se as alterações observadas na estrutura taxonômica são acompanhadas por alterações na estrutura funcional. Estudos realizados na região, quantificando processos relacionados à atividade microbiana, como ciclagem de nutrientes e fluxo de gases indicam que pelo menos algumas funções têm suas taxas alteradas (STEUDLER et al., 1996; NEILL et al., 1997; NEILL et al., 2005; CENCIANI et al., 2009). Análises do genoma funcional dessas comunidades podem contribuir para o entendimento da relação entre estrutura e função e para avaliar se as mudanças fisiológicas observadas estão relacionadas a alterações na comunidade microbiana funcional.

Apenas alguns estudos realizados na região tiveram como foco respostas de grupos funcionais específicos. Taketani e Tsai (2010) demonstraram que comunidades de arqueias oxidadoras de amônia são alteradas pelo uso do solo. Yin et al. (2000) observaram que a diversidade de micro-oganismos com redundância funcional, relacionada à degradação de compostos, aumenta com o reestabelecimento de comunidades vegetais. Lammel (2011) demonstrou alterações na abundância de gentes relacionados ao fluxo de gases do efeito estufa em solos submetidos a diferentes formas de manejo. 


\subsection{Métodos moleculares para análise de genes funcionais}

O desenvolvimento das técnicas moleculares para análises de ácidos nucléicos no século passado possibilitou o acesso à diversidade microbiana do solo, revelando que esta é extremamente maior do que pode ser avaliado por técnicas de cultivo. Desde então, foi possível empregar marcadores moleculares para estudar composição, estrutura e função de comunidades microbianas, embora menos de $1 \%$ já tenha sido cultivado (HE et al., 2008). Grande parte dos estudos utilizam marcadores filogenéticos, como genes 16S rRNA de procariotos e 18S rRNA de eucariotos, para avaliar a diversidade taxonômica de ambientes. Um dos desafios dos últimos anos tem sido compreender as funções relacionadas à essa diversidade.

Apesar da importância de estudos de diversidade e estrutura das comunidades, avaliando marcadores filogenéticos, como o gene $16 \mathrm{~S}$ rRNA, pouco pode ser concluído a respeito das funções realizadas pelos microrganismos presentes a partir desses trabalhos. Isso se deve ao limitado conhecimento acerca do potencial metabólico dos micro-organismos. Além disso, apesar de algumas funções serem restritas a determinados táxons, outras são amplamente distribuídas pelos diferentes grupos taxonômicos (MORALES; COSART; HOLBEN, 2010; HE et al., 2011). Uma forma de contornar este problema é trabalhar diretamente com genes que codificam enzimas de interesse (HE et al., 2008; ENWALL et al., 2010). Estudos da diversidade de genes funcionais revelam a diversidade metabólica da comunidade, ou seja, as funções que podem estar sendo realizadas pelos microorganismos presentes (HE et al., 2011). Adicionalmente, a abundância de genes funcionais tem sido considerada uma forma de prever o potencial para realização de funções relacionadas àqueles genes em um ambiente (MORALES; COSART; HOLBEN, 2010).

Um grande número de métodos, com diferentes abordagens e poderes de resolução, já foram desenvolvidos para estudar genes funcionais em amostras ambientais. Muitos são baseados em Reação em cadeia da polimerase ("Polymerase Chain Reaction"- PCR) e empregam iniciadores específicos para os genes de interesse. Para avaliar a diversidade do gene no ambiente, bibliotecas genômicas a partir de sequências de genes provenientes de diferentes organismos podem ser construídas (GABRIEL, 2010). Outras técnicas avaliam o perfil da comunidade, sem necessariamente acessar diretamente as sequências dos genes. 
Dentre essas estão a análise do polimorfismo no comprimento de fragmentos de restrição terminal ("Terminal Restriction Fragment Length Polymorphism" - TRFLP) e Eletroforese em gel com gradiente de desnaturação ("Denaturing Gradient Gel Electrophoresis" - DGGE). Ambas separam fragmentos de DNA de acordo com características de sua sequência e são eficientes para mostrar variabilidade dentro da comunidade e fazer comparações entre amostras (THIES, 2007; GABRIEL, 2010).

A PCR em tempo real é um grande avanço para análises quantitativas. Grupos taxonômicos ou funcionais específicos podem ser monitorados, e pequenas variações no número de cópias dos genes flanqueados são identificadas. Embora não permita acessar a diversidade presente no ambiente, ela é uma ferramenta de grande utilidade para avaliar grupos específicos e suas alterações sob diferentes condições (MORALES; COSART; HOLBEN, 2010).

Outros métodos não requerem uma etapa de amplificação por PCR. Algumas técnicas de hibridização empregam sondas de DNA de sequência conhecida, marcadas com corantes fluorescentes, para encontrar genes de interesse. Estas podem ser utilizadas para rastrear os genes diretamente nas amostras ambientais, sem a necessidade de purificar o DNA, como é o caso da hibridização fluorescente in situ ("Fluorescence in situ hybridization" - FISH) (BOTTARI et al., 2006).

As técnicas citadas acima baseiam-se na investigação de apenas um gene. Evidentemente, análises de diferentes genes podem ser realizadas e os dados comparados, porém, esforços independentes devem ser feitos para cada um deles. Em trabalhos que buscam avaliar um ou poucos genes, estes métodos são eficientes para responder diversas questões. Entretanto, a análise de um grande número de genes dispenderia muito tempo e recursos.

Recentemente, trabalhos que buscam avaliar a diversidade taxonômica ou funcional de ambientes complexos, como o solo, têm investido em análises em grande escala, empregando técnicas de alto rendimento ("high throughput"). Estas incluem os sequenciamentos de nova geração (ROESCH et al., 2007), que permitem avaliar milhares de sequências em amostras ambientais, e as lâminas de microarranjo de DNA que possuem uma variedade de sondas para análise da diversidade taxonômica, do genoma funcional ou transcricional (ZHOU, 2003). 


\subsubsection{Microarranjos de genes funcionais - Geochip}

Os microarranjos são considerados potentes ferramentas para caracterizar comunidades microbianas e suas funções (TARONCHER-OLDENBURG et al., 2003). Esta tecnologia, que é tradicionalmente empregada para análise de expressão gênica, caracterização de doenças e detecção de mutações, tem sido aplicada com sucesso para estudos ambientais (ZHOU, 2003; DENG et al., 2008).

O potencial dessa técnica para análises ambientais foi destacado quando Guschin et al. (1997) desenvolveram um microarranjo de DNA para análise de grupos de bactérias nitrificantes, baseado em sequências de 16S rRNA. Desde então diversos trabalhos têm demonstrado suas vantagens e aplicabilidade. Os microarranjos podem caracterizar uma comunidade microbiana de forma robusta, abrangente e quantitativa, além de ser uma técnica rápida e menos dispendiosa, ao considerar a grande quantidade de dados gerada (HE et al., 2011).

Os arranjos de genes funcionais empregam sondas de DNA para genes que codificam para enzimas chave envolvidas em processos microbianos e permitem a avaliação da estrutura e do potencial funcional da comunidade (ZHOU, 2003). Alguns microarranjos genes funcionais já foram desenhados para avaliar genes dos ciclo do nitrogênio (GUSCHIN et al., 1997; WU et al., 2001; TARONCHEROLDENBURG et al., 2003), genes relacionados ao metabolismo do metano (BODROSSY et al., 2003), e resistência a antibióticos (CALL et al., 2003).

O grupo de pesquisa do Dr. Jizhong Zhou, do "Institute for Environmental Genomics" desenvolveu um microarranjo de genes funcionais, denominado Geochip, que permite a avaliação da diversidade e estrutura funcional de um ambiente, considerando não apenas um, mas vários grupos de genes funcionais, relacionados a diferentes processos microbianos. A técnica consiste no emprego de sondas de oligonucleotídeos de 50 pares de base específicas para genes de importância ambiental (HE et al., 2011).

O primeiro Geochip foi desenvolvido com 763 genes relacionados a processos do ciclo do nitrogênio, oxidação de metano e redução de sulfito (TIQUIA et al., 2004). Em seguida foi elaborado um arranjo para genes envolvidos em processos de biodegradação e resistência a metais (RHEE et al. 2004). O Geochip 2.0, com mais de 24 mil sondas, adicionou outros grupos funcionais, além de melhorar aspectos de especificidade e sensibilidade (HE et al., 2007). A terceira 
geração (Geochip 3.0) contém aproximadamente 28 mil sondas para 292 famílias de genes (HE et al., 2010a). Outras características foram adquiridas nessa versão, como emprego do oligonucleotídeo de referência padrão, para realizar processos de normalização e para permitir a comparação entre lâminas.

Em sua quarta geração de desenvolvimento, o Geochip 4.0 contém 83992 sondas, desenhadas para 410 famílias de genes funcionais, ligados a processos dos ciclos biogeoquímicos do carbono, nitrogênio, fósforo e enxofre, além de genes relacionados a resistência a metais, degradação de contaminantes orgânicos, resistência a antibióticos, genes de bacteriófagos, resposta a estresse e fatores de virulência. $O$ marcador filogenético gyrB também foi incluído na última versão do Geochip (Tabela 1).

A elaboração e construção da lâmina do Geochip passa por um processo com muitas etapas, iniciando-se pela seleção dos genes. Estes devem ser diretamente envolvidos em processos metabólicos de interesse, e quando disponível codificar a subunidade ativa da enzima (HE et al., 2011). A escolha das sequências para as sondas é realizada pelo "Geochip design pipeline". Para cada gene funcional de interesse, um conjunto de palavras-chave é submetido ao banco de dados de proteínas do GenBank (http://www.ncbi.nlm.nih.gov/protein). Todas as sequências de aminoácidos recuperadas são verificadas empregando o programa HMMER 2.3.2 (EDDY, 1998) e, após a confirmação das proteínas, estas são submetidas novamente ao GenBank para obter as sequências de nucleotídeos a serem usadas nas sondas (HE et al., 2010a). O desenho das sondas selecionadas é feito empregando-se o programa "CommOligo" (LI; HE; ZHOU, 2005). A especificidade de cada sonda é então verificada, a qual deve cumprir os seguintes requisitos, ao ser testada contra sequências não-alvo do GenBank: máxima similaridade de sequência $<90 \%$; comprimento máximo de extensão com identidade <20 bases; e energia livre $>-35 \mathrm{Kcal} / \mathrm{mol}$. Além disso, deve ter $>96 \%$ de identidade e $>35$ bases de bases comprimento máximo com extensão e $<-60 \mathrm{Kcal} / \mathrm{mol}$ de energia livre com sequências do grupo alvo. Em seguida, as sondas que atendem aos parâmetros de especificidade são sintetizadas diretamente na superfície da lâmina (HE et al., 2010a). 
Tabela 1 - Processos funcionais presentes na lâmina do Geochip 4.0.

\begin{tabular}{|c|c|c|c|}
\hline $\begin{array}{l}\text { Grupo de Processos } \\
\text { funcionais }\end{array}$ & $\begin{array}{l}\text { Processo } \\
\text { funcional }\end{array}$ & $\begin{array}{l}N^{\circ} \text { famílias } \\
\text { de genes }^{a}\end{array}$ & $\begin{array}{l}N^{\circ} \text { sondas } \\
\text { de genes }\end{array}$ \\
\hline \multirow[t]{4}{*}{ Ciclo do Carbono } & Degradação de Carbono & 33 & 9033 \\
\hline & Fixação de Carbono & 5 & 1762 \\
\hline & Oxidação de Metano & 2 & 240 \\
\hline & Produção Metano & 1 & 267 \\
\hline \multirow[t]{2}{*}{ Ciclo do Enxofre } & Oxidação de Enxofre & 1 & 468 \\
\hline & Redução N dissim & 5 & 2786 \\
\hline Ciclo do Fósforo & Utilização de Fósforo & 3 & 1378 \\
\hline \multirow{7}{*}{ Ciclo do Nitrogênio } & Amonificação & 2 & 999 \\
\hline & Anammox & 1 & 49 \\
\hline & Desnitrificação & 5 & 2654 \\
\hline & Fixação de Nitrogênio & 1 & 1224 \\
\hline & Nitrificação & 2 & 1443 \\
\hline & Redução N assim & 4 & 533 \\
\hline & Redução N dissim & 2 & 650 \\
\hline \multicolumn{2}{|c|}{ Degradação de compostos orgânicos } & 184 & 17919 \\
\hline \multicolumn{2}{|l|}{ Estresse } & 45 & 21574 \\
\hline \multicolumn{2}{|l|}{ Genes de bacteriófagos } & 40 & 1100 \\
\hline \multicolumn{2}{|c|}{ Marcador filogenético gyrB } & 1 & 2390 \\
\hline \multicolumn{2}{|l|}{ Processos energéticos } & 4 & 862 \\
\hline \multicolumn{2}{|c|}{ Resistência a antibióticos } & 11 & 3349 \\
\hline \multicolumn{2}{|c|}{ Resistência a metais } & 44 & 9478 \\
\hline \multicolumn{2}{|l|}{ Virulência } & 13 & 3732 \\
\hline
\end{tabular}

Ensaios de especificidade realizados por Liebich et al. (2006), empregando produtos de PCR, mostraram uma forte correlação positiva entre a similaridade da sonda-sequência alvo e a porcentagem de sondas hibridizadas. Os autores verificaram que o emprego combinado dos três parâmetros descritos acima para desenho das sondas (similaridade, comprimento máximo de extensão com identidade e energia livre) oferece uma alta especificidade e a capacidade de diferenciação entre sequências com alto grau de similaridade $(>90 \%)$. A especificidade também foi checada utilizando sequências sintetizadas e DNA genômico. O número de falsos positivos foi em torno de apenas 0,004 a 0,025\% (HE et al., 2007; HE et al., 2010a). Além dos critérios seguidos para desenho das sondas, parâmetros utilizados durante a hibridização também interferem na 
especificidade, como a concentração de formamida e a temperatura escolhida (HE et al., 2011).

O limite de detecção da técnica é de grande importância, considerando-se que muitos genes podem estar presentes no ambiente em baixíssima quantidade. Algumas estratégias melhoram a sensibilidade, como aumento do comprimento e da concentração das sondas (RELOGIO et al., 2002), redução do volume de

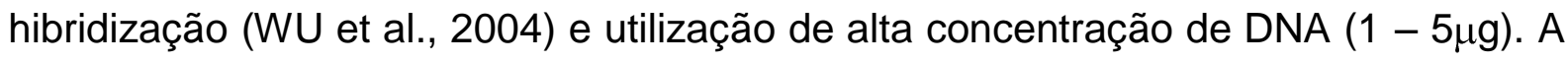
inclusão de novas estratégias para aumento da sensibilidade é sempre acompanhada de um processo cauteloso de padronização, para que não gere redução da especificidade da técnica.

Uma outra característica do Geochip é seu poder quantitativo, sendo a intensidade de sinal de cada sonda proporcional à abundância do gene na amostra. Testes de padronização mostram uma relação linear entre a concentração do DNA alvo e a intensidade de sinal para culturas pura e DNA ambiental (TIQUIA et al., 2004; WU et al., 2006). Estudos com DNA ambiental mostraram correlação entre valores obtidos em PCR quantitativo e intensidade de sinal no Geochip (HE et al., 2010b).

O Geochip tem sido empregado com sucesso para caracterizar a diversidade de genes funcionais em solo (YERGEAU, et al., 2007; HE et al., 2010b; XIONG et al., 2010), ambientes aquáticos (VAN NOSTRAND et al., 2009; WALDRON et al., 2009) e marinhos (WU et al., 2008; KLMES et al., 2010) e extremos (WANG et al., 2009), e tem sido apontado como uma valiosa ferramenta para avaliar impactos ambientais sobre comunidades funcionais (ZHANG et al., 2007; LIANG et al., 2009; REEVE et al., 2010).

O emprego do Geochip para avaliar ambientes ainda pouco conhecidos quanto à diversidade funcional, como é o caso do solo da Amazônia, pode revelar sua estrutura e potencial funcional, e ajudar a compreender os impactos causados pelo uso do solo. 


\subsection{Descrição da área de estudo}

A área de estudo foi a Fazenda Nova Vida, que compreende 22 mil hectares no município de Ariquemes -RO, a $250 \mathrm{Km}$ ao sul da capital Porto Velho (Figura 3). O clima local é classificado como tropical chuvoso (Aw - Classificação de Kopper), com precipitação anual de $2200 \mathrm{~mm}$ e média anual de temperatura de $25{ }^{\circ} \mathrm{C}$ (BASTO; DINIZ, 1982). Durante o verão, também chamado de estação chuvosa, que se estende de outubro a abril, a umidade relativa do ar varia de 80 a $90 \%$. A vegetação típica é floresta tropical úmida e o tipo de solo predominante é o Argissolo (JACOMINE, 2006).

Figura 3 - Mapa com a localização da Fazenda Nova Vida (seta na figura da ampliação do estado de Rondônia, à direita).

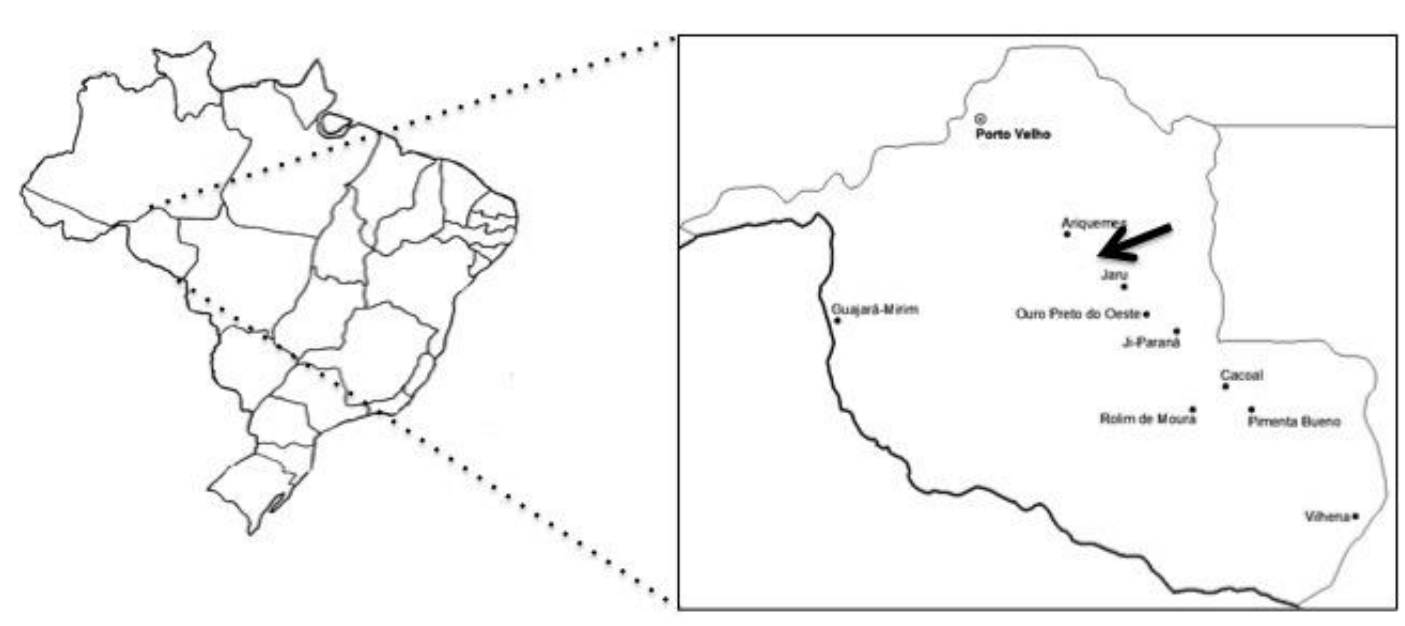

A principal atividade da fazenda é a pecuária extensiva. As pastagens são estabelecidas pelo sistema de corte e queima e posterior plantio das gramíneas dos gêneros Brachiaria, Panicum e/ou Urochloa, não sendo empregados fertilizantes químicos ou práticas agrícolas mecanizadas. As ervas daninhas são controladas periodicamente com fogo e quando as pastagens são consideradas improdutivas, estas são abandonadas, deixando crescer a Floresta Secundária. A Figura 4 mostra exemplos de áreas de floresta primária $(A)$, pastagem $(B)$ e floresta secundária $(C)$. 
Figura 4 -Fazenda Nova Vida - Rondônia. A) vista externa de uma floresta primária, que já possui uma estrada de acesso. B) pastagem em uso. C) floresta secundária.

A)

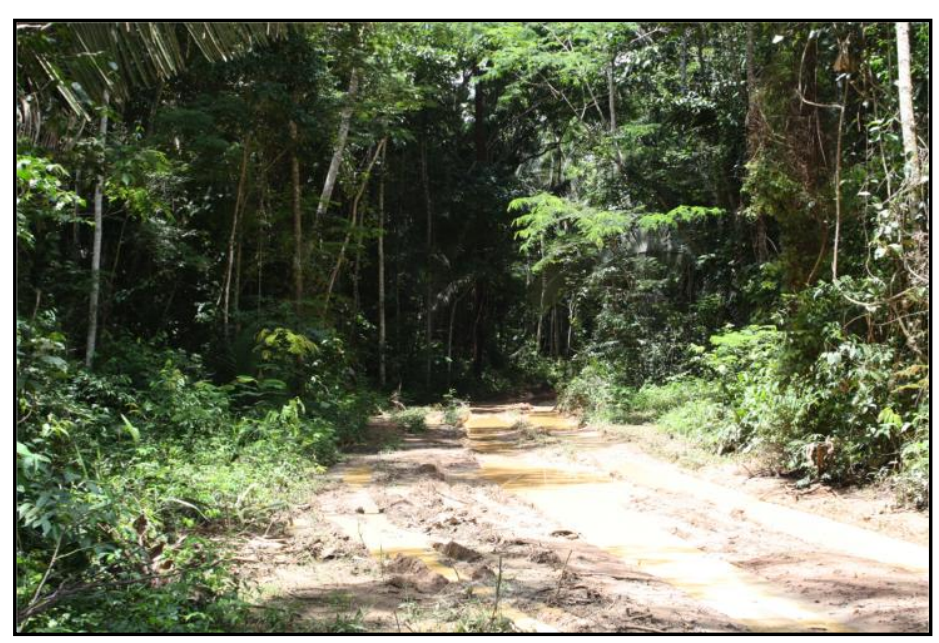

B)

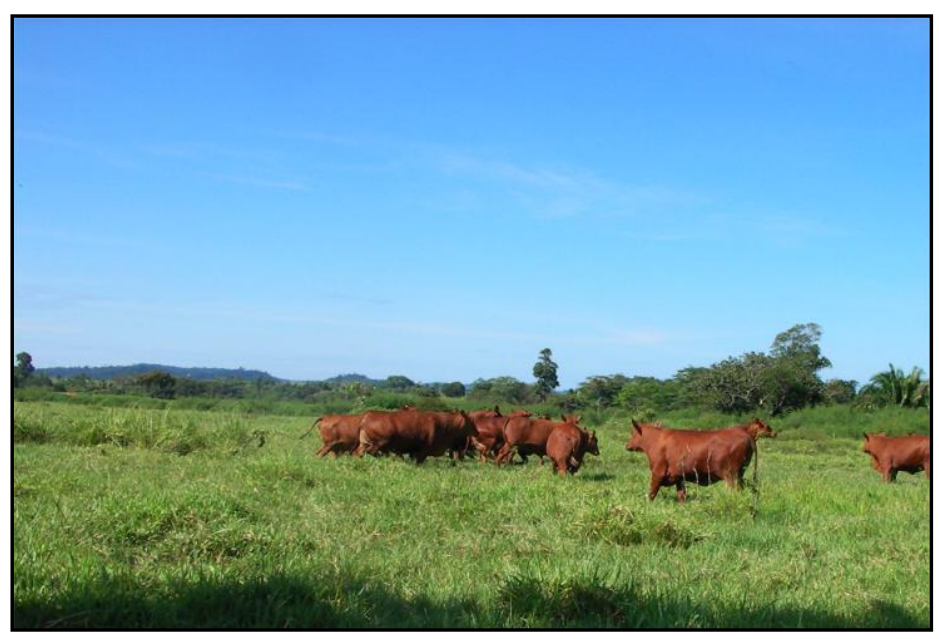

C)

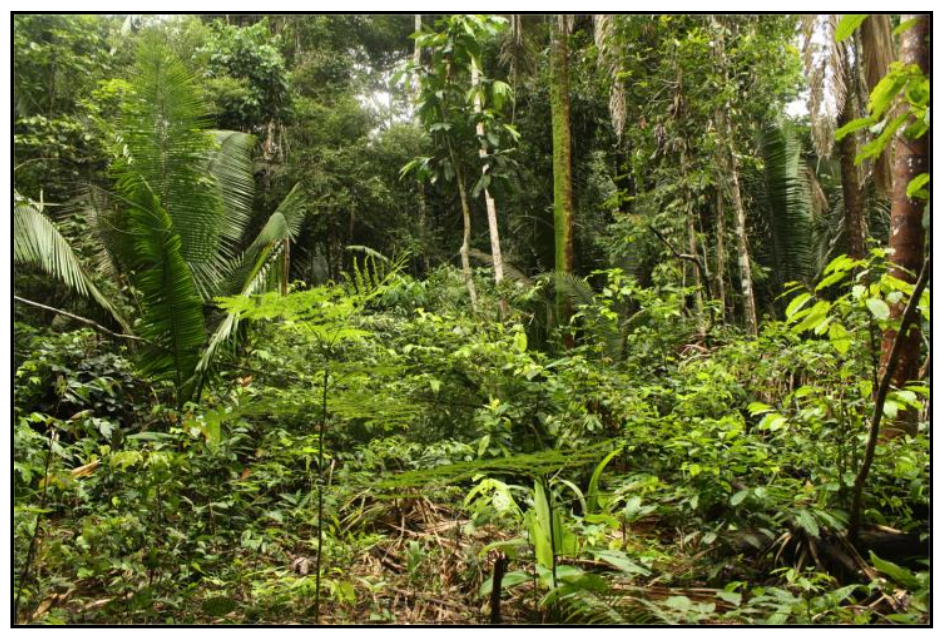

FONTE: gentilmente cedido por Rebecca Mueller e Kyunghwa Baek. 
Rondônia é o Estado brasileiro com maior perda da sua área de floresta amazônica (28.5\%). A Fazenda Nova Vida foi escolhida por ser considerada representativa do sistema de uso do solo na região, onde são encontrados mosaicos de remanescentes de floresta primária, intercaladas por pastagens criadas em diferentes anos, áreas de cultivo e florestas secundárias em diferentes estágios de recuperação. Além disso, a fazenda é um centro de pesquisa com estrutura de laboratório para processamento de amostras, e faz parte do Programa de Grande Escala da Biosfera-Atmosfera da Amazônia ("Large Scale Bioshpere-Atmosphere Experiment in Amazon - LBA; www.lbaeco.org/lbaeco/). Esta é uma das áreas mais estudadas na Amazônia, quanto aos impactos que o desmatamento e manejo do solo geram ao ecossistema. Existe uma grande quantidade de dados na literatura sobre o local, principalmente em relação às características do solo e as mudanças sofridas de acordo com a forma de manejo. Dentre as análises já realizadas estão características físico-químicas (DE MORAES et al., 1996), processos do ciclo do carbono e nitrogênio (STEUDLER et al., 1996; NEILL et al., 1997), biomassa e diversidade microbiana (CENCIANI et al., 2009), além de estudos de monitoramento de fluxos de gases do efeito estufa (FERNANDES et al., 2002; NEILL et al., 2005). Dados de processos microbianos do local puderam ser utilizados para comparação com os resultados de genes funcionais do presente trabalho. 


\section{MATERIAIS E MÉTODOS}

\subsection{Amostragem}

A coleta das amostras de solo na Fazenda Nova Vida foi realizada durante a estação chuvosa, em março de 2010. Para avaliar os impactos do uso do solo sobre a diversidade e estrutura funcional da comunidade microbiana, foram selecionados cinco sítios de amostragem (Figura 5A): uma floresta primária; três pastagens estabelecidas em diferentes anos (1911, 1972 e 2004), e que ainda são utilizadas como pastagem; e uma floresta secundária, que foi usada como pastagem até 1997, quando foi abandonada, e a vegetação secundária está se estabelecendo desde então. Todos os sítios eram, anteriormente à intervenção antrópica, caracterizados como floresta tropical úmida.

No momento da coleta, as idades das pastagens eram, respectivamente: 6 , 38 e 99 anos, e portanto serão aqui designadas por P6, P38 e P99, respectivamente. Serão usadas também as abreviações "F" para floresta primária e "S" para floresta secundária.

O solo da pastagem P99 possui diferentes características, comparando com os demais, o que se deve a uma diferente composição mineral (DE MORAES et al., 1996; HERPIN et al., 2002). Por este motivo, esta pastagem não será considerada parte da cronosequência, porém será incluída em todas as análises para fins de comparação.

Em cada um dos cinco sítios foi utilizado um sistema de amostragem, desenhado pelo Prof. Dr. Brendan Bohannan, da "University of Oregon", que consiste em um quadrante de $100 \mathrm{~m}^{2}$, composto de 12 pontos de coleta, com distâncias variando de 0,1 a $100 \mathrm{~m}$ (Figura 5B). O solo foi coletado de 0 a $10 \mathrm{~cm}$ de profundidade, utilizando cilindros de tamanho padronizado, homogeneizado e subdividido. $\mathrm{O}$ solo a ser utilizado em análises moleculares foi peneirado $(2 \mathrm{~mm})$ e armazenado a $-80^{\circ} \mathrm{C}$, e o solo para análises físico-químicas foi armazenado a $4{ }^{\circ} \mathrm{C}$. 
Figura 5 - Esquema de coleta de amostras de solo. A) Imagem de satélite da Fazenda Nova Vida, com a localização dos cinco sítios de amostragem. B) Desenho do quadrante de $100 \mathrm{~m}^{2}$ contendo 12 pontos de coleta (círculos). A001, A01, A1, A10, A100, B1, ... C100: pontos de coleta de cada sítio.

A)

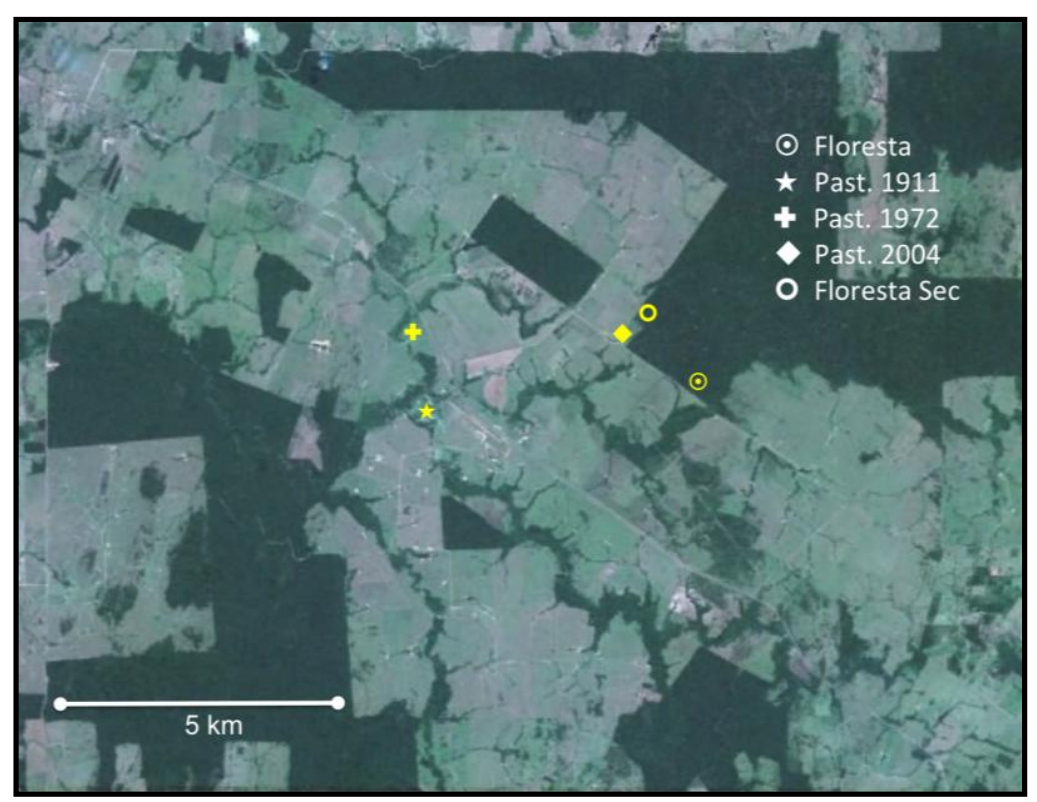

B)

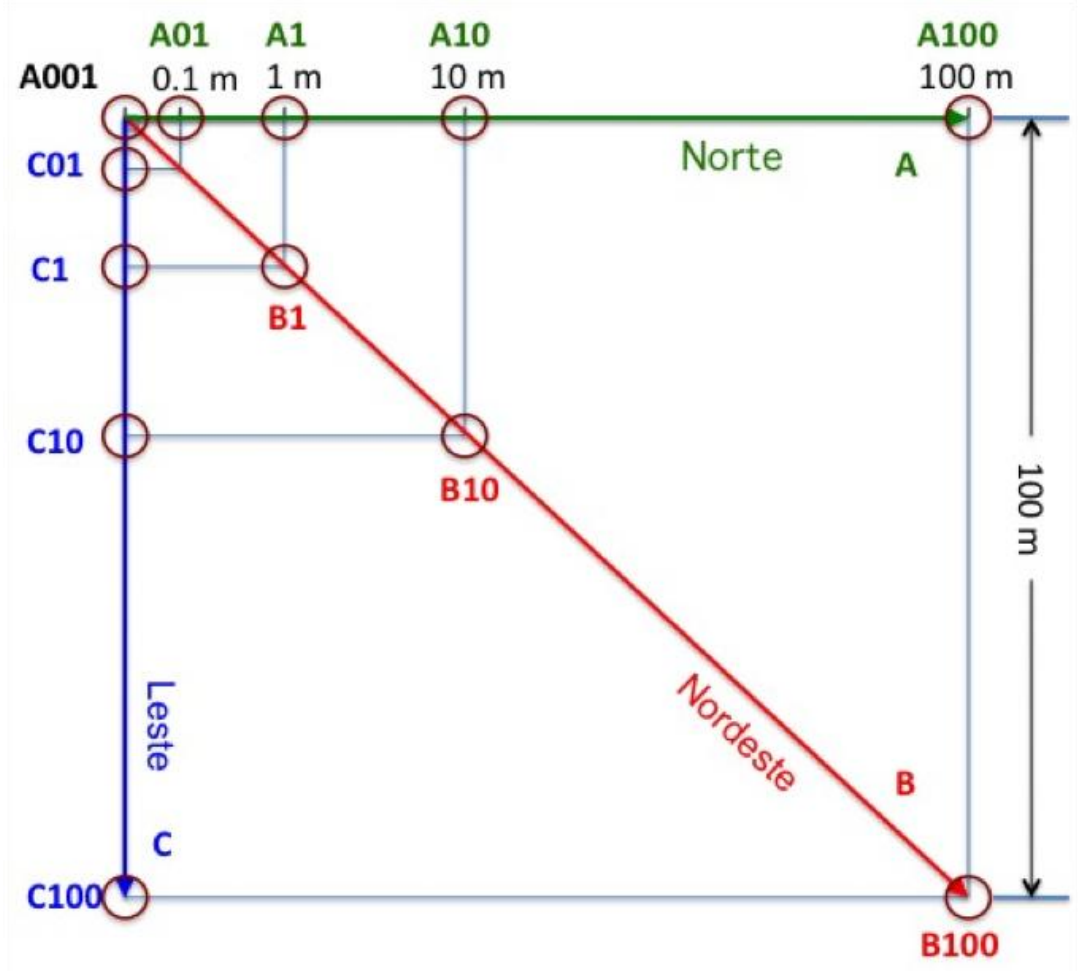

FONTE: A) Google Earth; B) gentilmente cedido por Dr. Klaus Nusslein. 


\subsection{Análise das propriedades físico-químicas do solo}

Para determinação de carbono e nitrogênio totais, as amostras foram secas e peneiradas (malha 100). As análises foram realizadas em auto analisador Leco Truspec CN (St. Joseph, MI, USA), no Laboratório de Biogeoquímica Ambiental do Centro de Energia Nuclear na Agricultura (CENA-USP).

Análises de macro e micro nutrientes e parâmetros de fertilidade do solo foram realizadas no Laboratório de Fertilidade e Classificação de Solo, Departamento de Ciências do Solo da Escola Superior de Agricultura Luiz de Queiroz (ESALQ-USP) de acordo com as técnicas descritas por Van Raij et al. (2001): Fósforo (P): Resina de troca de íons; Boro (B): Colorimetria; Enxofre (S): Turbidimetria; Cálcio $(\mathrm{Ca})$, Magnésio $(\mathrm{Mg})$, Potássio $(\mathrm{K})$, Cobre $(\mathrm{Cu})$, Zinco $(\mathrm{Zn})$, Manganês (Mn), Ferro (Fe): Espectrometria de Absorção Atômica; Alumínio trocável (Al): Titulometria; $\mathrm{pH}$ : $\mathrm{CaCl}_{2}$ 0,01 mol. ${ }^{-1}$; acidez potencial $(\mathrm{H}+\mathrm{Al})$ : $\mathrm{pH}$ SMP; Soma de Bases (SB): $\mathrm{Ca}+\mathrm{Mg}+\mathrm{Na}$; Índice de saturação de alumínio (m): Al*S/SB+Al; Índice de Saturação de Bases $(\mathrm{V})$ : 10*S/T; Capacidade de troca de cátions $(\mathrm{T})$ : $\mathrm{S}+(\mathrm{H}+\mathrm{Al})$; Matéria Orgânica (MO): colorimetria com dicromato de sódio.

As quantidades de areia total, argila e silte foram avaliadas por granulometria, pelo método do densímetro (CAMARGO et al., 1986), no Laboratório de Física do Solo do Departamento de Ciências do Solo (ESALQ-USP).

\subsection{Obtenção do DNA genômico das amostras de solo}

\subsubsection{Extração e purificação do DNA}

A extração do DNA total foi realizada a partir de $250 \mathrm{mg}$ de solo, empregando o kit "PowerLyzer PowerSoil" (Mo Bio Laboratories Inc., Carlsbad, CA, USA), de acordo com as instruções do fabricante e com as seguintes otimizações para as amostras da Amazônia: 1) antes de realizar a etapa de lise, o tubos com "beads", solução de "beads" e solo foram aquecidos por 5 minutos a $60^{\circ} \mathrm{C}$; 2) a etapa de lise das células foi de apenas 8 minutos, para reduzir a fragmentação do DNA; 3) na etapa final, o DNA foi eluído em $50 \mu \mathrm{L}$ de água grau biologia molecular.

Cinco reações de extração foram realizadas para cada amostra, combinadas e concentradas, utilizando o kit "Genomic DNA Clean and Concentrator" (Zymo 
Research Corporation, Irvine, CA, USA), seguindo as instruções do fabricante. O DNA foi eluído em $20 \mu \mathrm{L}$ de água grau biologia molecular. Todas as 60 amostras (12 por sítio) foram usadas nas análises subsequentes.

A pureza do DNA foi verificada por espectrofotometria (Thermo Scientific, Wilmington, DE, USA), checando as razões 260/280 e 260/230, que avaliam, respectivamente, os teores de proteínas e sais no DNA, além da medida de $320 \mathrm{~nm}$, para verificar a presença de ácidos húmicos remanescentes.

\subsubsection{Quantificação do DNA}

A quantificação do DNA purificado foi realizada empregando-se o kit comercial "Quant-iT PicoGreen" (Molecular Probes/Invitrogen, Carlsbad, CA, USA). O reagente PicoGreen se liga apenas a moléculas de DNA de dupla fita e é considerado um método sensível e preciso (SINGER et al., 1997).

Para a realização da curva padrão, DNA de bacteriófago Lambda (Biolabs) foi diluído em Tris-EDTA (TE; Tris-HCl 10 mM, EDTA 1 mM, pH 7.5), obtendo-se cinco pontos de diluição para a curva. Após adicionar o reagente PicoGreen (1X), as reações em duplicata de $200 \mu \mathrm{L}$ foram incubadas por 3 minutos e a fluorescência quantificada em TBS-380 (Turner Biosystems, Sunnyvale, CA, USA). As concentrações finais das 5 diluições da curva padrão foram: 1, 10, 100, 500 e 1000 $\mathrm{ng} / \mathrm{mL}$. Foi realizada também a medida da absorbância do branco ( $T E$ + reagente) e o valor obtido foi subtraído dos demais valores.

Para a quantificação do DNA das amostras, fez-se diluição de 500 e 1000X em TE e ambas concentrações foram testadas, para conferir a sensibilidade da técnica. Os demais passos foram realizados como descrito para a curva padrão. As concentrações de DNA nas amostras foram determinadas por meio de regressão linear simples. 


\subsection{Técnica de microarranjo de DNA - Geochip}

\subsubsection{Marcação do DNA}

O DNA foi marcado com o corante fluorescente cianina 3 (Cy-3), pelo método descrito por Wu et al. (2006), como apresentado a seguir: o DNA genômico $(1,5 \mu \mathrm{g})$ foi desnaturado a $99,9{ }^{\circ} \mathrm{C}$ por 5 minutos, na presença de $15 \mu \mathrm{g}$ de iniciadores randômicos (Invitrogen, Grand Island, NY, USA), e imediatamente resfriado e mantido em gelo. Em seguida, foi adicionada uma solução contendo desoxiribonucleotídios (dAGC-TP 5 mM, dTTP 2,5 mM), fragmento de "Klenow" $40 \mathrm{U}$ (Invitrogen, Grand Island, NY, USA) e corante Cy-3 dUTP 25 nM. A solução teve seu volume final ajustado para $50 \mu \mathrm{L}$ com água grau biologia molecular e em seguida foi incubada por 6 horas a $37^{\circ} \mathrm{C}$, seguido por 3 minutos a $95^{\circ} \mathrm{C}$. O DNA marcado foi purificado com o kit QIAquick (Qiagen, Valencia, CA, USA), de acordo com as instruções do fabricantes, e a incorporação do corante foi checada em nanodrop. Após confirmar a incorporação de aproximadamente 100 pmol de Cy-3, o DNA foi seco em "Speed Vac" (ThermoSavant, Milford, MA) a $45{ }^{\circ} \mathrm{C}$ por 45 minutos e armazenado a $-80^{\circ} \mathrm{C}$ ao abrigo da luz até o uso.

\subsubsection{Pré-hibridização e hibridização}

O DNA marcado foi reidratado com $7,32 \mu \mathrm{L}$ de solução de hibridização contendo: formamida 50\% (J.T. Baker, Philipsburg, NJ, USA); tampão SSC $5 \mathrm{X}$ (Ambion, Austin, TX, USA); SDS $0.1 \% ; 2,68 \mu \mathrm{L}$ de controles de rastreamento "tracking-control" (oligonucleotídeos de 48 pares de base, marcados com Cy3, que hibridizam com sondas controles na lamina do Geochip e rastream possíveis contaminações entre amostras; Roche NimbleGen, Madison, WI, USA); $3 \mu \mathrm{L}$ de padrão universal (oligonucleotídeos, marcados com Cy5, que se ligam a sondas específicas distribuídas uniformemente por toda a lâmina, utilizadas para normalizar a intensidade de sinal dos "spots" positivos das amostras; desenhado no "Institute for environmental Genomics, University of Oklahoma"); e oligonucleotídeos de alinhamento da imagem para Cy3 $(0,17 \mu \mathrm{L})$ e Cy5 $(0,28 \mu \mathrm{L})$ (Roche NimbleGen, Madison, WI, USA). Após agitar em vortex, o DNA em solução foi aquecido a $95^{\circ} \mathrm{C}$ por 5 minutos e mantido a $50^{\circ} \mathrm{C}$ até a aplicação na lâmina de microarranjo (Roche 
NimbleGen, Madison, WI, USA), a qual foi pré-aquecida a $42{ }^{\circ} \mathrm{C}$. Para a hibridização, empregou-se a versão 4.0 do Geochip (Figura 6; Tabela 1). A hibridização foi realizada a $42{ }^{\circ} \mathrm{C}$, por 16 horas, na estação de hibridização Maui (BioMicro Systems, Madison, WI, USA).

Figura 6 - Lâmina do Geochip 4.0. A) Detalhe da lâmina com o sistema de canais que permitem a circulação das amostras durante a hibridização. B) Aplicação do DNA marcado na lâmina.

A)

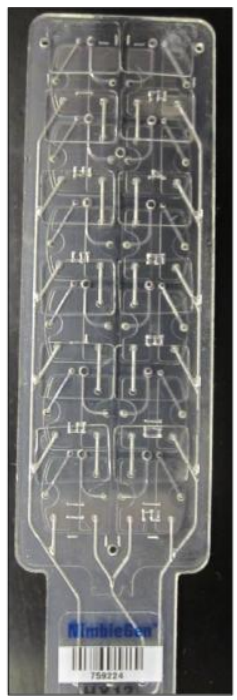

B)

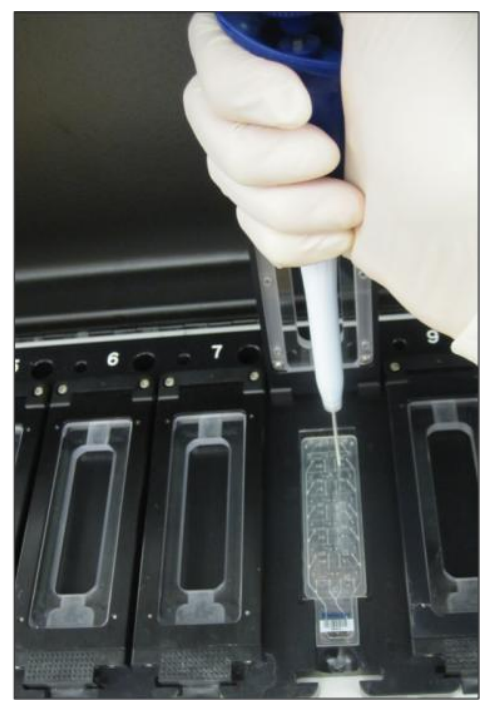

FONTE: arquivo pessoal.

\subsubsection{Lavagem das lâminas}

Após a hibridização, as lâminas foram lavadas com o kit "NimbleGen Wash Buffer" (Roche NimbleGen, Madison, WI, USA). Soluções de $30 \mathrm{~mL}$ dos tampões de lavagem foram previamente preparadas e em seguida adicionado Dithiothreitol 0.1 HM (DTT; NimbleGen, Madison, WI, USA). As lâminas foram incubadas sequencialmente com os tampões I, II e III, por 2 minutos, 1 minuto e 15 segundos, respectivamente, sob agitação constante. Finalmente, as lâminas foram secas em centrífuga para lâminas. 


\subsubsection{Escaneamento e processamento das imagens}

A captura da imagem de hibridização das lâminas foi realizada no scanner "NimbleGen MS200" (Roche, Madison, WI, USA). O programa "NimbleScan 2.5" foi usado para alinhamento das imagens (Figura 7A), obtidas na leitura de Cy-3 (amostras), e Cy-5 (padrão universal), definindo a localização e a intensidade de cada sonda ("spot"). Em seguida, os dados brutos foram submetidos para o programa de análise de dados de microarranjos disponível na página do "Institute for Environmental Genomics" (http://ieg.ou.edu/microarray/). Para tratamento dos dados foram empregados os seguintes passos: 1 . sondas com intensidade de sinal inferior a 1000 e com SNR ("signal noise ratio" - razão sinal: ruído) inferior a 2 foram eliminados, por serem considerados "spots" de baixa qualidade (SNR foi calculado como a intensidade de sinal do "spot" menos o "background", dividido pelo desvio padrão do "background") (Figura 7B); 2. o sinal de cada "spot" foi normalizado, dividindo seu valor pela média dos "spots" do padrão universal, e em seguida dividindo pela média de todas as sondas da amostra (HE et al., 2010a).

A intensidade de sinal normalizada de cada "spot" positivo foi considerada como a abundância de cada gene detectado. A comparação das abundâncias de genes entre as amostras foi possível devido à realização das seguintes etapas durante o experimento: 1) a mesma quantidade de DNA foi utilizada para todas as amostras; 2) a quantidade de corante incorporado foi equivalente para todas as amostras; 3) foi utilizada a mesma quantidade do padrão universal, o qual se liga a sondas específicas no microarranjo; 4) as etapas de normalização consideraram tanto o sinal do padrão universal, quanto a média obtida na amostra. 
Figura 7 - Imagem de hibridização do Geochip 4.0 após alinhamento. A) Imagem completa gerada pela hibridização do DNA de uma amostra, marcado com cy-3, com as sondas do Geochip. B) Ampliação da imagem, destacando um "spot" (S) referente a uma sonda de gene, com hibridização positiva, e seus respectivos "backgrounds" (B), que são empregados para no cálculo do SNR.

A)

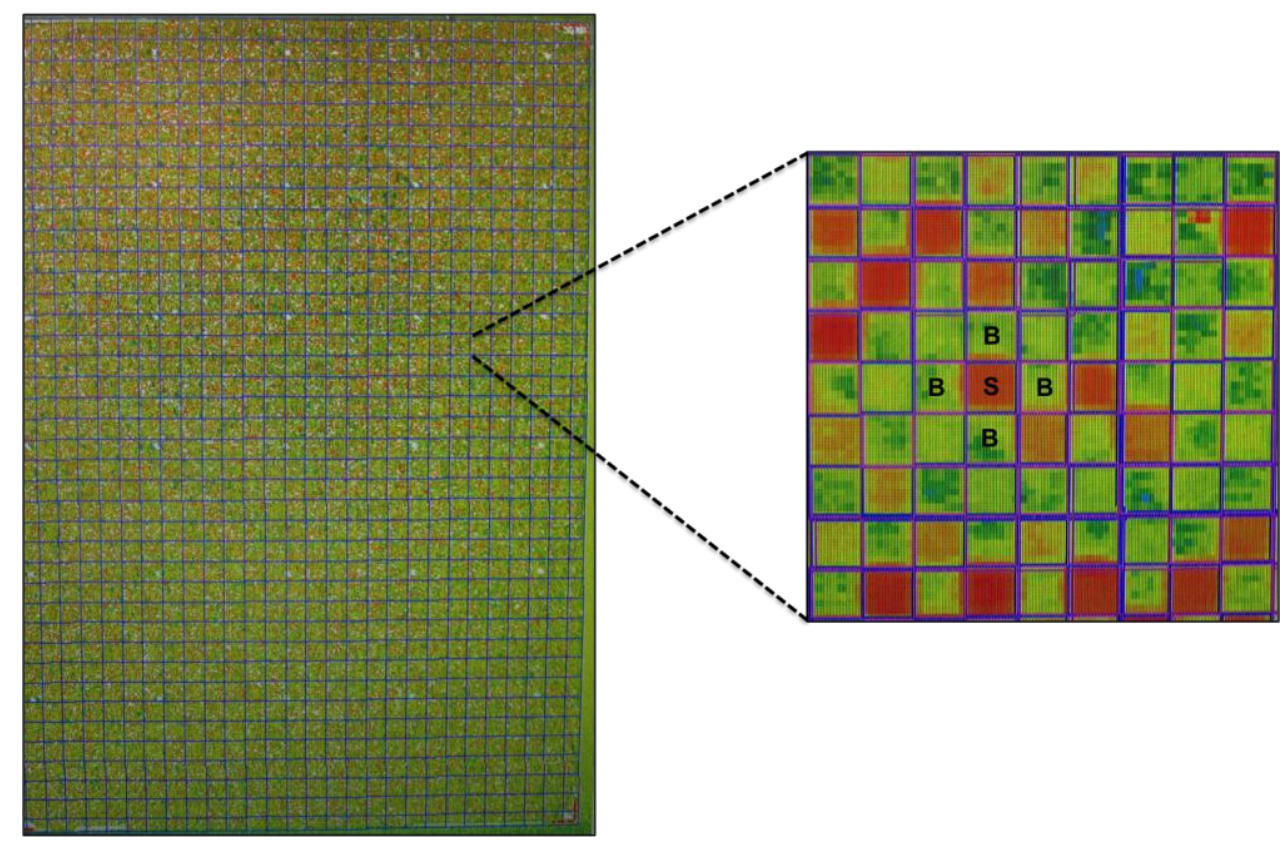

FONTE: arquivo pessoal.

\subsection{Análises estatísticas}

Todas as análises estatísticas foram realizadas na plataforma $R 2.12 .1$ ( $R$ DEVELOPMENT CORE TEAM, 2010) com os pacotes Stats (R DEVELOPMENT CORE TEAM, 2010), Vegan (OKSANEN et al., 2011) e Indicspecies (DE CACERES; LEGENDRE, 2009; DE CACERES; LEGENDRE; MORETTI, 2010).

Anova "one-way", com posterior teste de Tukey, foram empregados para verificar diferenças na riqueza e diversidade de genes entre os sítios de amostragem.

Os dados foram ordenados por NMDS ("nonmetric multidimensional scaling"), usando o índice de Bray-Curtis. NMDS emprega níveis de dissimilaridades entre as amostras para ordena-las no gráfico, de forma que as comunidades funcionais mais similares são plotadas mais próximas. Este método de ordenação foi escolhido, pois 
não pressupõe relação linear entre as variáveis, e é considerado um método robusto para avaliar dados ecológicos de comunidades (CLARKE, 1993).

Análise de similaridade (ANOSIM) (CLARKE, 1993) foi usada para checar as diferenças nos perfis das comunidades. Foram empregadas matrizes de dissimilaridade de Bray-Curtis para calcular a estatística $R$, que compreende valores de 0 a 1 . Quanto maior for 0 valor $R$, maior a diferença entre as comunidades. A significância foi testada por permutação, recalculando o valor de $R 999$ vezes. A hipótese nula do teste era de similaridade entre comunidades. Comparações pareadas foram feitas e os valores de $p$ foram ajustados devido aos múltiplos testes realizados, aplicando-se a correção de Bonferroni. Para as análises de NMDS e ANOSIM as sondas de genes funcionais foram previamente agrupadas por famílias de genes e os valores de intensidades de sinal somados e transformados pela função $\log 2(x+1)$, para reduzir o efeito dos dominantes.

Foi realizada a análise de agrupamento ("clustering") para verificar como as amostras se agrupam, considerando a abundância de genes de cada processo funcional. Para isso, as sondas foram primeiramente agrupadas por processo funcional, somando as intensidades dos sinais, para obter a abundância total de genes de cada processo. Com os valores de abundância, foi construído um "heatmap", utilizando a função heatmap disponível no pacote "stats" do programa $\mathrm{R}$ 2.12.1, onde a intensidade da cor é proporcional à abundância de genes. Os valores foram normalizados para cada processo funcional, com média zero e desvio padrão igual a um. Considerando os perfis de intensidades de cores apresentados por cada amostra, foi realizada a análise de agrupamento hierárquico pelo método de "complete linkage", baseado na distância euclidiana entre as amostras.

As variáveis físico-químicas foram combinadas em uma matriz e testadas quanto à correlação com os eixos do NMDS, empregando a função envfit do pacote Vegan (OKSANEN et al., 2011). Variáveis com correlação significativa $(p<0.05)$ foram mostradas como vetor no gráfico de ordenação, indicando a força e a direção da correlação. Nesta análise foram utilizadas apenas 9 amostras por sítio de amostragem, pois os fatores ambientais não foram quantificados para as demais amostras. Para aproximar os valores de uma distribuição normal, os dos dados ambientais foram transformados por função logarítmica, exceto areia total, pH e V.

O teste de Mantel (LEGENDRE; LEGENDRE, 1998) permitiu avaliar a correlação entre distância espacial e distância ecológica das comunidades dentro de 
cada sítio. Para este propósito, primeiramente foi construída uma matriz para cada sítio de amostragem, com os valores de dissimilaridade (Bray-Curtis) entre os pontos de coleta. Em seguida, fez-se uma matriz de distância espacial, com as distâncias entre todos os pontos do quadrante de $100 \mathrm{~m}^{2}$ da Figura 5B. Finalmente, aplicando a função mantel do pacote Vegan (OKSANEN et al., 2011) foi realizado o teste de correlação entre a matrizes de dissimilaridade e espacial para cada sítio. A significância da correlação foi verificada por um teste de permutação, o qual trocou randomicamente as posições das amostras 999 vezes, refazendo o teste de correlação para cada rearranjo. A um nível de significância de 5\%, foi verificado se a configuração observada poderia ser obtida ao acaso.

A função multipatt do pacote indicspecies (DE CACERES; LEGENDRE, 2009; DE CACERES; LEGENDRE; MORETTI, 2010) foi usada para avaliar se famílias de genes funcionais possuem associação com algum um sítio ou combinação de sítios de amostragem. Foi empregado o índice de correlação $\left(r_{p b}\right)$, que é o coeficiente de Pearson calculado entre uma variável quantitativa (abundância de genes) e uma variável binária (presença e ausência no sítio de amostragem). A correlação de cada família de genes com cada sítio ou combinação de sítios de amostragem foi calculada da seguinte forma:

$$
r_{p b}=\frac{\left(N \times a_{p}-a \times N_{p}\right)}{N \times l^{2}-a^{2} \times N \times N_{p}-N_{p}^{2}}
$$

onde $\mathrm{N}$ é o número total de amostras; $\mathrm{Np}$, o número de amostras no sítio (ou combinação de sítios) avaliado; ap, soma dos valores de abundância da família de genes nas amostras do sítio avaliado; a, soma dos valores de abundância da família de genes em todas as amostras; I, normalização do vetor de abundância. Em seguida, um teste de permutação, conduzido para cada família, permitiu verificar se esta é significativamente associada ao sítio (ou combinação de sítios) com o qual apresentou o maior índice de correlação, sob a hipótese nula de não associação. $O$ método de controle de falsa taxa de descoberta (BENJAMINI; HOCHERG, 1995) foi empregado para corrigir os valores de $p$, devido aos múltiplos testes realizados. 


\section{RESULTADOS}

\subsection{Obtenção de DNA genômico do solo}

Um dos principais pré-requisitos para a realização da técnica de Geochip é a obtenção de DNA de qualidade, isto é, DNA de alto peso molecular, com baixa concentração sais e proteínas, e livre de ácidos húmicos. O uso do kit de extração "PowerLyzer PowerSoil", bem como emprego das otimizações para o solo da Amazônia, o qual é rico em ácidos húmicos, possibilitou a obtenção de DNA dentro dos padrões requisitados (Figura 8 e Tabela 2). Foram necessárias 5 reações de extração de cada amostra para formar um "pool" e então concentrar o material, obtendo uma grande quantidade de DNA (entre 1 e $2 \mu \mathrm{g}$ ) em um volume reduzido $(20 \mu \mathrm{L})$.

Figura 8 - Gel de agarose (1\%) de DNA genômico total extraído de 3 amostras de solo da Amazônia. M: marcador molecular $1 \mathrm{~Kb}$ Pluss Ladder (Fermentas, Burlington, ON, CA); a: floresta primária (amostra A1); b: pastagem de 6 anos (amostra A1); C: floresta secundária (amostra A1).

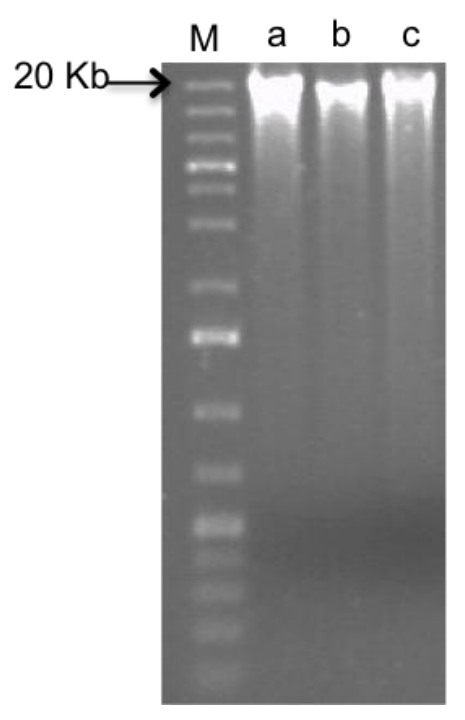

A Tabela 2 mostra as quantidades de DNA após combinação e concentração, e os valores das razões 260/280 e 260/230, relativos às quantidades de proteínas e sais, respectivamente, das 60 amostras estudadas. Os valores de absorbância a 320 $\mathrm{nm}$ (dados não mostrados) foram inferiores a 0,1 para todas as amostras, indicando uma baixa quantidade de ácidos húmicos (NING et al., 2009). 
Tabela 2 - DNA extraído de amostras de solo da Amazônia (continua)

\begin{tabular}{|c|c|c|c|}
\hline Amostra & Concentração de DNA (ng/ $\mu \mathrm{L})^{a}$ & $260 / 280^{b}$ & $260 / 230^{c}$ \\
\hline F-A001 & 148,5 & 1,91 & 2,17 \\
\hline F-A01 & 82,0 & 1,90 & 2,11 \\
\hline F-A1 & 80,1 & 1,91 & 2,03 \\
\hline F-A10 & 167,1 & 1,92 & 2,18 \\
\hline F-A100 & 111,2 & 1,93 & 2,17 \\
\hline F-B1 & 84,5 & 1,90 & 2,14 \\
\hline F-B10 & 116,4 & 1,92 & 2,00 \\
\hline F-B100 & 171,2 & 1,92 & 2,20 \\
\hline $\mathrm{F}-\mathrm{C} 01$ & 179,8 & 1,92 & 2,13 \\
\hline $\mathrm{F}-\mathrm{C} 1$ & 198,9 & 1,90 & 2,12 \\
\hline $\mathrm{F}-\mathrm{C} 10$ & 164,8 & 1,93 & 2,17 \\
\hline $\mathrm{F}-\mathrm{C} 100$ & 142,7 & 1,92 & 2,13 \\
\hline S-A001 & 125,9 & 1,91 & 2,21 \\
\hline S-A01 & 144,6 & 1,91 & 2,07 \\
\hline S-A1 & 124,9 & 1,93 & 2,20 \\
\hline S-A10 & 123,0 & 1,91 & 2,16 \\
\hline S-A100 & 132,2 & 1,91 & 2,19 \\
\hline S-B1 & 121,6 & 1,91 & 2,09 \\
\hline S-B10 & 122,2 & 1,91 & 2,21 \\
\hline S-B100 & 116,0 & 1,89 & 2,08 \\
\hline S-C01 & 153,1 & 1,91 & 2,10 \\
\hline S-C1 & 120,6 & 1,91 & 2,17 \\
\hline S-C10 & 122,6 & 1,90 & 2,01 \\
\hline S-C100 & 99,9 & 1,93 & 2,15 \\
\hline P6-A001 & 105,5 & 1,91 & 2,13 \\
\hline P6-A01 & 132,2 & 1,92 & 2,14 \\
\hline P6-A1 & 114,3 & 1,92 & 2,08 \\
\hline P6-A10 & 97,6 & 1,92 & 1,97 \\
\hline P6-A100 & 217,7 & 1,89 & 2,08 \\
\hline P6-B1 & 180,5 & 1,91 & 1,77 \\
\hline P6-B10 & 151,6 & 1,91 & 2,00 \\
\hline P6-B100 & 181,7 & 1,90 & 2,12 \\
\hline P6-C01 & 98,8 & 1,91 & 2,07 \\
\hline $\mathrm{P} 6-\mathrm{C} 1$ & 137,3 & 1,91 & 2,08 \\
\hline P6-C10 & 100,7 & 1,90 & 1,84 \\
\hline P6-C100 & 142,2 & 1,94 & 2,20 \\
\hline
\end{tabular}


Tabela 2 - DNA extraído de amostras de solo da Amazônia (conclusão)

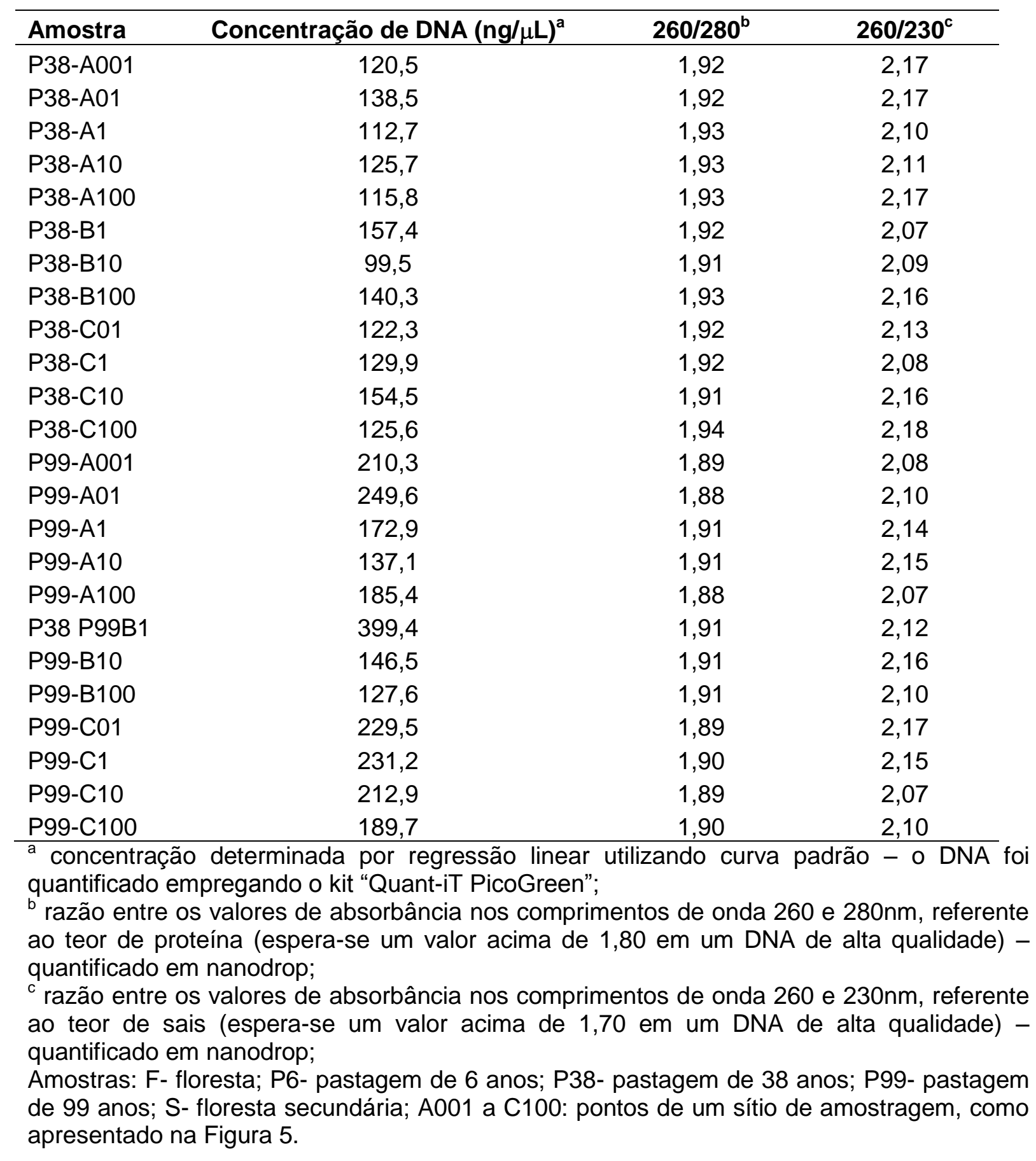




\subsection{Diversidade de genes funcionais}

Para evitar confusão de termos, neste estudo foi adotada a seguinte nomenclatura: Gene Funcional será usado para cada uma das sequências de genes presentes na lâmina do Geochip; Família de Genes se refere a grupos de genes homólogos, codificam enzimas da mesma família, como por exemplo pmoA e amoA, independente do microrganismo de origem; Processo funcional indicará o conjunto de famílias de genes que realizam o mesmo processo, como oxidação de metano e nitrificação; Grupo de processos funcionais se refere a agrupamentos dos mesmos, como ciclo do carbono, nitrogênio, etc.

Após a aplicação do "cut-off" (SNR>2) foi verificada a riqueza de genes funcionais, que consiste no número de sondas de genes com hibridização positiva para cada sítio de amostragem. De 83.992 sondas de genes presentes na lâmina do Geochip, 66.388 foram detectados em pelo menos um sítio de amostragem. A Tabela 3 mostra o número de genes encontrados para cada grupo de processo funcional.

Tabela 3 - Número de genes dos diferentes grupos de processos funcionais detectados em amostras de solo da Amazônia

\begin{tabular}{lccc}
\hline $\begin{array}{l}\text { Grupo de processos } \\
\text { funcionais }\end{array}$ & $\begin{array}{c}\mathbf{N}^{\circ} \text { genes alvo } \\
\text { no Geochip }\end{array}$ & $\begin{array}{c}\mathbf{N}^{\circ} \text { genes } \\
\text { detectados }\end{array}$ & $\begin{array}{c}\text { \% genes } \\
\text { detectados }\end{array}$ \\
\hline Ciclo do Carbono & 11302 & 8903 & 78,8 \\
Ciclo do Enxofre & 3254 & 2624 & 80,6 \\
Ciclo do Fósforo & 1378 & 1123 & 81,5 \\
Ciclo do Nitrogênio & 7552 & 6019 & 79,7 \\
Degradação de compostos orgânicos & 17919 & 14013 & 78,2 \\
Estresse & 21574 & 17121 & 79,4 \\
Genes de bacteriófagos & 1100 & 791 & 71,9 \\
Marcador filogenético & 2390 & 1878 & 78,6 \\
Processos energéticos & 862 & 748 & 86,8 \\
Resistência a antibióticos & 3349 & 2583 & 77,1 \\
Resistência a metais & 9478 & 7591 & 80,1 \\
Virulência & 3732 & 2907 & 77,9 \\
Outros & 102 & 78 & 76,5 \\
Total & 83992 & 66388 & 79,0 \\
\hline
\end{tabular}


A riqueza de genes funcionais encontrada nos cinco sítios estudados está apresentada na Figura 9A (os valores apresentados correspondem à média \pm desvio padrão de 12 amostras). Foram detectados entre 35 e 50 mil genes em cada sítio. A diferença no número de genes entre sítios foi significativa (ANOVA F: 31,0; $p<0,001)$, sendo que as florestas primária e secundária, e pastagem P99 tiveram um número significativamente maior que as demais pastagens $(p<0.05)$. Foi também observada diferença entre P6 e P38.

Com relação às famílias de genes, o número médio não variou muito entre os sítios de amostragem (397 \pm 3 a $406 \pm 1$ ), porém, o teste de ANOVA apontou diferença significativa ( $\mathrm{F}: 18,2 ; p<0,001)$, e a pastagem $\mathrm{P} 6$ teve número menor $(p<0,05)$, comparando com os demais sítios (Figura 9B). 
Figura 9 - Riqueza de genes funcionais em solos da Amazônia submetidos a diferentes formas de uso. As barras representam média \pm desvio padrão de 12 amostras por sítio. A) número de sondas de genes com hibridizações positivas. B) número de famílias de genes detectadas. ${ }^{\text {a,b,c }}$ sítios que não compartilham a mesma letra são considerados significativamente diferentes entre si (ANOVA e teste de Tukey, $p<0,05)$. F- floresta; S- floresta secundária; P6- pastagem de 6 anos; P38- pastagem de 38 anos; P99- Pastagem de 99 anos;

\section{A}

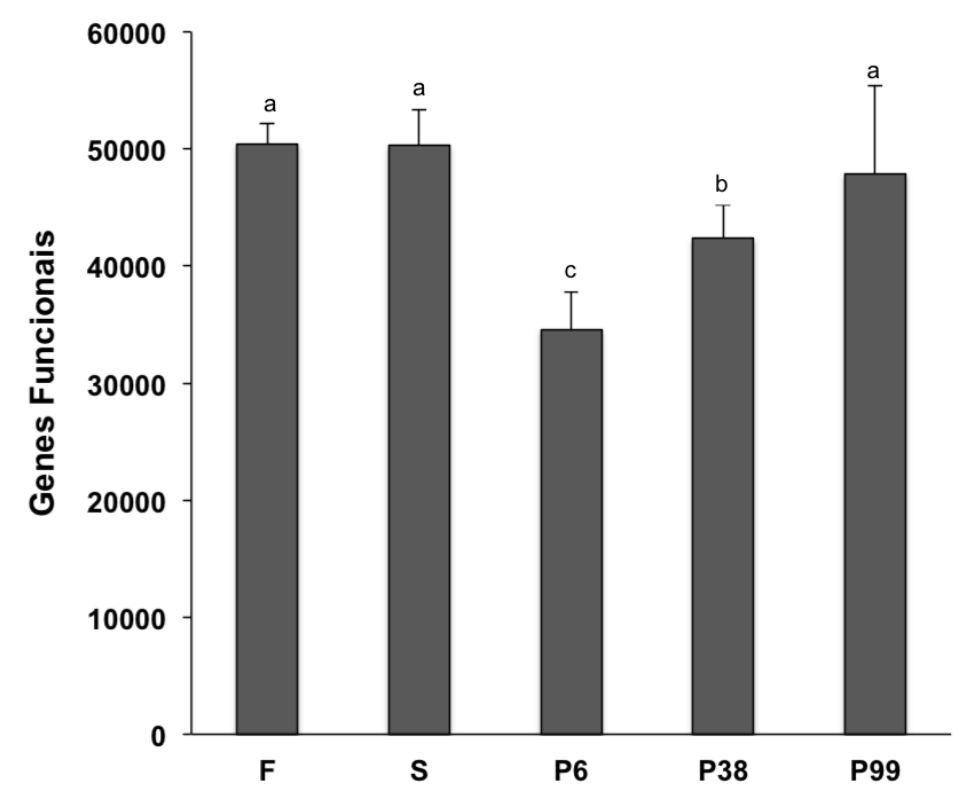

B

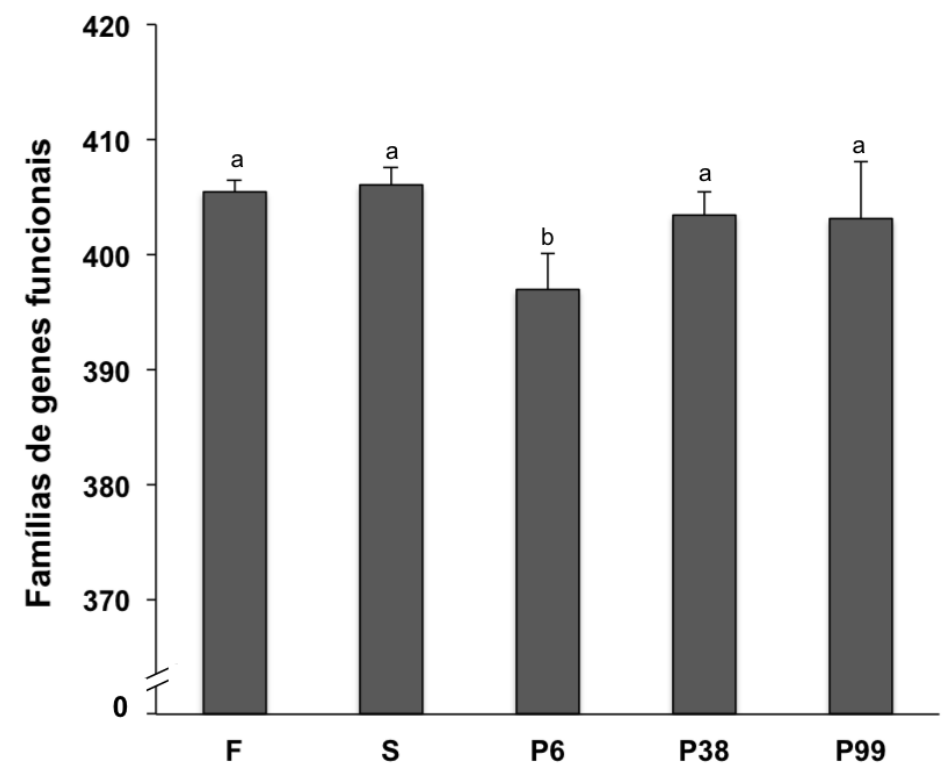


O índice Shannon-Weaver $H^{\prime}$ foi utilizado para acessar a diversidade de genes nas amostras (Tabela 4). Os valores obtidos para todos os sítios foram muito semelhantes, entretanto o teste de ANOVA demonstrou que houve efeito do tratamento ( $\mathrm{F}: 21,8 ; p<0,001)$. As florestas e a pastagem P99 tiveram índices de diversidade mais elevados e semelhantes entre si. Também não foi encontrada diferença significativa entre P38 e P99. P6 foi significativamente menos diversa que todos os outros sítios.

Tabela 4 - Diversidade de genes funcionais acessada pelo índice de Shannon-Weaver H'

\begin{tabular}{ccccc}
\hline Floresta & $\begin{array}{c}\text { Pastagem } \\
\mathbf{6} \text { anos }\end{array}$ & $\begin{array}{c}\text { Pastagem } \\
\mathbf{3 8} \text { anos }\end{array}$ & $\begin{array}{c}\text { Pastagem } \\
\mathbf{9 9} \text { anos }\end{array}$ & $\begin{array}{c}\text { Floresta } \\
\text { Secundária }\end{array}$ \\
\hline $10,61 \pm 0,04^{\mathrm{a}}$ & $10,31 \pm 0,09^{\mathrm{c}}$ & $10,45 \pm 0,07^{\mathrm{b}}$ & $10,55 \pm 0,16^{\mathrm{ab}}$ & $10,60 \pm 0,04^{\mathrm{a}}$ \\
\hline $\mathrm{a}, \mathrm{b}, \mathrm{c}$ & valores que não compartilham a mesma letra são & considerados & significativamente \\
diferentes entre si (ANOVA e teste de Tukey, $p<0.05)$. & &
\end{tabular}

Ao avaliar os diferentes processos funcionais separadamente, verificou-se que o número de sondas de genes com hibridizações positivas também variou entre os sítios de amostragem, seguindo um padrão semelhante ao visualizado para o número total (Tabela 5). 


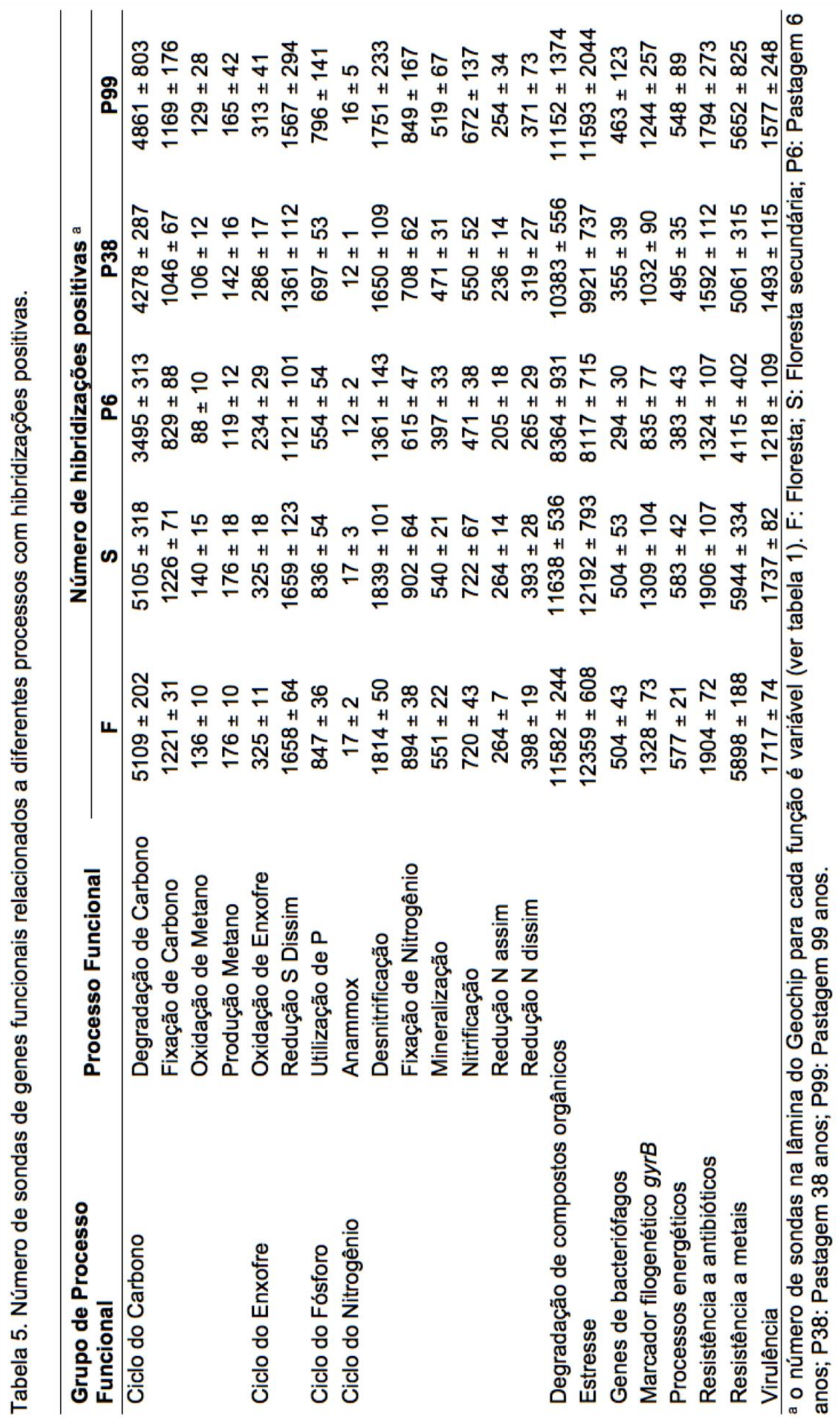




\subsection{Estrutura funcional das comunidades microbianas do solo}

\subsubsection{Ordenação em escala multidimensional não métrica (NMDS)}

A análise de NMDS foi utilizada para verificar como as amostras se agrupam baseado na estrutura funcional das comunidades. Como pode ser observado na Figura 10, as amostras da pastagem P6 se distanciaram das demais amostras e se organizaram de forma dispersa, indicando baixa similaridade entre suas comunidades. Os pontos da pastagem P38 também se separaram dos demais pontos. As amostras das florestas primária e secundária se mostraram similares entre si, estando a maioria dos pontos sobrepostos no gráfico. A pastagem P99, apesar de possuir alguns pontos mais distanciados, não formando um grupo bem definido, teve a maioria das amostras agrupadas com as florestas. $O$ baixo valor de stress $(0,07)$ indica que a ordenação é uma boa representação da estrutura da comunidade.

Figura 10 - Ordenação em escala multidimensional não métrica da estrutura funcional das comunidades microbianas de solos da Amazônia submetidos a diferentes formas de uso. Índice de dissimilaridade: Bray-Curtis. Stress = 0,07.

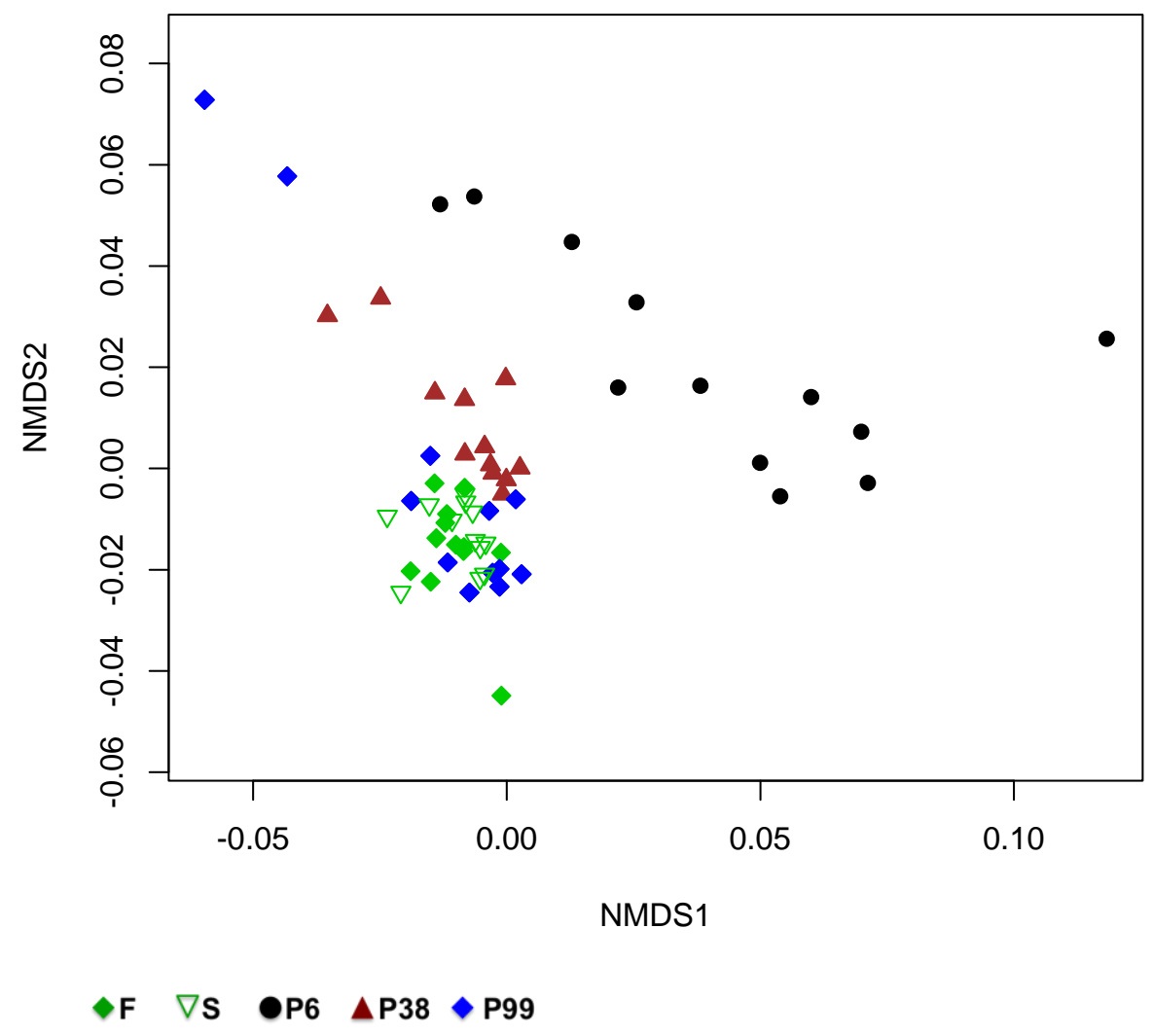




\subsubsection{Análise de similaridade}

Para avaliar o efeito do uso do solo sobre a estrutura das comunidades funcionais foi realizada a análise de similaridade (ANOSIM), que testa se as diferenças entre-sítios são maiores que as diferenças intra-sítios. O teste revelou diferença significativa entre os sítios ( $R: 0,387 ; p=0,001)$. Comparações dois a dois entre os sítios de amostragem estão apresentadas na Tabela 6. Como esperado, os resultados concordaram com o gráfico NMDS (Figura 10). Comparações entre floresta, floresta secundária e pastagem P99 não tiveram resultados significativos, sugerindo similaridade entre as comunidades. Em todas as demais comparações os sítios foram considerados diferentes entre si $(p<0,05)$.

Tabela 6 - Análise de similaridade (ANOSIM). Comparações entre as estruturas funcionais das comunidades microbianas em solos da Amazônia submetidos a diferentes formas de uso ${ }^{\mathrm{a}}$.

\begin{tabular}{|c|c|c|c|c|c|}
\hline & Floresta & $\begin{array}{c}\text { Pastagem } \\
6 \text { anos }\end{array}$ & $\begin{array}{c}\text { Pastagem } \\
38 \text { anos }\end{array}$ & $\begin{array}{c}\text { Pastagem } \\
99 \text { anos }\end{array}$ & $\begin{array}{c}\text { Floresta } \\
\text { Secundária }\end{array}$ \\
\hline Floresta & & 0,888 & 0,457 & 0,104 & 0,014 \\
\hline $\begin{array}{c}\text { Pastagem } \\
6 \text { anos }\end{array}$ & $0,01^{*}$ & & 0,640 & 0,574 & 0,897 \\
\hline $\begin{array}{c}\text { Pastagem } \\
38 \text { anos }\end{array}$ & $0,01^{*}$ & $0,01^{*}$ & & 0,211 & 0,471 \\
\hline $\begin{array}{c}\text { Pastagem } \\
99 \text { anos }\end{array}$ & 0,42 & $0,01^{*}$ & $0,01^{*}$ & & 0,123 \\
\hline $\begin{array}{c}\text { Floresta } \\
\text { Secundária }\end{array}$ & 0,99 & $0,01^{*}$ & $0,01^{*}$ & 0,35 & \\
\hline
\end{tabular}




\subsubsection{Análise de agrupamento}

Avaliou-se como as amostras estudadas se agrupam, considerando a abundância de genes para cada processo funcional. Para este fim, foi construído um dendrograma de distância euclidiana entre as amostras, baseado nos perfis de coloração de um "heatmap" que reflete a abundância de genes de cada processo funcional. Como pode ser visto na parte superior da Figura 11, formou-se um agrupamento composto apenas por amostras das florestas, principalmente da floresta primária. Muitas amostras de $S$ (7) se distribuíram em agrupamentos com as pastagens P38 e P99, que são encontradas principalmente na região central da figura. Por outro lado, apensas poucas (4) amostras de F agruparam com pastagens. Todas as amostras de P6, se concentraram na parte inferior da figura, onde podem ser visualizados também pontos de P38 e P99.

Nesta figura é possível observar que os perfis de intensidade de cor variam de acordo com o processo funcional. 
Figura 11 - "Heatmap" com análise de agrupamento. As colunas são os processos funcionais e as linhas são as amostras. A intensidade da cor azul é proporcional à abundância de genes para cada processo funcional em cada amostra. A barra de cores ao lado esquerdo é referente aos sítios de amostragem (ver legenda de cores). A análise de Cluster foi feita empregando distância euclidiana. Os nomes completos dos processos funcionais estão na Tabela 5.
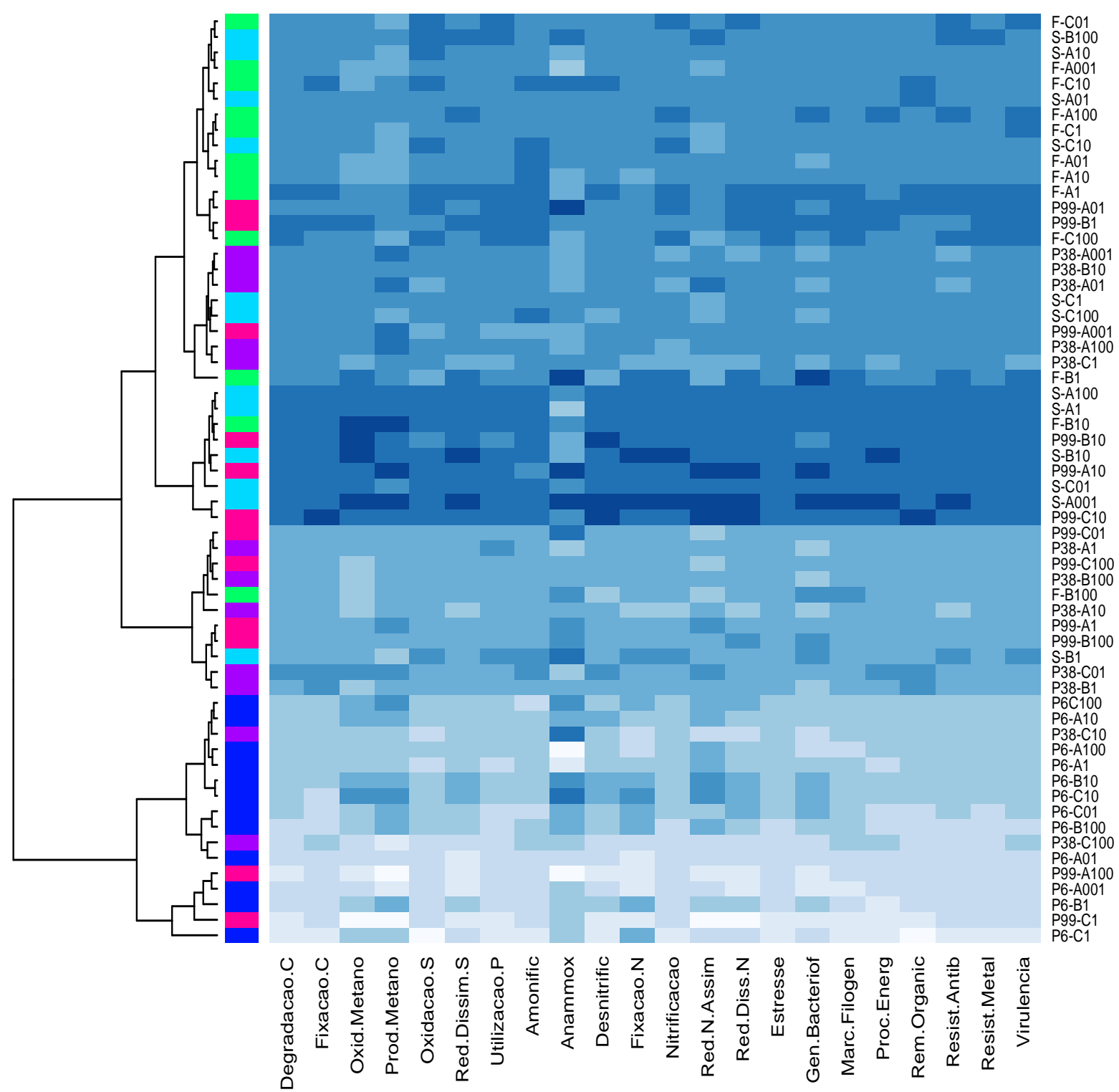


\subsection{Influência de fatores ambientais sobre a estrutura funcional da comunidade}

\subsubsection{Quantificação dos fatores físico-químicos}

A Tabela 7 mostra os valores médios obtidos nas análises físico-químicas para cada sítio de amostragem, bem como os resultados do teste de ANOVA. Não foram realizadas as análises dos pontos A001, A01 e C01 e portanto estão disponíveis os resultados de apenas 9 amostras por sítio. No Anexo A podem ser encontradas as quantificações de todos as amostras separadamente.

Tabela 7 - Quantificações das variáveis físico-químicas das amostras de solo (continua)

\begin{tabular}{|c|c|c|c|c|c|}
\hline \multirow[t]{2}{*}{ Variável } & \multicolumn{5}{|c|}{ Sítio de amostragem } \\
\hline & $\mathbf{F}$ & $\mathbf{S}$ & P6 & P38 & P99 \\
\hline $\mathrm{C}$ & $14,3 \pm 8,8^{b}$ & $20,2 \pm 8,9^{a b}$ & $19,5 \pm 14,4^{\mathrm{ab}}$ & $16,8 \pm 3,4^{\mathrm{ab}}$ & $29,8 \pm 13,5^{\mathrm{a}}$ \\
\hline $\mathrm{N}$ & $1,0 \pm 0,4^{b}$ & $1,5 \pm 0,4^{\mathrm{ab}}$ & $1,2 \pm 0,9^{b}$ & $1,0 \pm 0,2^{b}$ & $2,2 \pm 1,0^{\mathrm{a}}$ \\
\hline $\mathrm{C} / \mathrm{N}$ & $14,8 \pm 4,1^{\mathrm{ab}}$ & $13,3 \pm 2,1^{b}$ & $16,6 \pm 2,0^{\mathrm{a}}$ & $16,6 \pm 1,3^{\mathrm{a}}$ & $13,6 \pm 1,3^{\mathrm{ab}}$ \\
\hline MO & $21,9 \pm 8,1^{b c}$ & $15,0 \pm 3,3^{c}$ & $24,4 \pm 10,7^{b}$ & $27,8 \pm 2,3^{b}$ & $40,6 \pm 6,5^{\mathrm{a}}$ \\
\hline $\mathrm{pH}$ & $4,4 \pm 0,5^{\mathrm{ab}}$ & $4,0 \pm 0,3^{b}$ & $4,7 \pm 0,3^{\mathrm{a}}$ & $4,6 \pm 0,2^{a}$ & $4,7 \pm 0,2^{\mathrm{a}}$ \\
\hline $\mathrm{Al}$ & $2,0 \pm 1,8^{b}$ & $4,2 \pm 2,3^{a}$ & $0,9 \pm 0,8^{b}$ & $1,3 \pm 0,5^{b}$ & $1,0 \pm 0,9^{b}$ \\
\hline $\mathrm{H}+\mathrm{Al}$ & $23,7 \pm 6,3^{b}$ & $30,0 \pm 3,3^{a}$ & $20,7 \pm 2,9^{b}$ & $21,7 \pm 2,9^{b}$ & $34,6 \pm 5,2^{a}$ \\
\hline SB & $24,7 \pm 14,0^{\mathrm{ab}}$ & $8,6 \pm 5,1^{c}$ & $16,9 \pm 9,9^{b c}$ & $15,0 \pm 2,3^{b c}$ & $29,3 \pm 10,2^{a}$ \\
\hline $\mathrm{P}$ & $6,2 \pm 1,5^{\mathrm{ab}}$ & $4,9 \pm 0,9^{a b}$ & $3,1 \pm 0,3^{b}$ & $3,9 \pm 1,1^{b}$ & $12,3 \pm 13,8^{a}$ \\
\hline S & $9,4 \pm 1,3^{b}$ & $15,6 \pm 5,4^{\mathrm{a}}$ & $11,4 \pm 4,8^{\mathrm{ab}}$ & $7,8 \pm 0,7^{b}$ & $10,2 \pm 1,9^{b}$ \\
\hline K & $1,5 \pm 1,7^{\mathrm{a}}$ & $0,9 \pm 0,5^{\mathrm{a}}$ & $1,1 \pm 0,4^{\mathrm{a}}$ & $1,3 \pm 0,4^{a}$ & $1,6 \pm 0,5^{a}$ \\
\hline $\mathrm{Ca}$ & $17,4 \pm 10,6^{a}$ & $5,6 \pm 3,9^{b}$ & $12,1 \pm 8,3^{\mathrm{ab}}$ & $10,8 \pm 2,3^{\mathrm{ab}}$ & $19,4 \pm 7,6^{\mathrm{a}}$ \\
\hline $\mathrm{Mg}$ & $5,8 \pm 3,8^{\mathrm{ab}}$ & $2,1 \pm 1,0^{c}$ & $3,7 \pm 1,6^{b c}$ & $2,9 \pm 0,8^{b c}$ & $8,3 \pm 2,9^{a}$ \\
\hline $\mathrm{T}$ & $48,4 \pm 11,2^{b}$ & $38,6 \pm 5,5^{b}$ & $37,6 \pm 12,1^{b}$ & $36,6 \pm 4,7^{b}$ & $63,9 \pm 8,7^{a}$ \\
\hline V & $48,9 \pm 16,9^{a}$ & $21,4 \pm 10,7^{b}$ & $42,3 \pm 11,3^{a}$ & $40,8 \pm 3,4^{a}$ & $45,2 \pm 10,3^{a}$ \\
\hline $\mathrm{m}$ & $9,6 \pm 8,5^{a}$ & $37,4 \pm 24,0^{a}$ & $7,7 \pm 7,5^{\mathrm{a}}$ & $8,3 \pm 3,5^{a}$ & $4,1 \pm 4,7^{\mathrm{a}}$ \\
\hline B & $0,23 \pm 0,04^{a}$ & $0,20 \pm 0,03^{\mathrm{ab}}$ & $0,15 \pm 0,02^{c}$ & $0,17 \pm 0,02^{b}$ & $0,16 \pm 0,03^{c}$ \\
\hline $\mathrm{Cu}$ & $1,1 \pm 0,4^{b}$ & $0,6 \pm 0,2^{c}$ & $1,3 \pm 0,3^{b}$ & $1,2 \pm 0,3^{b}$ & $2,1 \pm 0,5^{a}$ \\
\hline
\end{tabular}


Tabela 7 - Quantificações das variáveis físico-químicas das amostras de solo (conclusão)

\begin{tabular}{cccccc}
\hline Variável & \multicolumn{4}{c}{ Sítio de amostragem } \\
\cline { 2 - 5 } & $\mathbf{F}$ & $\mathbf{S}$ & $\mathbf{P 6}$ & $\mathbf{P 3 8}$ & $\mathbf{P 9 9}$ \\
\hline Fe & $52 \pm 19^{\mathrm{b}}$ & $38 \pm 4^{\mathrm{b}}$ & $110 \pm 67^{\mathrm{ab}}$ & $89 \pm 18^{\mathrm{b}}$ & $188 \pm 142^{\mathrm{a}}$ \\
Mn & $57,9 \pm 23,7^{\mathrm{b}}$ & $178,6 \pm 59,4^{\mathrm{a}}$ & $22,9 \pm 9,6^{\mathrm{b}}$ & $30,3 \pm 6,0^{\mathrm{b}}$ & $63,7 \pm 30,0^{\mathrm{b}}$ \\
Zn & $0,8 \pm 0,3^{\mathrm{a}}$ & $2,1 \pm 3,6^{\mathrm{a}}$ & $1,5 \pm 0,8^{\mathrm{a}}$ & $1,6 \pm 0,4^{\mathrm{a}}$ & $3,0 \pm 1,9^{\mathrm{a}}$ \\
Silte & $26,4 \pm 9,4^{\mathrm{a}}$ & $30,2 \pm 6,7^{\mathrm{a}}$ & $22,9 \pm 8,9^{\mathrm{a}}$ & $28,2 \pm 7,7^{\mathrm{a}}$ & $31,2 \pm 12,9^{\mathrm{a}}$ \\
Areia & $767 \pm 24^{\mathrm{a}}$ & $761 \pm 44^{\mathrm{a}}$ & $615 \pm 78^{\mathrm{b}}$ & $779 \pm 76^{\mathrm{a}}$ & $564 \pm 132^{\mathrm{b}}$ \\
Argila & $206 \pm 30^{\mathrm{b}}$ & $209 \pm 40^{\mathrm{b}}$ & $362 \pm 80^{\mathrm{a}}$ & $192 \pm 78^{\mathrm{b}}$ & $404 \pm 129^{\mathrm{a}}$ \\
\hline
\end{tabular}

Valores expressos como média \pm desvio padrão de 9 quantificações.

a,b,c valores na mesma linha que não compartilham a mesma letra são considerados significativamente diferentes entre si (ANOVA e teste de Tukey, $p<0.05$ ).

$\mathrm{C}, \mathrm{N}$, silte, areia e argila estão expressos em g. $\mathrm{Kg}^{-1}$; Matéria Orgânica (MO) está expressa em g. $\mathrm{dm}^{-3} ; \mathrm{Al}^{+3}$, acidez potencial $(\mathrm{H}+\mathrm{Al})$, soma de bases $(\mathrm{SB}), \mathrm{K}^{+}, \mathrm{Ca}^{+2}, \mathrm{Mg}^{+3}$ e capacidade de troca de cátions em $\mathrm{pH} 7(\mathrm{~T})$ estão expressos em mmol c. $\mathrm{dm}^{-3}$; P e $\mathrm{S}$ estão expressos em $\mathrm{mg} \cdot \mathrm{dm}^{-3}$; índice de saturação de base (V) e índice de saturação de $\mathrm{Al}(\mathrm{m})$ estão expressos em \%; B, Cu, Fe, Mn, Zn estão expressos em mg.dm ${ }^{-3}$.

F: floresta primária; S: floresta secundária; P6: pastagem 6 anos; P38: pastagem 38 anos; P99: pastagem 99 anos.

5.4.2 Correlações entre os fatores físico-químicos e a estrutura funcional da comunidade

Com o intuito de procurar por possíveis influencias dos fatores ambientais sobre a estrutura funcional da comunidade, variáveis físico-químicas foram testadas quanto à correlação com a ordenação das amostras no NMDS. Na Tabela 8 estão apresentadas as coordenadas dos vetores das variáveis ambientais, e os resultados do teste de correlação dos vetores com os eixos do NMDS, com a significância do teste. 
Tabela 8 - Coordenadas dos vetores das variáveis ambientais e correlação com a ordenação do NMDS ${ }^{\text {a }}$

\begin{tabular}{|c|c|c|c|c|}
\hline Variável & NMDS1 $^{\mathrm{b}}$ & NMDS2 $^{b}$ & $r^{2 c}$ & $p^{d}$ \\
\hline $\mathrm{N}$ & $-0,70876$ & 0,70545 & 0,160 & $0,032^{*}$ \\
\hline$C$ & $-0,58494$ & 0,81107 & 0,147 & $0,035^{\star}$ \\
\hline $\mathrm{C} / \mathrm{N}$ & 0,62784 & 0,77834 & 0,078 & 0,179 \\
\hline MO & $-0,25855$ & 0,96600 & 0,150 & $0,038^{*}$ \\
\hline $\mathrm{pH}$ & 0,40897 & 0,91255 & 0,118 & 0,079 \\
\hline $\mathrm{Al}$ & $-0,29221$ & $-0,95635$ & 0,163 & $0,030^{*}$ \\
\hline $\mathrm{H}+\mathrm{Al}$ & $-0,96873$ & $-0,24811$ & 0,169 & $0,026^{*}$ \\
\hline SB & $-0,55601$ & 0,83117 & 0,024 & 0,599 \\
\hline$P$ & $-0,95986$ & $-0,28049$ & 0,222 & $0,020^{*}$ \\
\hline$S$ & 0,28691 & $-0,95796$ & 0,042 & 0,389 \\
\hline K & $-0,30243$ & 0,95317 & 0,013 & 0,773 \\
\hline $\mathrm{Ca}$ & $-0,49689$ & 0,86781 & 0,025 & 0,584 \\
\hline $\mathrm{Mg}$ & $-0,69745$ & 0,71664 & 0,024 & 0,617 \\
\hline $\mathrm{T}$ & $-0,99988$ & 0,01537 & 0,128 & 0,052 \\
\hline M & $-0,19536$ & $-0,98073$ & 0,082 & 0,190 \\
\hline V & 0,28968 & 0,95712 & 0,017 & 0,715 \\
\hline$B$ & $-0,59908$ & $-0,80069$ & 0,283 & $0,003^{* *}$ \\
\hline $\mathrm{Cu}$ & $-0,10175$ & 0,99481 & 0,074 & 0,221 \\
\hline $\mathrm{Fe}$ & 0,10018 & 0,99497 & 0,111 & 0,102 \\
\hline $\mathrm{Mn}$ & $-0,71859$ & $-0,69543$ & 0,308 & $0,001^{\star \star \star}$ \\
\hline $\mathrm{Zn}$ & $-0,10376$ & 0,99460 & 0,009 & 0,832 \\
\hline Silte & $-0,69195$ & $-0,72195$ & 0,046 & 0,375 \\
\hline Areia & $-0,44013$ & $-0,89793$ & 0,100 & 0,115 \\
\hline Argila & 0,52506 & 0,85106 & 0,115 & 0,083 \\
\hline
\end{tabular}

a resultados obtidos empregando a análise envfit (OKSANEN et al., 2011)

${ }^{\mathrm{b}} \mathrm{NMDS} 1$ e 2: valores das coordenadas dos vetores das variáveis ambientais.

c $r^{2}$ : coeficiente de correlação entre a variável ambiental e a estrutura da comunidade funcional (scores do NMDS);

${ }^{d} p$ : significância estatística do teste de correlação. * $p<0,05 ;{ }^{* *} p<0,01 ;{ }^{* * *} p<0,001$

Os vetores com correlação significativa foram plotados no gráfico de NMDS (Figura 12). Note que neste gráfico há apenas 45 amostras (9 por sítio de amostragem). A retirada de algumas amostras causa uma pequena alteração na disposição dos pontos, porém a estrutura se assemelha àquela encontrada na Figura 10. A comunidade da pastagem P6 não teve correlação positiva com nenhuma variável ambiental. Já as comunidades de Florestas primária e secundária se relacionaram com maiores concentrações de alumínio, boro, manganês e fósforo e com maior acidez potencial, se comparadas às pastagens P6 e P38, e alguns 
pontos da pastagem P99. Maiores quantidades de matéria orgânica, carbono e nitrogênio tiveram maior relação com P38 e algumas amostras de P99.

Figura 12 - NMDS da estrutura funcional das comunidades, determinada por Geochip e correlação com variáveis ambientais. Somente as variáveis com correlação significativa $(p<0,05)$ estão apresentadas na figura. Índice de dissimilaridade: Bray-Curtis. Stress $=0,08$. C: carbono total ; N: nitrogênio total; MO: matéria orgânica; Al: alumínio; H_Al: acidez potencial; B: boro; P: fósforo; Mn: manganês.

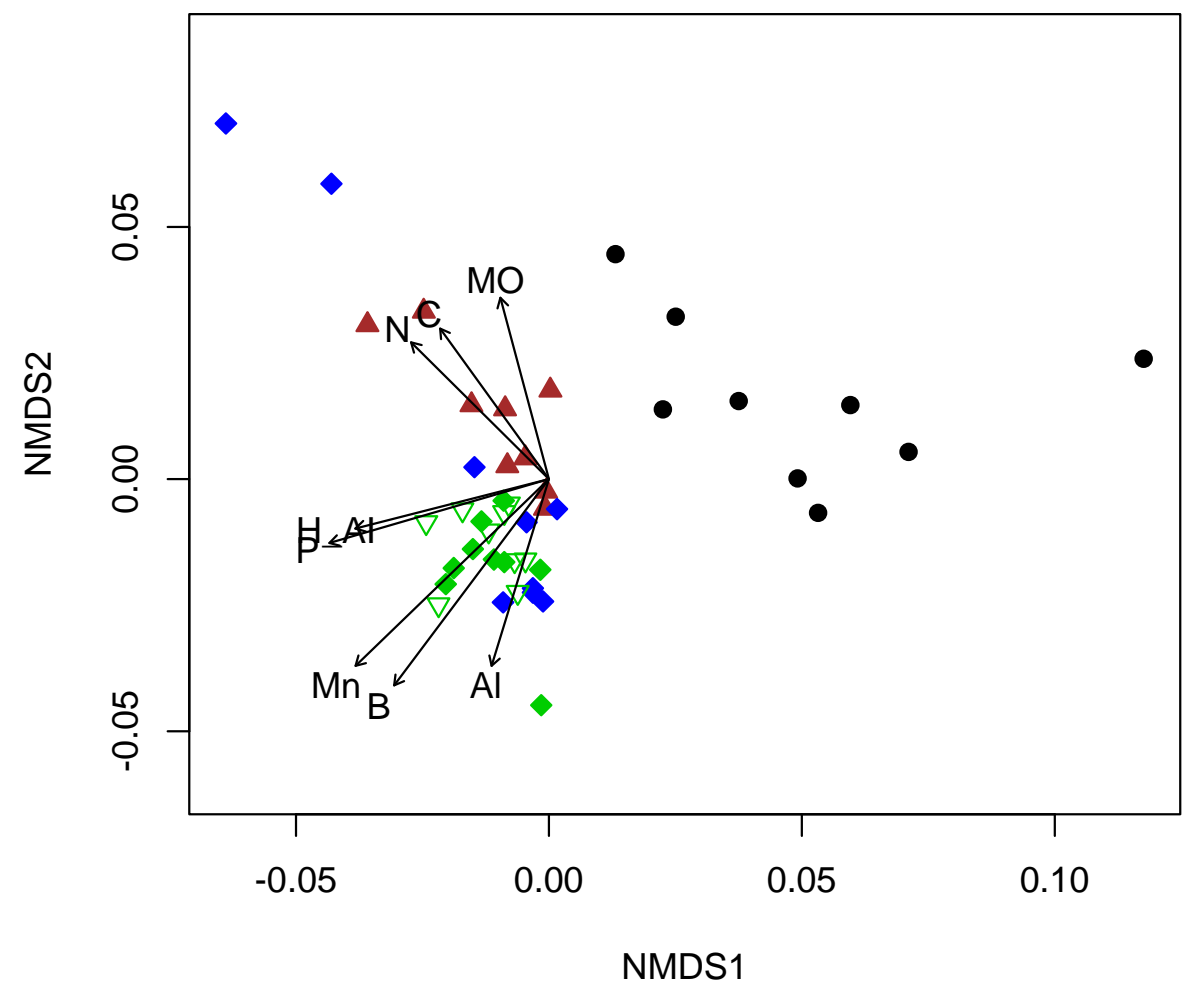

$\diamond \mathrm{F} \quad \nabla \mathrm{S} \quad$ OP6 $\quad \Delta \mathrm{P} 38 \diamond \mathrm{P} 99$

Os oito fatores físico-químicos que tiveram correlação significativa com a estrutura do NMDS estão apresentadas em forma de gráfico de pontos na Figura 13. Estes gráficos possibilitam uma visualização mais clara das variações entre os sítios de amostragem e das diferenças apresentadas pela pastagem P99, quanto aos valores de alguns fatores (Figura $13 \mathrm{~A}-\mathrm{H}$ ). São observados alguns pontos de P99 com valores mais elevados de $\mathrm{C}, \mathrm{N}, \mathrm{MO}, \mathrm{P}$ e $\mathrm{H}+\mathrm{Al}$, em relação às demais pastagens. 
Figura 13. Quantificações de fatores físico-químicos que tiveram correlação significativa com a estrutura funcional das comunidades microbianas em solos da Amazônia. A) Carbono; B) Nitrogênio; C) Matéria Orgânica; D) Fósforo; E) Alumínio; F) Acidez potencial $(\mathrm{H}+\mathrm{Al})$; $\mathrm{G})$ Manganês; $\mathrm{H})$ Boro (continua).

A)

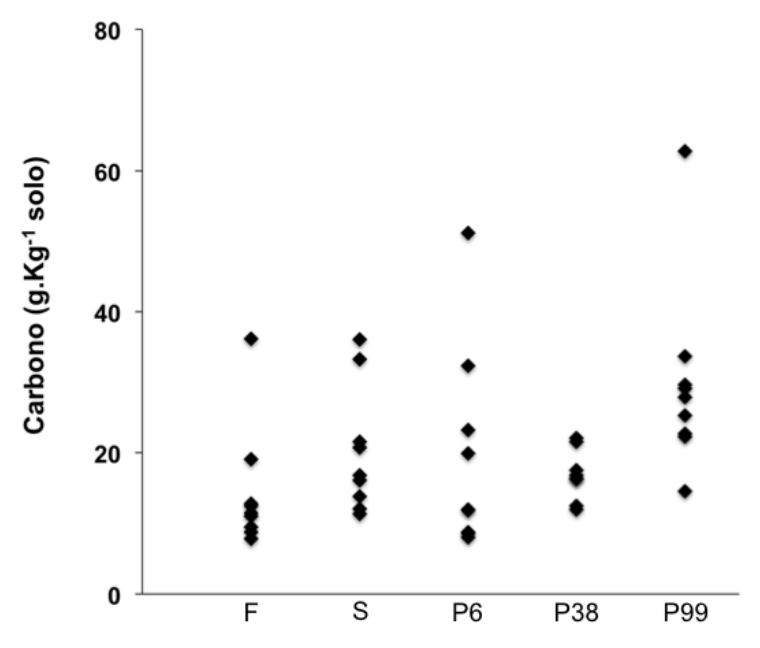

C)

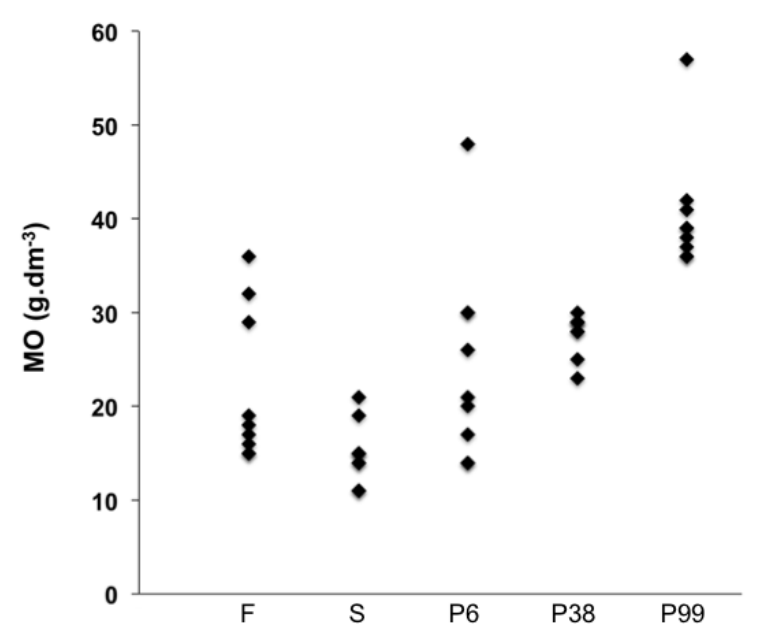

B)

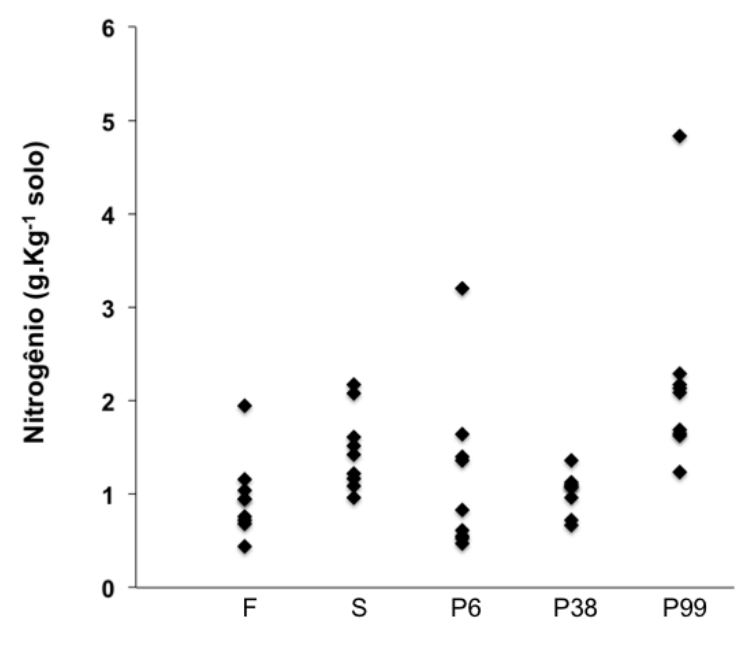

D)

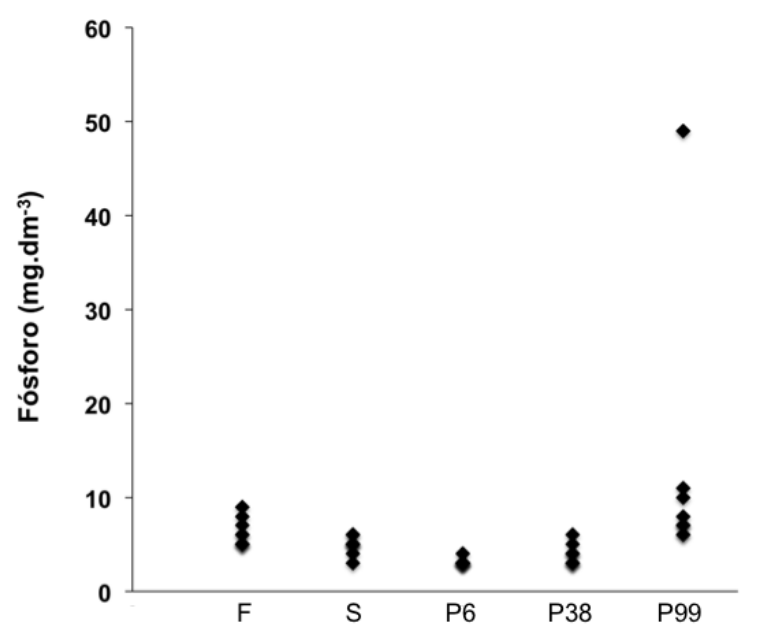


Figura 13. Quantificações de fatores físico-químicos que tiveram correlação significativa com a estrutura funcional das comunidades microbianas em solos da Amazônia. A) Carbono; B) Nitrogênio; C) Matéria Orgânica; D) Fósforo; E) Alumínio; F) Acidez potencial $(\mathrm{H}+\mathrm{Al})$; $\mathrm{G})$ Manganês; H) Boro (continuação).

E)

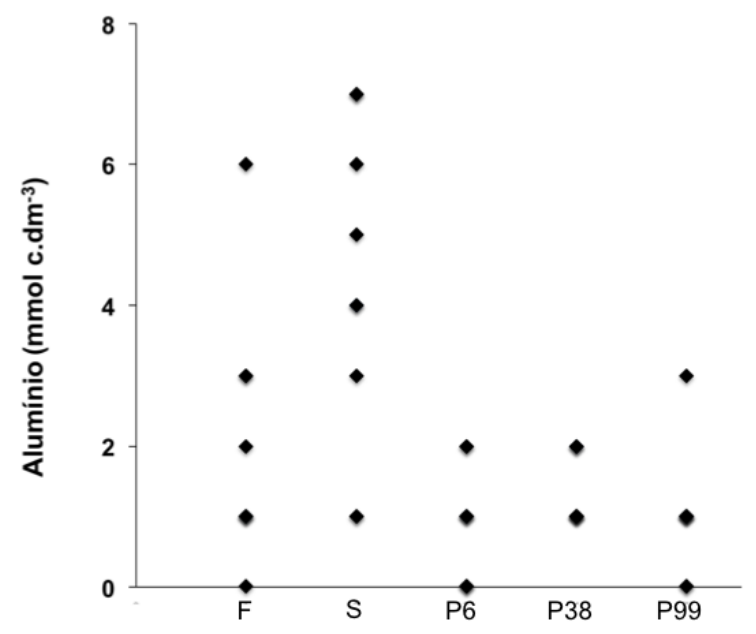

G)

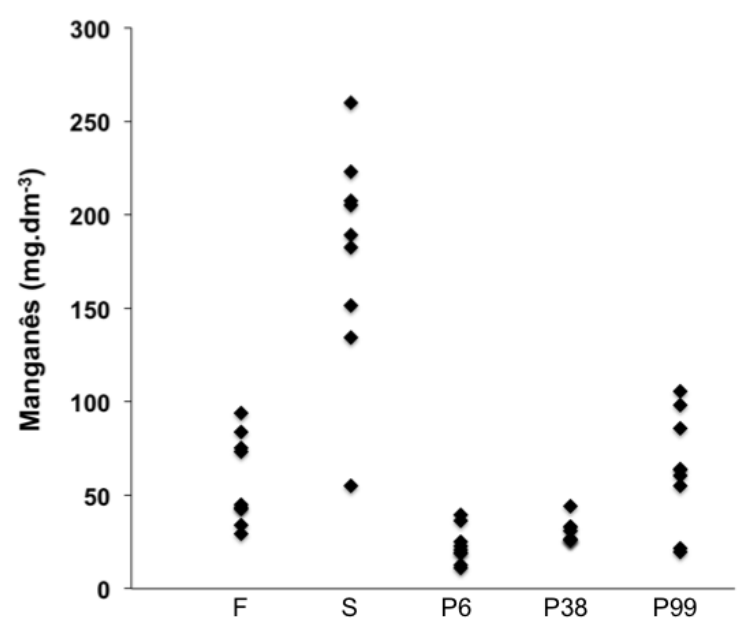

F)

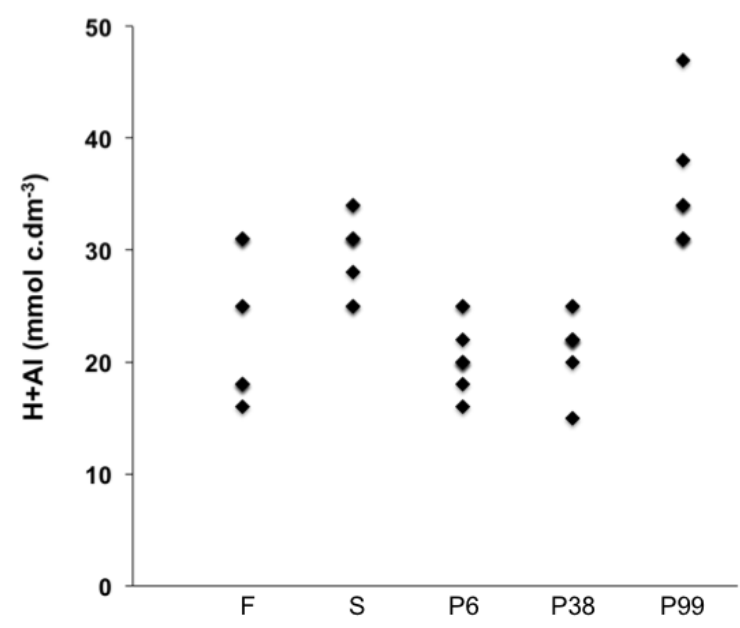

H)

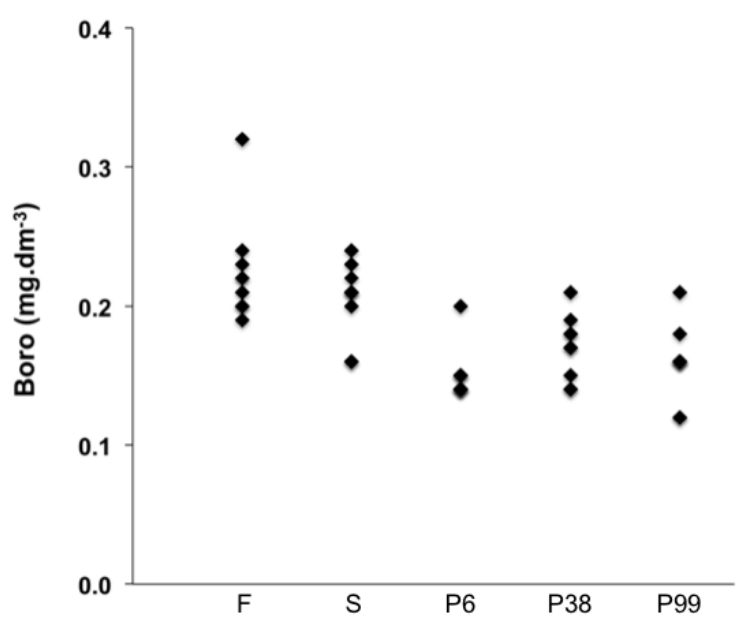


Outros fatores físico-químicos, que não tiveram correlação significativa na análise de envfit, também tiveram valores mais elevados na pastagem P99, quando comparado com as demais pastagens (Figura 14, Tabela 7).

Figura 14. Quantificações de fatores físico-quimicos em amostras de solo da Amazônia. A) Ferro; B) Cobre; C) Magnésio.

A)

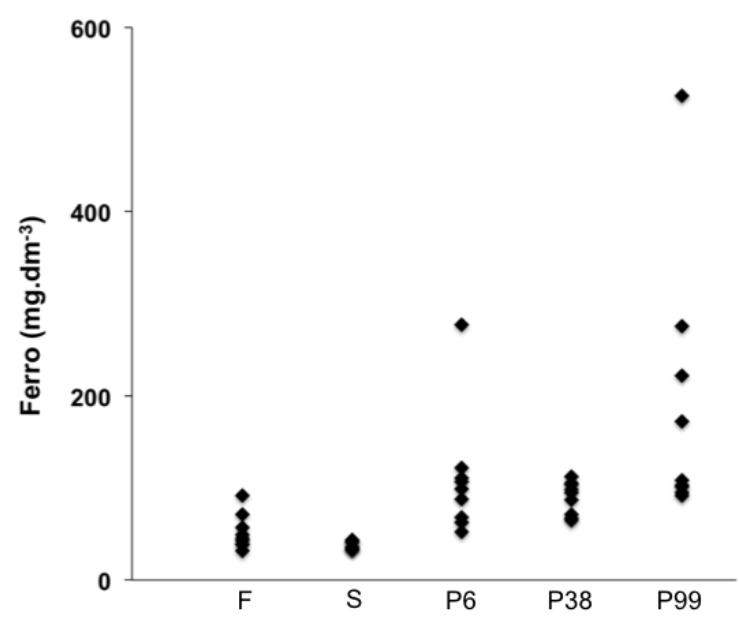

B)

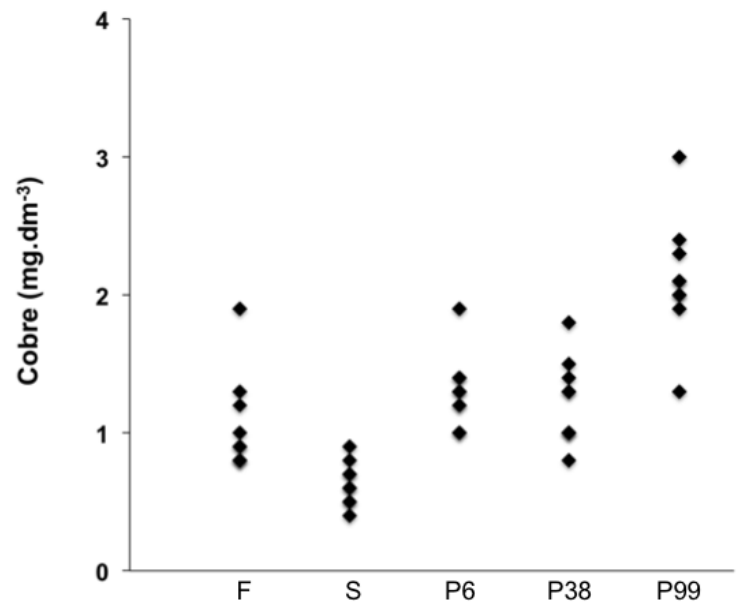

C)

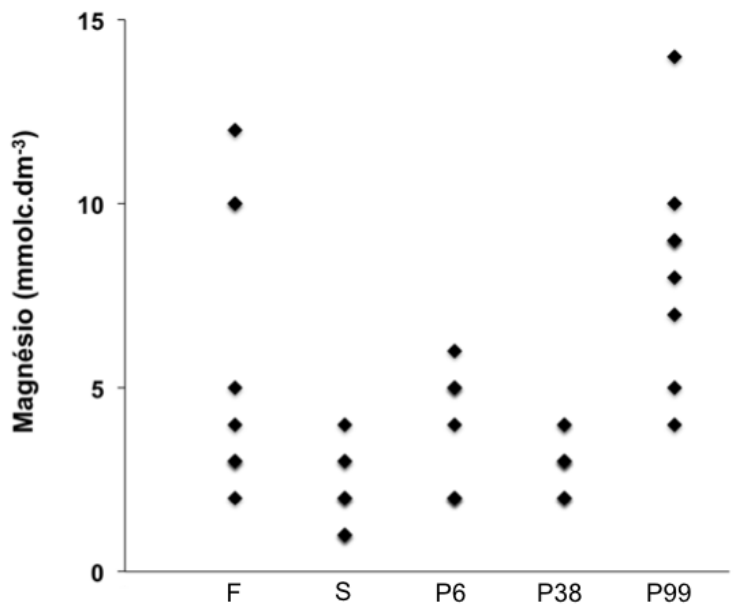




\subsection{Correlação entre a distância espacial e distância Bray-Curtis nos sítios de amostragem}

Para avaliar se as diferenças entre as comunidades de um sítio aumentam com a distância entre os pontos de amostragem, foi realizado o teste de Mantel, que avalia a correlação entre matrizes de distância espacial e ecológica. Em nenhum sítio de amostragem foi observada uma correlação significativa (Tabela 9).

Tabela 9 - Teste de Mantel entre distância geográfica e distância Bray-Curtis.

\begin{tabular}{lcc}
\hline Sítio de amostragem & $\boldsymbol{r}^{\mathbf{a}}$ & $\boldsymbol{p}^{\mathbf{b}}$ \\
\hline Floresta primária & 0,216 & 0,204 \\
Floresta secundária & $-0,093$ & 0,617 \\
Pastagem 6 anos & $-0,293$ & 0,929 \\
Pastagem 38 anos & 0,290 & 0,111 \\
Pastagem 99 anos & 0,045 & 0,404 \\
\hline${ }^{a}$ correlação entre a matriz de dissimilaridade entre pontos de amostragem dentro do sítio e \\
a distância geográfica dos pontos.
\end{tabular}

\subsection{Teste de associação de famílias de genes aos solos submetidos a diferentes formas de uso}

Foi realizado um teste para verificar se genes dos ciclos do carbono e nitrogênio possuem associação com um ou mais solos estudados. Para esse propósito foi empregado o índice de correlação $r_{p b}$ para avaliar a qual sítio ou combinação de sítios cada família de genes se associa mais fortemente. A significância da associação foi checada por teste de permutação. Em seguida, foi realizado um segundo teste, onde foi avaliado a qual sítio único a família de genes se associava mais, e a significância foi novamente testada (Tabela 10 e 11).

No primeiro teste, de 49 famílias de genes analisadas, 43 mostraram associação significativa a um ou mais sítios de amostragem. Apenas uma família de genes associou-se mais fortemente e significativamente a um único sítio: amyX, que codifica para a enzima amylopululanase, relacionada ao processo de degradação de amido, se associou ao sítio P6 (Tabela 11).

Ao avaliar as famílias de genes que se associaram à combinação de dois sítios, uma se associou à combinação das pastagens P6 e P38: gene da 
isopululanase, relacionada ao processo de degradação de amido. Por outro lado, 6 famílias de genes se associaram significativamente à combinação das duas florestas, sendo elas relacionadas aos processos de nitrificação (amoA-AOA amônia monooxigenase de arqueias), redução dissimilatória de $\mathrm{N}$ (nrfA - nitrito redutase), fixação de $N$ (nifH - nitrogenase redutase) (Tabela 10), fixação de $C$ (FTHFS - Formato-tetrahidrofolato ligase e rubisco) e oxidação de metano ( $p m o A-$ metano monooxigenase) (Tabela 11).

A combinação das duas florestas com P99 teve sete famílias de genes associadas, as quais pertencem aos processos funcionais desnitrificação (norB óxido nítrico redutase), redução dissimilativa de $\mathrm{N}$ (napA - nitrato redutase), anammox (hzo - hidrazina oxidoredutase), nitrificação (hao - hidroxilamina oxidoredutase), degradação de hemicelulose (alfa-n-arabinofuranosidase fungi), degradação de amido (cda - ciclomaltodestrina destrina hidrolase e np/T neopululanase). 35 genes relacionados aos mais diversos processos se associaram à combinação $\mathrm{F}+\mathrm{S}+\mathrm{P} 38+\mathrm{P} 99$.

No teste de associação a sítios únicos, onde combinações de ambientes não foram consideradas, 36 famílias de genes se associaram significativamente a um dos ambientes estudados. Duas famílias se associaram à pastagem P6, cinco à floresta primária e 29 à floresta secundária. Nenhuma família de gene se associou significativamente a P38 ou a P99 individualmente (Tabelas 10 e 11). 
Tabela 10 - Análise de associação de famílias de genes relacionados ao ciclo do N. Para cada família de genes está sendo mostrado o sítio ou a combinação de sítios com o qual houve maior associação, bem como os sítios individuais que apresentaram maiores índices.

\begin{tabular}{|c|c|c|c|c|}
\hline \multirow{2}{*}{$\begin{array}{l}\text { Processos } \\
\text { funcionais / } \\
\text { famílias de genes }\end{array}$} & \multicolumn{2}{|c|}{$\begin{array}{c}\text { Teste de associação a sítio ou } \\
\text { combinação de sítios }^{\mathrm{a}}\end{array}$} & \multicolumn{2}{|c|}{$\begin{array}{l}\text { Teste de associação a } \\
\text { sítios únicos }\end{array}$} \\
\hline & Combinação de sítios & Índice $\left(r_{p b}\right)$ & Sítio & Índice $\left(r_{p b}\right)$ \\
\hline \multicolumn{5}{|l|}{ Ciclo do Nitrogênio } \\
\hline \multicolumn{5}{|l|}{ Nitrificação } \\
\hline amoA_AOA & $F+S$ & $0.659^{* *}$ & $S$ & $0.473^{* *}$ \\
\hline hao & $F+S+P 99$ & $0.421^{\star}$ & $\mathrm{F}$ & 0.266 \\
\hline amoA_AOB & $F+S+P 38+P 99$ & $0.714^{\star \star}$ & $\mathrm{S}$ & $0.449^{* *}$ \\
\hline \multicolumn{5}{|l|}{ Anammox } \\
\hline$h z o$ & $F+S+P 99$ & $0.370^{*}$ & $S$ & 0.218 \\
\hline \multicolumn{5}{|l|}{ Red. Dissim. N } \\
\hline$n r f A$ & $F+S$ & $0.532^{\star *}$ & $\mathrm{~F}$ & $0.328^{*}$ \\
\hline napA & $F+S+P 99$ & $0.571^{* *}$ & $S$ & $0.332^{*}$ \\
\hline narG & $F+S+P 38+P 99$ & $0.436^{\star \star}$ & $\mathrm{S}$ & $0.320^{*}$ \\
\hline \multicolumn{5}{|l|}{ Desnitrificação } \\
\hline nor $B$ & $F+S+P 99$ & $0.631^{\star *}$ & $S$ & $0.446^{\star *}$ \\
\hline nirk & $F+S+P 38+P 99$ & $0.629^{* *}$ & $S$ & $0.367^{\star}$ \\
\hline nirs & $F+S+P 38+P 99$ & $0.474^{* *}$ & $S$ & $0.315^{\star}$ \\
\hline nos $Z$ & $F+S+P 38+P 99$ & $0.601^{\star *}$ & $\mathrm{~S}$ & $0.373^{\star \star}$ \\
\hline \multicolumn{5}{|l|}{ Amonificação } \\
\hline ureC & $F+S+P 38+P 99$ & $0.770^{* *}$ & $\mathrm{~S}$ & $0.402^{\star \star}$ \\
\hline$g d h$ & $F+S+P 38+P 99$ & $0.636^{\star *}$ & $\mathrm{~S}$ & $0.349^{*}$ \\
\hline \multicolumn{5}{|l|}{ Red. Assim. N } \\
\hline nirB & $\mathrm{S}$ & 0.302 & $\mathrm{~S}$ & $0.302^{*}$ \\
\hline nas $A$ & $F+S+P 38+P 99$ & $0.495^{\star *}$ & $S$ & $0.325^{\star}$ \\
\hline nirA & $S+P 6+P 38+P 99$ & 0.240 & P38 & 0.214 \\
\hline \multicolumn{5}{|c|}{ Fixação de Nitrogênio } \\
\hline nifH & $F+S$ & $0.511^{* *}$ & $S$ & $0.392^{\star *}$ \\
\hline \multicolumn{5}{|c|}{$\begin{array}{l}\text { teste de associação a um sítio ou a uma combinação de sítios; }{ }^{b} \text { teste de associação a um } \\
\text { dos sítios independentemente. } r_{b p} \text { : índice de correlação; } \mathrm{F}: \text { floresta primária; S: floresta } \\
\text { secundária; P6: pastagem de } 6 \text { anos; P38: pastagem de } 38 \text { anos; P99: pastagem de } 99 \\
\text { anos. }{ }^{*} p<0,05 ;{ }^{*} p<0,01 \text {. } \\
\text { Enzimas codificadas pelos genes: } \\
\text { amoA: amônia monooxigenase; hao: hidroxilamina oxidoredutase; hzo: hidrazina } \\
\text { oxidoredutase; narG e napA: nitrato redutase; nrfA: nitrito resutase; norB: óxido nítrico } \\
\text { redutase; nirK e nirS: nitrito redutase; nosZ: óxido nitroso redutase; ureC: urease; gdh } \\
\text { glutamato desidrogenase; nirB e nirA: nitrito redutase; nas } A \text { : nitrato redutase; nifH } \\
\text { nitrogenase redutase. }\end{array}$} \\
\hline
\end{tabular}


Tabela 11 - Análise de associação de famílias de genes relacionados ao ciclo do C. Para cada família de genes está sendo mostrado o sítio ou a combinação de sítios com o qual houve maior associação, bem como os sítios individuais que apresentaram maiores índices.

\begin{tabular}{|c|c|c|c|c|}
\hline \multirow{2}{*}{$\begin{array}{l}\text { Processos } \\
\text { funcionais / } \\
\text { famílias de genes }\end{array}$} & \multicolumn{2}{|c|}{$\begin{array}{c}\text { Teste de associação a sítio ou } \\
\text { combinação de sítios }^{\text {a }}\end{array}$} & \multicolumn{2}{|c|}{$\begin{array}{c}\text { Teste de associação a } \\
\text { sítios únicos }^{\mathfrak{b}}\end{array}$} \\
\hline & Combinação de sítio & Índice $\left(r_{\mathrm{pb}}\right)$ & Sítio & Índice $\left(\mathrm{r}_{\mathrm{pb}}\right)$ \\
\hline \multicolumn{5}{|l|}{ Ciclo do Carbono } \\
\hline \multicolumn{5}{|c|}{ Degradação de C - Amido } \\
\hline amyX & P6 & $0.434^{* *}$ & P6 & $0.434^{* *}$ \\
\hline isopululanase & $P 6+P 38$ & $0.442^{\star \star}$ & P6 & $0.349^{*}$ \\
\hline cda & $F+S+P 99$ & $0.585^{\star \star}$ & $\mathrm{F}$ & $0.329^{*}$ \\
\hline$n p / T$ & $F+S+P 99$ & $0.499^{* \star}$ & $\mathrm{S}$ & 0.234 \\
\hline amyA & $F+S+P 38+P 99$ & $0.674^{* *}$ & $\mathrm{~S}$ & $0.334^{*}$ \\
\hline apu & $F+S+P 38+P 99$ & $0.784^{\star \star}$ & $\mathrm{S}$ & $0.387^{\star \star}$ \\
\hline glucoamilase & $F+S+P 38+P 99$ & $0.422^{*}$ & $\mathrm{~S}$ & 0.260 \\
\hline \multicolumn{5}{|c|}{ Degradação de C - Celulose } \\
\hline $\mathrm{CDH}$ & $F+S+P 38+P 99$ & $0.841^{* \star}$ & $\mathrm{S}$ & $0.397^{\star \star}$ \\
\hline celobiase & $F+S+P 38+P 99$ & $0.676^{\star *}$ & $\mathrm{~F}$ & $0.318^{*}$ \\
\hline endoglucanase & $F+S+P 38+P 99$ & $0.746^{\star *}$ & $\mathrm{~S}$ & $0.385^{\star *}$ \\
\hline exoglucanase & $F+S+P 38+P 99$ & $0.603^{* *}$ & $\mathrm{~S}$ & 0.269 \\
\hline \multicolumn{5}{|c|}{ Degradação de C - Hemicelulose } \\
\hline ara fungi & $F+S+P 99$ & $0.693^{\star *}$ & $\mathrm{~S}$ & $0.427^{\star \star}$ \\
\hline ara & $F+S+P 38+P 99$ & $0.649^{* *}$ & $\mathrm{~S}$ & $0.365^{\star *}$ \\
\hline mananase & $F+S+P 38+P 99$ & $0.708^{* *}$ & $\mathrm{~F}$ & $0.426^{\star *}$ \\
\hline$x y \mid A$ & $F+S+P 38+P 99$ & $0.662^{\star *}$ & $S$ & $0.355^{\star *}$ \\
\hline xilanase & $F+S+P 38+P 99$ & $0.549 * *$ & $S$ & 0.289 \\
\hline \multicolumn{5}{|c|}{ Degradação de C - lignina } \\
\hline Fenol oxidase & $F+S+P 38+P 99$ & $0.496^{\star *}$ & $\mathrm{~S}$ & $0.309^{*}$ \\
\hline$g / x$ & $F+S+P 38+P 99$ & $0.582^{\star \star}$ & $S$ & $0.349^{* \star}$ \\
\hline lip & $F+S+P 38+P 99$ & $0.459^{* *}$ & $\mathrm{~S}$ & 0.273 \\
\hline$m n p$ & $F+S+P 6+P 38$ & 0.280 & $\mathrm{~S}$ & 0.250 \\
\hline \multicolumn{5}{|c|}{ Degradação de C - Pectina } \\
\hline pectinase & $\mathrm{F}+\mathrm{S}$ & 0.180 & $\mathrm{~S}$ & 0.162 \\
\hline \multicolumn{5}{|c|}{ Degradação de C - Quitina } \\
\hline acetilglucosaminidase & $F+S+P 38+P 99$ & $0.568^{* *}$ & $\mathrm{~S}$ & $0.349^{*}$ \\
\hline endoquitinase & $F+S+P 38+P 99$ & $0.701^{* \star}$ & $\mathrm{S}$ & $0.321^{*}$ \\
\hline exoquitinase & $F+S+P 38$ & 0.364 & P38 & 0.173 \\
\hline \multicolumn{5}{|l|}{ Fixação de Carbono } \\
\hline rubisco & $F+S$ & $0.493^{* *}$ & $S$ & $0.386^{\star *}$ \\
\hline FTHFS & $\mathrm{F}+\mathrm{S}$ & $0.501^{* *}$ & $\mathrm{~F}$ & $0.326^{*}$ \\
\hline$a c / B$ & $F+S+P 38+P 99$ & $0.770^{\star \star}$ & $\mathrm{S}$ & $0.385^{\star \star}$ \\
\hline $\mathrm{CODH}$ & $F+S+P 38+P 99$ & $0.616^{\star *}$ & $S$ & $0.348^{\star *}$ \\
\hline \multicolumn{4}{|l|}{ Oxidação de Metano } & $0.338^{* *}$ \\
\hline$p m o A$ & $\mathrm{~F}+\mathrm{S}$ & $0.493^{* *}$ & $S$ & $0.373^{*}$ \\
\hline $\operatorname{mmoX}$ & $F+S+P 38+P 99$ & $0.553^{\star \star}$ & $S$ & 0.290 \\
\hline \multicolumn{5}{|l|}{ Produção de Metano } \\
\hline$m c r A$ & $F+S+P 38$ & 0.266 & $\mathrm{~S}$ & 0.205 \\
\hline
\end{tabular}


${ }^{a}$ teste de associação a um sítio ou a uma combinação de sítios; ${ }^{b}$ teste de associação a um dos sítios independentemente. $r_{b p}$ : índice de correlação; F: floresta primária; S: floresta secundária; P6: pastagem de 6 anos; P38: pastagem de 38 anos; P99: pastagem de 99 anos. ${ }^{*} p<0,05 ;{ }^{* *} p<0,01$.

Enzimas codificadas pelos genes:

amyX e apu: amylopululanase; amyA: alfa amilase; cda: ciclomaltodestrina destrina hidrolase; $n p / T$ : neopululanase; glx: glioxal oxidase; lip: manganese peroxidase; mnp: lignina peroxidase; ara: alfa-n-arabinofuranosidase; FTHFS: Formato-tetrahidrofolato ligase; aclB: succinil-CoA sintetase; $\mathrm{CODH}$ : monóxido de carbono desidrogenase: pcc: propionil-CoA carboxilase; $p m o A$ e mmoX: metano monooxigenase particulada e solúvel; mcrA: metil coenzima M redutase. 


\section{DISCUSSÃO}

\subsection{Diversidade de genes funcionais em solos da Amazônia submetidos a diferentes formas de uso.}

A riqueza de genes funcionais revela a diversidade metabólica contida no genoma de uma comunidade. Embora a presença do gene não signifique que a função a ele relacionada esteja sendo executada, uma maior riqueza funcional indica maior versatilidade metabólica em potencial. O emprego da técnica do Geochip possibilitou avaliar, de forma qualitativa e quantitativa, a diversidade de genes presentes na área de estudo. Uma riqueza de mais de 66 mil genes, pertencentes a 409 famílias foi revelada. Genes pertencentes a todos os processos funcionais presentes no Geochip foram detectados (Tabela 3).

Nos solos avaliados, a riqueza de genes foi alterada com a mudança na forma de seu uso. A conversão de floresta a pastagem promoveu uma redução no número de genes, que foi restabelecido com o crescimento da floresta secundária. $\mathrm{Na}$ pastagem P99 foi encontrada riqueza similar às florestas (Figura 9A). Como apresentado nos métodos, dados de trabalhos anteriores (DE MORAES et al., 1996; HERPIN et al., 2002), apontam que P99 possui diferentes característica em relação aos demais sítios. Embora não seja considerada parte da cronosequência, esta pastagem foi incluída nas análises e seus resultados serão discutidos a seguir, juntamente com as variáveis ambientais.

A riqueza é considerada uma medida robusta da diversidade biológica. Entretanto, a diversidade também pode ser acessada por meio de diferentes índices, sendo alguns mais popularmente conhecidos e amplamente empregados, como o Shannon-Weaver $\left(H^{\prime}\right)$. Este baseia-se na riqueza e na uniformidade da abundância das espécies (MAGURRAN, 2004). O índice foi aplicado com o intuito de comparar a diversidade funcional entre sítios e revelou um perfil muito semelhante ao observado para a riqueza, com redução nas pastagens em relação às florestas (Tabela 4). Analisando este parâmetro, verifica-se que a diversidade de genes funcionais do solo na Amazônia responde à conversão da floresta a pastagem diferentemente da diversidade taxonômica. Isso pode ser concluído ao comparar os resultados do Geochip com os dados obtidos por Jesus et al. (2009) que, analisando o gene 16S rRNA, verificou que a diversidade na pastagem é maior que na floresta. Resultados 
divergentes entre estudos avaliando 16SrRNA e genes funcionais já foram relatados anteriormente na Amazônia (TAKETANI; TSAI, 2010). Isso ressalta a importância de estudar genes funcionais envolvidos nos processos de interesse, pois esses podem revelar padrões diferentes daqueles observados para análises taxonômicas.

O Geochip possui uma variedade de sondas para cada família de genes e essas sondas são, muitas vezes, desenhadas para sequências provenientes de diferentes micro-organismos. Apesar da pequena variação na riqueza de famílias (Figura 9B), o aumento do número de genes em alguns sítios sugere a presença de uma maior riqueza de genes para a mesma função, e consequentemente, um maior número de micro-organismos com redundância funcional. Entretanto, a extrapolação dos resultados obtidos para um contexto taxonômico deve ser vista com cautela, considerando a falta de conhecimento sobre a correlação entre a diversidade taxonômica e a variação das sequências dos genes funcionais. Por outro lado, correlação entre a riqueza de um gene funcional e a estabilidade da função já foi demonstrada anteriormente (LEVINE et al., 2011). Dessa forma, os sítios com maior riqueza de genes para a mesma função estariam menos susceptíveis a situações que possam gerar oscilações no processo relacionado.

\subsection{Estrutura funcional da comunidade microbiana em solos da Amazônia submetidos a diferentes formas de uso}

Uma das grandes vantagens de utilização de tecnologias de microarranjos de DNA para analisar a diversidade de genes funcionais é a possibilidade de estudar a estrutura de uma comunidade baseada em vários genes. Esta abordagem, além de revelar as diferenças entre as amostras quanto ao potencial funcional, permite fazer comparações entre estrutura funcional e estrutura taxonômica da comunidade, abrangendo os mais diferentes grupos.

Uma das hipóteses do presente trabalho é que a estrutura funcional da comunidade seja alterada com o uso do solo, de maneira semelhante ao observado para a estrutura taxonômica (JESUS et al., 2009), pois isso justificaria as mudanças nos processos funcionais ligados à microbiota do solo, relatadas anteriormente (DE MORAES et al., 1996; STEUDLER et al., 1996; NEILL et al., 1997).

Para testar esta hipótese foram utilizadas matrizes de abundância dos genes e empregados diferentes métodos de análises multivariadas. Resultados da análise 
de NMDS (Figura 10), confirmados pelo teste de ANOSIM (Tabela 6), mostram que as comunidades das pastagens P6 e P38 estão claramente separadas das florestas primária e secundária, sendo que estas encontram-se agrupadas. Interessantemente, a pastagem P99, também teve a maioria das amostras agrupadas com as florestas. De acordo com estes resultados, ao considerar apenas os quatro sítios com o mesmo tipo de solo (F, P6, P38 e S), a hipótese se confirma, pois a estrutura funcional da comunidade é alterada pela mudança no uso do solo e tende a se restaurar com o crescimento da floresta secundária. Adicionalmente, foi verificado que o tempo de uso da pastagem também foi um fator importante, pois foram observadas diferenças entre P6 e P38.

$\mathrm{Na}$ análise de agrupamento (Figura 11) foram observadas algumas diferenças em relação ao NMDS. P6 ainda foi o sítio que mostrou um perfil mais diferenciado, porém amostras de P38 e P99 também se posicionaram em seu grupo. Formou-se um agrupamento somente com florestas (parte superior da figura), porém algumas amostras, principalmente de floresta secundária, se distribuíram pelo dendrograma, misturadas com amostras de P38 e P99. Embora haja uma sobreposição no centro da figura, nesta análise verifica-se uma tendência de separação entre florestas (parte superior) e pastagens (parte inferior).

As diferenças observadas nas duas análises podem ser devido a dois fatores principais. Primeiramente, os métodos de distância escolhidos foram diferentes. Para o NMDS foi empregado o Bray-Curtis (CLARKE, 1993), que enfatiza as diferenças em abundância de cada espécie (neste caso, cada gene), sofrendo grande influência de dominantes (KINDT; COE, 2005). Já a análise de agrupamento foi feita com distância Euclidiana. Esta usa as espécies (processos funcionais, neste caso) como eixos e então plota os sítios, de acordo com a abundância de cada espécie. A distância euclidiana entre dois sítios é a distância linear entre eles neste gráfico. Outra característica da distância euclidiana é o fato de sofrer grande influência da abundância total (KINDT; COE, 2005). O segundo fator que pode ter influenciado nas diferenças entre as análises é a forma de agrupamento dos dados. Para a análise de NMDS foi utilizada uma matriz com as abundâncias de famílias de genes, enquanto que o "heatmap" (com análise de agrupamento), foi construído baseado na abundância total de cada processo funcional, e portanto a agregação dos dados pode ter reduzido o nível de informação avaliada, mascarando pequenas diferenças existentes entre as amostras. Por outro lado, a análise de "heatmap" 
possui grande relevância, por permitir observar os perfis funcionais das amostras, e revelou que há variações nas abundâncias dos grupos de genes entre as amostras (linhas), assim como diferenças nos perfis de coloração entre os processos (colunas). Para alguns processos funcionais, principalmente anammox, houve uma grande variação na abundância de genes, apresentando notável diferença ao comparar com os demais perfis. Por outro lado, menor variação na abundância foi observada para outros processos, como degradação de $\mathrm{C}$ e fixação de $\mathrm{C}$. Essas diferenças mostram que o Geochip é eficiente para caracterizar comunidades, detectando variações entre processos funcionais.

O efeito de mudanças no uso do solo na Amazônia sobre alguns grupos microbianos funcionais já foi demostrado anteriormente. Taketani e Tsai (2010) apontaram o manejo como um fator mais importante que o tipo de solo para a estrutura de comunidades de arqueias oxidadoras de amônia (AOA), revelada por análises do gene amoA. É interessante notar que análises realizadas no mesmo trabalho com genes 16S rRNA de arqueias, revelaram o oposto, onde houve mais influência do tipo de solo do que da forma de uso.

Alterações na estrutura funcional de comunidades microbianas devido a mudanças no uso do solo já foram descritas para outros ambientes empregando o Geochip. Ao avaliar solos com diferentes formas de manejo, Reeve et al. (2010) apontaram o manejo como um fator mais importante que o tipo de solo influenciando

a estrutura funcional da comunidade. Empregando o Geochip 2.0 para avaliar os efeitos do reflorestamento sobre a diversidade de genes funcionais, Berthrong et al. (2009) verificaram alteração da estrutura funcional da comunidade e redução na abundância de genes importantes para processos biogeoquímicos.

\subsection{Influência dos fatores ambientais sobre a estrutura funcional da comunidade microbiana}

Mudanças na forma de uso do solo frequentemente são acompanhadas por alterações de suas propriedades. Na fazenda Nova Vida, a retirada da vegetação natural e o estabelecimento de pastagens promovem mudanças de características do solo, como porosidade, $\mathrm{pH}$, e quantidade de nutrientes disponíveis (DE MORAES et al., 1996). 
As propriedades do solo estão entre os principais fatores guiando a estrutura taxonômica e funcional de comunidades microbianas (WAKELIN et al., 2008; JESUS et al., 2009; ENWALL et al., 2010; REEVE et al., 2010; KURAMAE et al., 2011).

Para procurar por características do solo com influência sobre a composição e abundância de genes funcionais nos ambientes estudados, foram quantificadas 24 variáveis físico-químicas, as quais foram testadas quanto às suas correlações com a estrutura funcional da comunidade por meio do teste envfit. Além disso, uma avaliação mais detalhada dos valores das variáveis que tiveram correlação significativa no envfit foi realizada, com o intuito de checar quais pontos realmente guiaram a disposição dos vetores.

Analisar as características do solo do local de forma aprofundada está além do escopo deste trabalho e, como citado anteriormente, já existe uma vasta bibliografia sobre o assunto (DE MORAES et al., 1996; NEILL et al., 1997; FERNANDES et al., 2002; HERPIN et al., 2002). Desta forma, aqui serão discutidas principalmente as variáveis que apresentaram correlação significativa no teste realizado.

De acordo com a análise envfit (Figura 12), maiores quantidades de matéria orgânica, carbono e nitrogênio tiveram relação com pastagem P38 e algumas amostras de P99. Porém, verificou-se que os pontos de P99 que se separam do restante das amostras deste sítio, e que estão correlacionados com C, N e MO no NMDS, correspondem aos pontos com altas concentrações dessas variáveis na Figura 13. Além disso, as amostras de P38 não possuem concentrações elevadas de $\mathrm{MO}, \mathrm{C}$ e N, quando comparadas com as amostras dos demais sítios. Isso sugere que a disposição desses vetores é influenciada principalmente pelos dois pontos de P99.

Além das diferenças nas quantidades de $\mathrm{C}, \mathrm{N}$ e MO, a pastagem P99 também apresentou valores significativamente maiores de $\mathrm{P}, \mathrm{H}+\mathrm{Al}, \mathrm{Cu}, \mathrm{Mg}$ e $\mathrm{T}$, quando comparada com as demais pastagens $(p<0,05)$ (Figuras 13 e 14). As diferenças encontradas em P99 concordam com De Moraes et al. (1996), que caracterizaram o solo desta pastagem como diferente dos demais. Herpin et al. (2002) também encontraram valores mais elevados de macro e micro nutrientes em P99, comparando com outras pastagens da região e, de acordo com os autores, P99 se distingue das demais pastagens, tanto por suas propriedades minerais, quanto pelo manejo inicial diferenciado. Devido às diferentes características do solo desta 
pastagem, os resultados obtidos para P99 foram utilizados neste trabalho apenas com a finalidade de descrever a diversidade funcional contida em um solo utilizado como pastagem por quase 100 anos na região Amazônica. Entretanto, não é possível determinar quais alterações na microbiota são explicadas pela forma de uso do solo e quais são devido ao tipo de solo e, portanto, esta pastagem não foi considerada parte da cronosequência.

Diversos trabalhos realizados na Amazônia relataram aumento nas quantidades de $\mathrm{C}$ e $\mathrm{N}$ após a conversão de floresta a pastagem (DE MORAES et al., 1996; HERPIN et al., 2002; CENCIANI et al., 2009). Entretanto, em outros estudos não foram encontrados os mesmos resultados. Nas cronosequências avaliadas por Neill et al. (1997), o aumento de C e $N$ não foi significativo para a maioria das pastagens, sendo que em alguns casos foi observada até uma redução. Os autores apontam variações entre solos e tipo de manejo como possíveis responsáveis pelas diferenças entre estudos. De forma semelhante, no presente trabalho não foram verificadas alterações significativas nos conteúdos de $\mathrm{C}$ e $\mathrm{N}$ entre as florestas e as pastagens P6 e P38. A matéria orgânica também não variou entre a floresta primária e as pastagens P6 e P38, mas foi constatada redução significativa na floresta secundária, comparando com as pastagens (Tabela 7; Figura 13 A, B e C)

A conversão de floresta para pastagem na Amazônia é frequentemente acompanhada por aumento no pH do solo (DE MORAES et al., 1996; BORNEMAN; TRIPLETT, 1997; HERPIN et al., 2002; CENCIANI et al., 2009), apesar de resultados diferentes já terem sido observados (ERICKSON; KELLER; DAVIDSON, 2001). Neste trabalho foi observada apenas uma pequena variação do pH entre solos avaliados (4.0 a 4.3 nas florestas e 4.5 a 4.7 nas pastagens), não havendo aumento significativo nas pastagens em relação à floresta primária. Entretanto o pH da floresta secundária foi significativamente menor que os valores observados nas três pastagens (Tabela 7). $\mathrm{O} \mathrm{pH}$ tem sido considerado um importante fator influenciando estrutura e função de comunidades microbianas em diferentes ambientes (FIERER; JACKSON, 2006; WAKELIN et al., 2008; JESUS et al., 2009). Porém, neste trabalho não foi encontrada correlação significativa entre o $\mathrm{pH}$ e a estrutura funcional da comunidade (Tabela 8; Figura 12), o que provavelmente se deve à pequena oscilação desta variável entre as amostras.

Embora o $\mathrm{pH}$ não tenha tido correlação significativa, foi verificada influência de outras variáveis ligadas à acidez do solo (Tabela 8; Figura 12). As florestas foram 
relacionadas com maior acidez potencial $(\mathrm{H}+\mathrm{Al})$ e maior concentração de alumínio, semelhante ao encontrado por outros autores (CENCIANI et al., 2009; JESUS et al., 2009). Diferenças significativas nos valores de $\mathrm{Al}$ e $\mathrm{H}+\mathrm{Al}$ foram observadas ao comparar floresta secundária com P6 e P38, e com a floresta primária (Tabela 7; Figura 13), diferentemente do encontrado por Cenciani et al.. É interessante notar que P99 também apresentou altos valores de $\mathrm{H}+\mathrm{Al}$.

Maiores concentrações de boro e manganês tiveram correlação principalmente com as comunidades funcionais das florestas (Figura 12), o que foi confirmado pelas maiores quantidades desses elementos nesses sítios (Tabela 7; Figura 13). Esses resultados foram diferentes do esperado, já que a conversão de floresta a pastagem na região é geralmente acompanhada de um aumento de micronutrientes (HERPIN et al., 2002).

A disponibilidade de fósforo é um fator ambiental importante para a comunidade microbiana do solo. Kuramae et al. (2011) demonstraram que a abundância de grupos taxonômicos e a estrutura da comunidade em solos em recuperação de atividade agrícola teve grande influência da quantidade de $P$ disponível. A análise de envfit indicou que uma maior concentração deste elemento teve relação com as comunidades das florestas (Figura 12). Em uma primeira análise não foi observada variação significativa na quantidade de $P$ entre os sítios com o mesmo tipo de solo (Tabela 7). Entretanto, ao excluir P99 do teste de ANOVA, observou-se as seguintes alterações: a conversão de floresta a pastagem promoveu uma redução significativa da concentração de P; a floresta secundária teve um aumento em relação a P6. Ao analisar florestas e pastagens de diferentes idades na Amazônia, Neill et al. (1997) encontraram uma grande variação na concentração de $\mathrm{P}$ nas pastagens, algumas sendo comparáveis às concentrações das florestas. Assim como verificado no presente trabalho, Fernandes et al. (2002) também encontraram maiores concentrações de $P$ em florestas na Fazenda Nova Vida. Entretanto, o grupo de Fernandes relatou uma redução da concentração de $P$ com o aumento da idade da pastagem, que não foi encontrado aqui. De acordo com os autores, a redução da disponibilidade de $P$ inorgânico seguindo a conversão da floresta a pastagem pode ser explicada pela imobilização do elemento pelas folhas e raízes das gramíneas e incorporação pela biomassa microbiana. 


\subsection{Influência da distância espacial sobre a diferença entre dois pontos de amostragem}

Trabalhos desenvolvidos recentemente indicam que, ao contrário de uma disposição randômica, os micro-organismos do solo possuem um padrão de distribuição espacial em diferentes escalas (HORNER-DEVINE; CARNEY; BOHANNAN, 2004). Assim como grupos taxonômicos, a disposição de genes funcionais no solo já foi avaliada (GREEN; BOHANNAN; WHITAKER, 2008; ZHOU et al., 2008; HALLIN et al., 2009; ENWALL et al., 2010). Zhou et al. (2008) empregaram o Geochip para analisar a relação entre área e riqueza de genes. Os autores verificaram que, em um quadrante de $500 \mathrm{~m}^{2}$, o aumento da área promoveu o aumento significativo do número de genes de diferentes grupos.

Uma forma de avaliar se os micro-organismos do solo seguem um padrão de distribuição é verificando se as comunidades adjacentes são mais similares entre si do que comunidades mais afastadas (GREEN; BOHANNAN, 2006).

O sistema de amostragem empregado, com pontos distanciando entre si de 0,1 a $100 \mathrm{~m}$, permitiu avaliar a distribuição espacial dos genes funcionais. O método empregado para este propósito foi o teste de Mantel, que verifica se há correlação entre a distância espacial e a dissimilaridade entre os pontos. Para todos os sítios de amostragem, não houve correlação significativa (Tabela 9), sugerindo que para esta escala, e para os esforços de amostragem e técnica empregados, não é possível detectar um padrão de distribuição dos genes funcionais na Amazônia.

Resultados preliminares obtidos por nosso grupo de pesquisa mostraram que para os grupos taxonômicos, em escala de 0,1 a $10.000 \mathrm{~m}$, foi observado que o aumento da distância entre dois pontos é acompanhado pela redução da similaridade entre eles. Este padrão foi mais marcante em florestas do que em pastagens, mostrando que a conversão de floresta para pastagem promove homogeneização das comunidades bacterianas do solo.

A análise de um maior número de amostras, aumentando a escala espacial, será necessária para verificar se a estrutura funcional segue padrão de distribuição semelhante à estrutura taxonômica. 


\subsection{Associação de genes funcionais aos solos submetidos a diferentes formas de uso}

A grande quantidade de dados gerados pelo método do Geochip permitiu fazer uma avaliação robusta da diversidade de genes funcionais em um ambiente, além de possibilitar a realização de diferentes tipos de análises ecológicas. A cada trabalho publicado com a técnica, novas formas de análise de dados são propostas, com o intuito de explorar cada vez mais os detalhes contidos nas informações disponíveis. Muitas das análises empregadas são adaptações de ecologia de macroorganismos, onde os genes são tratados individualmente, da mesma forma que as espécies. Índices de diversidade e análises multivariadas, por exemplo, são excelentes ferramentas para avaliar a diversidade de genes funcionais e a estrutura funcional da comunidade, respectivamente (HE et al., 2011). Entretanto esses métodos se atêm a análises ecológicas da comunidade como um todo, mascarando diferenças nas respostas de grupos específicos (MAGURRAN, 2004; WEISS; REICE, 2005). Ainda são encontradas limitações no que diz respeito às análises de grupos de genes específicos presentes no Geochip. Devido à complexidade dos dados, estas análises são geralmente reduzidas a médias ou somatórias de intensidades de sinal, ou contagem total (presença/ausência), o que acarreta em perda de informação.

Em ecologia de macro-organismos uma forma de estudar distribuição de espécies em diferentes habitats é empregando índices de espécie indicadora ou índices de associação (DUFRENE; LEGENDRE, 1997). Estes índices podem ser aplicados com diversas finalidades, inclusive para avaliação da "preferência" de espécies por um habitat em relação aos demais. A análise de associação de espécies a ambientes pode revelar suas preferências ecológicas (HARMS et al., 2001), além de ser uma ferramenta importante em estudos de manejo ambiental (LARSEN; BLADT; RAHBEK, 2007). Muitos índices já foram desenvolvidos por vários autores e são amplamente empregados (DUFRENE; LEGENDRE, 1997; BAKKER, 2008; DE CACERES; LEGENDRE, 2009). O índice de correlação $r_{p b}$ permite avaliar se uma espécie possui preferência tanto por um habitat, quanto pela combinação de dois ou mais habitats, levando em consideração presença/ausência nos pontos de amostragem e abundância (DE CACERES; LEGENDRE; MORETTI, 2010). A possibilidade de combinar dois ou mais ambientes gera dados mais 
realísticos, pois muitas vezes uma espécie está presente e abundante de forma similar em mais de um local estudado. Os autores sugerem que a combinação de sítios pode revelar uma melhor definição dos limites de um habitat para aquela espécie.

A busca por genes funcionais em amostras ambientais tem como principal objetivo avaliar a possível presença de micro-organismos que carreguem aqueles genes e que teriam o potencial para realizar as funções relacionadas. Sendo assim, pode-se dizer que procurar por um gene funcional é uma forma indireta de procurar por micro-organismos que possuam este gene. Neste trabalho foi proposta a utilização do índice de associação de espécies para o contexto de genes funcionais, onde famílias de genes de interesse foram testadas quanto à "preferência" por algum dos ambientes estudados. Isso possibilitou explorar os dados mais detalhadamente, considerando presença/ausência e abundância em cada ponto de amostragem, dentro de cada sítio. Desta forma, se um gene funcional tem associação com um sítio (ou combinação de sítios), ele possui elevada abundância em um grande número de amostras deste(s) sítio(s), quando comparado com os demais. Isso indica que aquele ambiente é colonizado mais significativamente por micro-organismos que carregam aqueles genes, comparando com os demais ambientes.

Índices de associação já foram utilizados anteriormente para avaliar a preferência de micro-organismos do solo por ambientes preservados ou impactados (JESUS et al., 2009; DING et al., 2012). Entretanto, para o nosso conhecimento esta é a primeira vez que o índice é empregado no contexto de genes funcionais.

Considerando a importância de avaliar genes funcionais envolvidos em processos ligados à sustentabilidade do solo, e ao balanço de gases do efeito estufa na Amazônia, foram selecionadas para esta análise famílias de genes que codificam para enzimas chave em processos dos ciclos biogeoquímicos do carbono e nitrogênio. Para cada família de genes foi realizado um teste com a seguinte pergunta: a qual o sítio ou combinação de sítios de amostragem a família de genes está mais associada? Em seguida foi então feita uma segunda análise onde a pergunta foi: a qual sítio único a família de genes está mais associada?

O elevado número de famílias de genes funcionais com associação significativa (43 de um total de 49 testados - 88\%) indica que mudanças na forma de uso do solo promovem alterações na presença e abundância de genes importantes 
relacionados aos ciclos do $\mathrm{C}$ e $\mathrm{N}$ (Tabela 10). Esse número foi reduzido para 33 na segunda análise (associação somente a sítios únicos), o que ressalta a importância de utilizar a combinação de sítios, pois genes em abundância semelhante em dois ou mais sítios não apresentarão resultados significativos no teste de sítios individuais. A grande variedade de combinações de sítios obtida nos resultados sugere que os genes pertencentes aos diferentes processos funcionais respondem de forma diferente às mudanças na forma de uso do solo.

No primeiro teste somente uma família de gene se associou significativamente a um único sítio, enquanto que 42 se associaram a combinações de 2 ou mais sítios. Associação de genes funcionais a combinações de sítios pode sugerir duas situações, não mutuamente exclusivas: 1) alguns ambientes oferecem condições similares que favoreçam a colonização de forma semelhante por microorganismos de determinados grupos funcionais; 2) micro-organismos com nichos diferenciados, porém carregando genes da mesma família, colonizam os diferentes ambientes.

Ao analisar genes com preferência para combinações de dois sítios, foi notável o fato que a maioria deles se associaram às duas florestas. Estes são genes importantes, relacionados à fixação de $\mathrm{C}$ e $\mathrm{N}$, nitrificação, degradação de $\mathrm{C}$ e redução de nitrato e sulfato. Isso indica que o potencial genético relacionado à essas funções é semelhante entre esses ambientes, sugerindo um restabelecimento das funções na floresta secundária. Analisando taxas de processos do ciclo do $\mathrm{N}$, Davidson et al. (2007) também demonstrou que a floresta secundária tende a restabelecer funções a níveis semelhantes à floresta primária na Amazônia.

Combinações das duas florestas com a pastagem também resultaram em famílias de genes associadas, sugerindo similaridades na colonização por esses grupos funcionais. Um grande número de famílias de genes associaram-se à combinação de quatro sítios, ou seja, todos menos P6. De acordo com De Caceres et al. (2010), a associação a vários ambientes pode significar mais um efeito negativo dos ambientes excluídos do que uma real associação aos selecionados, já que o índice de correlação empregado leva em consideração a ausência da espécie em um sítio, aumentando a força de associação aos demais. Sendo assim, pode-se dizer que esses genes na verdade possuem associação negativa com P6, o que está de acordo com a menor riqueza de genes encontrada nesta pastagem (Figura 9). 
É interessante notar que genes que na primeira análise se associaram a combinações de florestas com pastagens, na segunda análise sempre se associaram significativamente à floresta primária ou à secundária, sendo a última mais frequente. Embora as combinações desses sítios com pastagens tenham aumentado os valores dos índices de associação, os genes se correlacionam mais com as florestas.

A quantificação de genes funcionais tem sido usada como um parâmetro para prever o potencial funcional de comunidades (MORALES; COSART; HOLBEN, 2010). Dessa forma, os resultados do teste de associação de genes sugerem que as florestas avaliadas possuem um maior potencial funcional, quando comparadas com as pastagens.

Diante da alta diversidade de genes funcionais no solo, a identificação de grupos de genes que respondam de forma diferente às alterações ambientais e que possuam preferências por determinados habitats pode servir como uma ferramenta para descrever os impactos sofridos pelas comunidades microbianas do solo. Assim como já estabelecido para espécies (DE CACERES; LEGENDRE; MORETTI, 2010), consideramos que genes com preferências por determinados habitats podem ser usados como indicadores de mudanças ambientais com maior eficiência que aqueles com grande ubiquidade. Adicionalmente, a análise pode ajudar a descrever as preferencias ecológicas dos grupos funcionais, além de caracterizar os ambientes estudados quanto ao seu potencial funcional. Wessen e Hallin (2011) propõe a utilização de grupos funcionais como bioindicadores para monitoramento do solo, e aqui é proposto o emprego do índice de associação para procurar por genes que respondam a alterações ambientais e que possam servir como bioindicadores.

Conforme já citado anteriormente, embora seja sabido que a presença do gene não significa que a função esteja sendo realizada, correlações entre abundância de genes e respectivas funções já foram demonstradas anteriormente (REEVE et al., 2010). Uma forma de avaliar a eficiência do índice de associação é comparando seus resultados com dados de processos relacionados aos genes estudados. Isso pode revelar o quanto a associação de um gene possui importância do ponto de vista funcional.

Neste trabalho não foram realizadas quantificações de processos microbianos relacionados aos genes funcionais estudados. Entretanto, diferentes grupos de pesquisa têm se dedicado exaustivamente a avaliar processos e produtos dos ciclos 
do carbono e nitrogênio na Amazônia, sendo que muitos desses estudos foram feitos na Fazenda Nova Vida. Apesar de pequenas diferenças entre estudos e de variações sazonais, os perfis encontrados, na maioria das vezes, corroboram entre si, demonstrando robustez nas informações.

A seguir serão apresentados os resultados do teste de associação, separados por processo funcional, para verificar quais famílias de genes respondem às mudanças na forma de uso do solo. Os processos funcionais que tiverem dados de trabalhos anteriores serão discutidos para comparar potencial genético e processo funcional, com o intuito de avaliação do teste.

\subsubsection{Ciclo do Nitrogênio}

Nitrificação

A nitrificação é considerada um processo chave regulando a ciclagem e a perda de nitrogênio em solos de floresta (ISOBE et al., 2011). Possui importância agronômica, pois leva à conversão de $\mathrm{NH}_{3}$, à forma facilmente lixiviada, $\mathrm{NO}_{3}$, reduzindo a disponibilidade de $\mathrm{N}$ para as plantas. É também de relevância ambiental, devido à possibilidade de contaminação de água com $\mathrm{NO}_{3}{ }^{-}$. Além disso, a nitrificação no solo é uma fonte de $\mathrm{N}_{2} \mathrm{O}$ para a atmosfera, um potente gás do efeito estufa (WESSEN; HALLIN, 2011).

A primeira etapa do processo consiste na oxidação de amônia a nitrito por bactérias $(A O B)$ ou arqueias $(A O A)$ oxidadoras de amônia, sendo este considerado o passo limitante da nitrificação (ZEGLIN et al., 2011). O Geochip 4.0 possui sondas para dois genes envolvidos neste processo: o gene amoA, que codifica a enzima amônia monooxigenase, responsável pela oxidação da amônia a hidroxilamina; e o gene hao, que codifica hidroxilamina oxidoredutase, responsável por oxidar hidroxilamina a nitrito.

Genes amoA de AOA se associaram significativamente às florestas primária e secundária, enquanto que os genes de $A O B$ foram menos seletivos, distribuindo-se de forma semelhante pelas duas florestas e pelas pastagens P38 e P99. Diferentes respostas desses dois grupos seguindo alterações ambientais já foram relatadas anteriormente (WESSEN et al., 2011), e provavelmente, devido aos diferentes 
nichos desses grupos, fatores ambientais afetam suas comunidades de forma diversa (ZEGLIN et al., 2011).

A família de gene hao se associou à combinação das duas florestas com P99, sendo a floresta primária o sítio com maior índice. Apesar de todas as sequências para este gene no Geochip serem de bactérias oxidadoras de amônia, foram encontradas diferenças nos resultados de associação de hao e amoA-AOB. Yergeau et al. (2007) também não encontraram correlação entre genes hao e amoA-AOB ao empregar o Geochip em amostras da Antártica. As diferenças nos resultados dessas famílias de genes estreitamente relacionadas pode ser devido à falta de cobertura das sondas do Geochip.

Ao estudar AOA, empregando PCR quantitativo para o gene amoA, Lammel (2011) encontrou maior abundância em solos de pastagem, comparando com floresta, na região amazônica. Diferenças entre as áreas de estudo, sistemas de amostragem (número de replicatas e profundidade do solo), metodologias empregadas e na forma de análise dos dados podem justificar a divergência entre os resultados do presente estudo e no estudo de Lammel. Em outro trabalho realizado na região, avaliando clones de gene amo $A$ de $A O A$, foi observado que comunidades de $A O A$ de pastagem se diferiam de florestas primária e secundária, e foi constatada maior riqueza em pastagem, porém maior diversidade em floresta (NAVARRETE et al., 2011).

Muitos estudos têm buscado compreender a importância de AOA e AOB em diferentes ambientes. AOA foi apontado recentemente como predominante em uma variedade de solos (LEININGER et al., 2006; WESSEN et al., 2011), mas a real contribuição desses dois grupos para a nitrificação ainda não está clara (ISOBE et al., 2011). Algumas evidências sugerem que $A O A$ seja o grupo de oxidadores de amônia predominante em solos com baixo $\mathrm{pH}$ e pobre em nutrientes, enquanto que AOB seria mais importante em ambientes mais ricos e com pH mais elevado (WESSEN et al., 2011). O dados do Geochip não permitem avaliar qual grupo é predominante nos solos da Amazônia, pois o emprego de sondas para sequências de genes já conhecidos pode favorecer o grupo mais bem estudado. Entretanto, as características do solo da Amazônia, como acidez e baixas concentrações de nutrientes (MULLER et al., 2004), levam à hipótese de que AOA seja o grupo predominante, como já foi sugerido previamente para solos ácidos de floresta (ISOBE et al., 2011). Além disso, a associação dos genes amoA de AOA às florestas 
corrobora esta hipótese, pois esses solos possuem menor $\mathrm{pH}$ e maior acidez potencial.

Uma série de trabalhos desenvolvidos na fazenda Nova Vida demonstraram que a taxa de nitrificação na floresta é maior, comparando com pastagem (NEILL et al., 1995; NEILL et al., 1997; CENCIANI, 2007). Entretanto, na floresta secundária a taxa de nitrificação também foi reduzida em relação à floresta primária (CENCIANI, 2007). Quanto às quantidades de $\mathrm{NO}_{3}{ }^{-}$e $\mathrm{NH}_{4}^{+}$, foram encontradas variações sazonais e diferenças entre estudos, mas em geral tende a haver um aumento de $\mathrm{NH}_{4}{ }^{+}$e redução de $\mathrm{NO}_{3}{ }^{-}$, ao converter a floresta para pastagem (NEILL et al., 1995; NEILL et al., 1997; CENCIANI, 2007). A menor concentração de $\mathrm{NH}_{4}{ }^{+}$nas florestas reforça a hipótese de que este ambiente favorece a colonização por AOA, pois a preferência por baixos teores de $\mathrm{NH}_{4}{ }^{+}$por este grupo de arqueias já foi descrita (WESSEN et al., 2011).

Oxidação anaeróbia de amônia (Anammox)

Anammox é a formação anaeróbica de $\mathrm{N}_{2}$ a partir de $\mathrm{NH}_{4}{ }^{+}$e $\mathrm{NO}_{2}^{-}$(STROUS; KUENEN; JETTEN, 1999). Este processo ainda é pouco compreendido, mas tem sido apontado como importante em diferentes ambientes (PENTON; DEVOL; TIEDJE, 2008).

Ao analisar o gene de uma enzima hidrazina oxidoredutase (hzo), responsável por converter 0 intermediário hidrazina em $N_{2}$, foi observada a associação dessa família de genes com as florestas e P99.

Desnitrificação e redução dissimilatória de nitrato

A desnitrificação é a redução anaeróbica de $\mathrm{NO}_{3}{ }^{-}$a $\mathrm{N}_{2}$, passando pelos intermediários $\mathrm{NO}_{2}^{-}, \mathrm{N}_{2} \mathrm{O}$ e NO (PHILIPPOT; HALLIN, 2005). É um importante passo do ciclo, devolvendo o nitrogênio para a atmosfera. No solo, juntamente com a nitrificação, consistem as principais fontes do gás $\mathrm{N}_{2} \mathrm{O}$ (BOLLMANN; CONRAD, 1998).

Dois genes que codificam para nitrato redutase, responsável pela redução de nitrato a nitrito foram avaliados: narG e napA. O primeiro, não demonstrou seletividade, associando-se a quatro diferentes sítios, enquanto que nap $A$, associou- 
se às florestas e P99. O gene da nitrito redutase (nfrA) responsável por reduzir nitrito a amônia, associou-se significativamente às florestas.

Dentre os genes restritos ao processo de desnitrificação, apenas norB (óxido nítrico redutase) apresentou certa preferência, associando-se às florestas e à pastagem P99. Os demais genes, nirk e nirS (nitrito redutase) e nosZ (óxido nitroso redutase), associaram-se a todos, menos $\mathrm{P} 6$, o que é provavelmente devido à uma associação negativa com este sítio.

Embora outros estudos tenham demonstrado diferenças entre os grupos que carregam nirk e nirS, quanto às suas respostas a alterações ambientais (ENWALL et al., 2010), o teste de associação mostrou resultados semelhantes para ambos, o que pode ser devido a uma falta de cobertura pelas sondas do Geochip ou simplesmente porque as mudanças na forma de uso do solo não causaram impactos detectáveis nessas comunidades.

Quantificações das emissões anuais de $\mathrm{N}_{2} \mathrm{O}$ e $\mathrm{NO}$ em solos submetidos a diferentes formas de uso na fazenda Nova Vida já foram realizadas (NEILL et al., 2005). Foi verificado que, logo após o desmatamento, a emissão de $\mathrm{N}_{2} \mathrm{O}$ é aumentada em pastagens de até 3 anos. Entretanto, com o aumento da idade da pastagem ocorre uma redução na emissão, atingindo níveis similares e inferiores aos encontrados nas florestas. Já a emissão de NO em todas pastagens é sempre menor que nas florestas. Comparando os perfis encontrados com características de porosidade e umidade do solo, bem como com dados de emissão seguindo adição de $\mathrm{NO}_{3}{ }^{-}$e $\mathrm{NH}_{4}{ }^{+}$, os autores apontaram a nitrificação, e não a desnitrificação, como principal fonte de $\mathrm{NO}$ e $\mathrm{N}_{2} \mathrm{O}$ nos solos de floresta. Não foi encontrada nenhuma ligação entre o resultados de genes de desnitrificação do presente trabalho e os dados de emissões de gases da fazenda Nova Vida. Por outro lado, a associação de genes de nitrificação às florestas estaria de acordo com o proposto por Neill et al. (2005), reforçando a hipótese de que micro-organismos nitrificantes seriam os principais responsáveis pela produção de $\mathrm{N}_{2} \mathrm{O}$ na floresta.

De forma semelhante, Lammel (2011) observou apenas uma pequena variação na abundância de genes ligados à desnitrificação em solos de pastagem e floresta na Amazônia. Entretanto, o autor verificou maior produção de $\mathrm{N}_{2} \mathrm{O}$ na floresta, e atribuiu a baixa produção na pastagem à menor concentração de $\mathrm{NO}_{3}{ }^{-}$e a uma possível inibição da nitrificação por gramíneas do gênero Brachiaria, como descrito por Subbarao et al. (2009). 


\section{Amonificação}

$\mathrm{Na}$ fazenda nova vida, já foi relatado que a taxa de mineralização de $\mathrm{N}$ em florestas é maior que em pastagens (NEILL et al., 1995; CENCIANI, 2007). Entretanto, verificamos que os genes ligados à amonificação, ureC (subunidade alfa da urease) e ghd (glutamato desidrogenase), não apresentaram preferencia seletiva no teste de associação a múltiplos sítios, apesar de terem maiores índices na floresta secundária no teste de sítios únicos.

Yergeau et al., (2007) empregando o Geochip, também relataram a falta de correlação entre os resultados desses genes e a taxa de mineralização. De acordo com os autores, isso pode estar relacionado com o fato de serem genes amplamente distribuídos nos grupos microbianos.

\section{Redução assimilatória de nitrato}

Genes relacionados à redução assimilatória de nitrato praticamente não sofreram impacto do uso do solo. Apenas a família nasA (nitrato redutase) apresentou resultado significativo no teste de associação, porém se associou a vários sítios, indicando ampla distribuição. Quanto aos genes de nitrito redutase (nirB e nirA), não houve associação significativa.

A não associação dessas famílias de genes a algum ambiente também pode estar relacionada com a ampla distribuição desta função por diferentes grupos microbianos (LUQUE-ALMAGRO et al., 2011).

\section{Fixação de Nitrogênio}

A fixação de $\mathrm{N}_{2}$ é um passo fundamental do ciclo, transformando forma inerte em forma disponível para utilização por plantas e micro-organismos. A disponibilidade de $\mathrm{N}$ influencia os processos de ciclagem, podendo caracterizar o ciclo como em estado de conservação ou de liberação de N (ERICKSON; KELLER; DAVIDSON, 2001).

O gene nifH codifica para a enzima nitrogenase redutase, que está presente em micro-organismos capazes de fixar nitrogênio, e é amplamente usado como marcador para estudar esse grupo microbiano (ZEHR et al., 2003). Esta família de 
genes se associou significativamente com as duas florestas, tendo a floresta secundária o maior índice de associação.

Recentemente, por meio de um levantamento de espécies de leguminosas e outras plantas simbiônticas, e quantificações de ${ }^{15} \mathrm{~N}$ na serapilheira, a fixação de nitrogênio foi apontada como importante para a recuperação de florestas secundárias na Amazônia, com potencial maior que a floresta primária (GEHRING et al., 2005). Erickson, Keller e Davidson (2001) também ressaltaram a importância do potencial para fixação de nitrogênio na recuperação de florestas tropicais, e correlacionou esse potencial com a emissão de óxidos de nitrogênio em floresta secundária.

As limitações existentes na quantificação deste processo (DAVIDSON et al., 2007) e a escassez de dados na região impedem que sejam feitas comparações entre o potencial genético e a capacidade metabólica.

\subsubsection{Ciclo do Carbono}

\section{Degradação de Carbono}

O tipo de cobertura vegetal e o manejo podem alterar a disponibilidade dos compostos de carbono, favorecendo a colonização por micro-organismos com vias metabólicas adequadas à condição oferecidas (ZHANG et al., 2007). O Geochip possui uma variedade de sondas para genes relacionados a degradação de diferentes compostos de carbono, e já foi empregado para detectar impacto do uso do solo sobre esses genes em outros ambientes (ZHANG et al., 2007; BERTHROG et al., 2009).

Famílias de genes relacionados com a degradação de amido, celulose, hemicelulose, lignina pectina e quitina foram testadas quanto à preferencia pelos solos. De 24 famílias testadas, 21 tiveram resultados significativos no teste de associação a múltiplos sítios, e 16 no teste de sítios únicos. Genes relacionados à degradação de amido se associaram a diferentes combinações de sítios, incluindo a pastagem P6 e as pastagens P6+P38, que não foram observadas em nenhum outro processo funcional. Com relação aos genes ligados à degradação dos demais compostos, não foram encontradas grandes diferenças entre eles, e no teste de associação a múltiplos sítios não apresentaram seletividade. Isso sugere que o uso 
do solo não causou grandes impactos na distribuição desses genes. Porém, o teste de sítios únicos indicou certo grau de preferencia.

Ensaios de degradação de substratos de carbono serão de grande importância para compreender esses processos nos solos da Amazônia, além de possibilitar a comparação com os dados de genes funcionais e então verificar se a abundância e distribuição dos genes podem ser utilizadas para prever a realização dos processos no solo.

\section{Fixação de Carbono}

A geração de biomassa no ecossistema depende diretamente de organismos autotróficos, ou seja, que utilizam $\mathrm{CO}_{2}$ como única fonte de carbono (ZARZYCKI et al., 2009). Além de converter carbono inorgânico em orgânico, disponibilizando para organismos heterotróficos, a fixação de carbono consome $\mathrm{CO}_{2}$ atmosférico, sendo portanto uma função importante relacionada a balanço de gases do efeito estufa.

Genes que codificam enzimas envolvidas em quatro das seis vias de fixação de carbono já descritas (SATO; ATOMI, 2010) foram avaliados. A enzima RibuloseBisfosfato Carboxilase (RuBisCo), encontrada em uma variedade de organismos autotróficos, possui papel chave na fixação de carbono via ciclo de Calvin-BensonBassham (BADGER; BEK, 2008). Foi verificada associação significativa da família de genes que codifica para esta enzima com as florestas primária e secundária, sendo que o maior índice correlação foi para a floresta secundária.

De forma semelhante, o gene FTHFS, que codifica para a enzima Formatotetrahidrofolato ligase, envolvida na via de redução Acetil-CoA (acetogênese), também se associou com as florestas, porém com maior índice na floresta primária. Apesar de acetogênese ser um processo anaeróbico, micro-organismos acetogênicos já foram isolados dos mais diferentes ambientes, incluindo solos bem drenados (DRAKE et al., 1997). Interessantemente, outro gene envolvido nesta mesma via, CODH (enzima monóxido de carbono desidrogenase), não apresentou semelhante seletividade.

Outras duas famílias de genes testadas também apresentaram uma ampla distribuição pelos sítios de amostragem: pcc (enzima propionil-CoA carboxilase, ciclo 3-Hidroxipropionato/4-hidroxibutirato) (ZARZYCKI et al., 2009); e ac/B (succinil-CoA sintetase ciclo dicarboxilato/hidroxibutirato) (HUBER et al., 2008). 
Produção e consumo de metano

Foram avaliados genes relacionados tanto à produção, quanto ao consumo de metano. A família de genes $m c r A$, codifica para a subunidade alfa da metil coenzima $M$ redutase, enzima chave no processo de produção de metano (LUTON et al., 2002). Não houve associação significativa dessa família de genes com nenhum sítio de amostragem, indicando uma ampla distribuição entre os ambientes.

Com relação à oxidação do metano, foram analisados dois genes que codificam para a subunidade alfa da metano mono-oxigenase: $p m o A$ (forma particulada da enzima) e mmoX (forma solúvel) (HORZ; YIMGA; LIESACK, 2001). Enquanto que $m m o X$ não apresentou seletividade por sítios de amostragem, $p m o A$ se associou significativamente às florestas, sendo o maior índice de correlação obtido para a floresta secundária.

Estes resultados diferem-se do observado em outra área da região amazônica, onde foi verificada maior abundância de mcrA na floresta e abundâncias semelhantes de pmoA em floresta e pastagem (Lammel, 2011). Entretanto no mesmo trabalho o autor observou maior fluxo de metano em pastagem.

$\mathrm{Na}$ fazenda Nova Vida, a conversão de floresta para pastagem é geralmente acompanhada de uma mudança no fluxo anual de metano no solo, o qual deixa de agir como sumidouro, passando a ser fonte deste gás (STEUDLER et al., 1996; FERNANDES et al., 2002). Segundo Steudler et al. (1996) a utilização da área como pastagem promove a compactação do solo, o que reduz a porosidade e dificulta a difusão de oxigênio, favorecendo o metabolismo metanogênico. Já os solos de florestas, caracterizados por menor retenção de umidade e maior porosidade, favorecem a difusão de metano, o que propicia a atividade de micro-organismos metanotróficos.

Levine et al. (2011) demonstraram correlação positiva entre o consumo de metano e a riqueza de genes pmoA. A associação dessa família de genes aos solos de florestas indica que comunidades de metanotróficas possuem preferência por este ambiente, o que poderia explicar o maior consumo de $\mathrm{CH}_{4}$, demonstrado anteriormente em ensaios de fluxo de gás. Além disso, os resultados sugerem uma restauração do potencial genético ligado a esta função na floresta secundária. 


\subsection{Acesso ao potencial funcional do solo da Amazônia empregando Geochip}

Com o emprego do Geochip foi possível acessar a diversidade de genes funcionais em solos da Amazônia, bem como verificar o impacto do uso do solo sobre diferentes aspectos: riqueza, diversidade, estrutura e distribuição dos genes. Tamanha variedade de enfoques abordados só foi possível devido à complexidade e à riqueza de dados obtidos. Além de revelar o perfil do genoma funcional das comunidades do solo frente à pressão ambiental, os dados obtidos podem ser usados como uma pré-triagem, funcionando como guia para futuros estudos onde genes de interesse serão selecionados para uma análise aprofundada.

Por outro lado, é necessário lembrar que o Geochip avalia apenas sequências de genes já conhecidas e que já foram depositadas no banco de dados. Um ambiente pouco estudado, como é o solo da Amazônia, pode ter sua diversidade subestimada, devido à falta de cobertura de seus genes. Entretanto a técnica se mostrou eficaz para detectar diferenças dentro deste ecossistema. Trabalhos de sequenciamento na área serão de grande importância para enriquecer os bancos de dados com sequências de genes provenientes da Amazônia.

Com relação ao teste de associação de genes, este foi considerado uma ferramenta útil para a análise dos dados, permitindo explorá-los mais detalhadamente e apresentar resultados complexos de forma sintética. $O$ fato de diferentes perfis terem sido observados para as famílias de genes, indica que tanto o Geochip, quanto o teste de associação, possuem sensibilidade para detectar os padrões de respostas dos grupos funcionais que se comportam de diferentes formas diante de perturbações ambientais. Finalmente, a concordância dos resultados de associação de alguns genes (principalmente genes exclusivos de grupos microbianos especializados) com os dados disponíveis na literatura sobre processos microbianos na região, apontam este índice como um possível método para selecionar genes funcionais ligados a processos importantes, e que respondam a alterações ambientais. Esses genes podem ser empregados como bio-indicadores em trabalhos de monitoramento ambiental, como sugerido por Wessen e Hallin (2011). A coleta de dados de processos relacionados a esses genes juntamente com as amostras utilizadas para a análise de DNA pode enriquecer a análise, e possibilitar comparações mais diretas entre comunidade e função. Entretanto, avaliações pontuais desses processos estão sujeitas a oscilações. Isso ocorre pois 
micro-organismos podem responder rapidamente a mudanças ambientais, sem necessariamente sofrer grandes alterações na composição da comunidade (ALLISON; MARTINY, 2008). Por esse motivo, a maioria dos dados de metabolismo utilizados aqui são referentes a médias anuais ou tiveram concordância em diferentes estudos. De forma semelhante, análises de RNA mensageiro podem revelar os grupos que estão ativos no solo, porém a sensibilidade de processos transcricionais a oscilações ambientais requerem maiores esforços de amostragem para que conclusões robustas possam ser feitas.

\subsection{Impacto do uso do solo sobre o potencial funcional em solos da Amazônia}

Os resultados obtidos neste trabalho indicam que a estrutura da comunidade funcional do solo da Amazônia se altera, seguindo o estabelecimento de pastagens, e tende a ser recuperada com o crescimento da floresta secundária, de maneira similar ao observado para a estrutura taxonômica, em trabalhos anteriores (JESUS et al., 2009). A estrutura funcional da comunidade sofreu influência de fatores ambientais, dando suporte à hipótese de que as mudanças ocorrem no sentido de favorecer genomas funcionais adaptados às condições disponíveis. Entretanto ao contrário da diversidade taxonômica, houve uma redução da diversidade funcional nas pastagens, indicando impacto sobre o potencial funcional.

A observação de alteração no genoma funcional concorda com trabalhos anteriores que, por meio de análises de processos, indicaram que o uso do solo para pastagem promove a alteração da comunidade a nível funcional.

A inclusão da pastagem P99 nas análises foi considerada importante para demonstrar que características e tipo de solo possuem grande influencia sobre aspectos da comunidade microbiana, como estrutura e riqueza de genes funcionais. A não consideração desses fatores na análise poderia conduzir a conclusões erradas com relação à pastagem mais velha, como a restauração da comunidade similar à floresta após um longo tempo de uso do solo.

A floresta secundária é considerada uma alternativa para a recuperação do ecossistema e manutenção da biodiversidade. O restabelecimento das funções microbianas encontradas na floresta primária reforça a importância desse ambiente na restauração de locais que sofreram desmatamento e foram empregados como pastagem. Davidson et al. (2007) demonstraram a recuperação gradual de funções 
relacionadas ao ciclo do nitrogênio em florestas secundárias de 3 a 70 anos. De acordo com os autores, o tempo de recuperação dos processos metabólicos pode refletir a cinética de mobilização de $\mathrm{N}$ recalcitrante no solo para o ciclo ativo, e o grau de degradação adquirido pelo solo durante seu uso como pastagem, tendo importância o tempo de uso, a forma de manejo e o número de ciclos de aplicação de fogo. Os dados de riqueza, estrutura e de associação de genes mostram que a recuperação do potencial genético ligado a esses e outros processos estão se restabelecendo em uma floresta secundária recente (apenas 13 anos).

Existe uma dificuldade em prever recuperações significativas para 0 ecossistema amazônico baseando-se em florestas secundárias, pois com frequência estas são derrubadas novamente (DAVIDSON et al., 2012). Diante da extensa área já desmatada na Amazônia, o desenvolvimento de políticas públicas que incentivem a recuperação e a conservação de áreas de florestas secundárias pode ajudar a restabelecer funções importantes para a manutenção do ecossistema. 


\section{CONCLUSÕES}

1) Os solos da Amazônia analisados apresentam uma grande diversidade de genes funcionais relacionados a diferentes processos, incluindo ciclos biogeoquímicos, degradação de compostos orgânicos, resistência a antibióticos, resistência a metais, estresse, virulência e processos energéticos.

2) O desmatamento da floresta nativa seguido pela formação de pastagem para pecuária causou na área estudada uma redução da riqueza e diversidade de genes funcionais ligados a processos microbianos no solo, diferentemente ao observado para a diversidade taxonômica. Esta perda da diversidade sugere uma redução do potencial genético funcional nas pastagens.

3) A conversão de floresta nativa a pastagem pode ocasionar impacto sobre a estrutura funcional da comunidade microbiana do solo, semelhante ao relatado para a estrutura taxonômica. Portanto a comunidade da pastagem não é funcionalmente redundante à da floresta.

4) A floresta secundária apresentou diversidade e estrutura funcional da comunidade semelhantes à floresta primária, o que indica que o potencial genético funcional, alterado durante o uso do solo para pastagem, pode estar sendo recuperado neste ambiente.

5) Algumas características físico-químicas do solo ( $C, N, M O, A l, H+A, B$ e $P$ ) tiveram influência sobre a estrutura funcional da comunidade e podem estar relacionadas com as diferenças encontradas entre os sítios de amostragem.

6) Características inerentes ao tipo de solo possuem grande influência sobre a comunidade microbiana e podem guiar respostas diferenciadas, como ocorreu com a pastagem de 99 anos. Esta apresentou alta diversidade e estrutura semelhante às florestas. O tipo de solo deve ser levado em consideração ao comparar comunidades, para evitar conclusões erradas quanto aos efeitos do uso do solo. 
7) Nos solos analisados, não foi encontrado um padrão de distribuição espacial de genes funcionais. Entretanto, este parâmetro precisa ser melhor avaliado em maior escala espacial e com um maior número de amostras.

8) A aplicação do índice de associação para genes foi considerada uma ferramenta eficaz para buscar por grupos funcionais que respondam a impactos ambientais e que possam funcionar como bioindicadores. Com este índice foi possível verificar:

a. Um impacto do uso do solo sobre a presença e abundância de algumas famílias genes funcionais.

b. Os sítios com maior número de famílias de genes associadas foram as florestas primária e secundária, sugerindo maior potencial genético funcional desses ambientes. Além disso a associação de genes à combinação das florestas indica a semelhança entre estes sítios, o que reforça a hipótese de recuperação do potencial funcional na floresta secundária.

c. Existem diferenças nas respostas entre grupos funcionais.

d. Os resultados de algumas famílias de genes concordaram com dados de processos funcionais disponíveis na literatura, o que indica que o índice de associação pode ser considerado uma ferramenta útil para prever o potencial funcional. 


\section{REFERÊNCIAS*}

ALLISON, S. D.; MARTINY, J. B. H. Resistance, resilience, and redundancy in microbial communities. Proceedings of the National Academy of Sciences of the United States of America, v. 105, p. 11512-11519, 2008.

ATLAS, R. M. Principles of Microbiology. 2 ed. Dubuque: WCB, 1997, 1298 p.

BADGER, M. R.; BEK, E. J. Multiple Rubisco forms in proteobacteria: their functional significance in relation to $\mathrm{CO}(2)$ acquisition by the $\mathrm{CBB}$ cycle. Journal of Experimental Botany, v. 59, n. 7, p. 1525-1541, 2008.

BAKKER, J. D. Increasing the utility of Indicator Species Analysis. Journal of Applied Ecology, v. 45, n. 6, p. 1829-1835, 2008.

BARRETO, P. et al. Pressão humana na floresta Amazônica brasileira. Belém: Imazon, 2005, $84 \mathrm{p}$.

BASTOS, T. X.; DINIZ, T. D. A. S. Avaliação do clima do Estado de Rondônia para desenvolvimento agrícola. Boletim de Pesquisa, n. 44, p. 187-197, 2004.

BENJAMINI, Y.; HOCHERG, Y. Controlling the false discovery rate: a practical and powerful approach to multiple testing. Journal of the Royal Statistical Society: Series B, v. 57, 289-300, 1995.

BERTHRONG, S. T. et al. Afforestation alters the composition of functional genes in soil and biogeochemical processes in South American Grasslands. Applied and Environmental Microbiology, v. 75, n. 19, p. 6240-6248, 2009.

BODROSSY, L. et al. Development and validation of a diagnostic microbial microarray for methanotrophs. Environmental Microbiology, v. 5, n. 7, p. 566-582, 2003.

BOLLMANN, A.; CONRAD, R. Influence of $\mathrm{O}(2)$ availability on $\mathrm{NO}$ and $\mathrm{N}(2) \mathrm{O}$ release by nitrification and denitrification in soils. Global Change Biology, v. 4, n. 4, p. 387396, 1998.

BORNEMAN, J.; TRIPLETT, E. W. Molecular microbial diversity in soils from eastern Amazonia: Evidence for unusual microorganisms and microbial population shifts associated with deforestation. Applied and Environmental Microbiology, v. 63, n. 7, p. 2647-2653, 1997.

BOTTARI, B. et al. Application of FISH technology for microbiological analysis: current state and prospects. Applied Microbiology and Biotechnology, v. 73, n. 3, p. 485-494, 2006.

CALL, D. R. et al. Identifying antimicrobial resistance genes with DNA microarrays. Antimicrobial Agents and Chemotherapy, v. 47, n. 10, p. 3290-3295, 2003.

*De acordo com:

ASSOCIAÇÃO BRASILEIRA DE NORMAS TÉCNICAS. NBR 6023: Informação e documentação: referências: elaboração. Rio de Janeiro, 2002. 
CAMARGO, O. A. et al. Métodos de análise química, mineralógica e física de solos do Instituto Agronômico de Campinas. Campinas: Instituto Agronômico, 1986, 94 p.

CENCIANI, K. Diversidade bacteriana em solos da Amazônia: variabilidade dos gêneros associados ao processo de nitrificação. 2007. 103 f. Tese (Doutorado em Agronomia) - Escola Superior de Agricultura Luiz de Queiroz, Universidade de São Paulo, Piracicaba, 2007.

CENCIANI, K. et al. Bacteria diversity and microbial biomass in forest, pasture and fallow soils in the Southwestern Amazon Basin. Revista brasileira de ciencia do solo, v. 33, n. 4, p. 907-916, 2009.

CHAPIN, F. S. et al. Consequences of changing biodiversity. Nature, v. 405, n. 6783, p. 234-242, 2000.

CLARKE, K. R. Nonparametric multivariate analyses of changes in community structure. Australian Journal of Ecology, v. 18, n. 1, p. 117-143, 1993.

COLEMAN, D. C.; WHITMAN, W. B. Linking species richness, biodiversity and ecosystem function in soil systems. Pedobiologia, v. 49, n. 6, p. 479-497, 2005.

DA SILVA, J. M. C.; RYLANDS, A. B.; DA FONSECA, G. A. B. The fate of the Amazonian areas of endemism. Conservation Biology, v. 19, n. 3, p. 689-694, 2005.

DAVIDSON, E. A. et al. The Amazon basin in transition. Nature, v. 481, n. 7381, p. 321-328, 2012.

DAVIDSON, E. A. et al. Recuperation of nitrogen cycling in Amazonian forests following agricultural abandonment. Nature, v. 447, n. 7147, p. 995-998, 2007.

DE CACERES, M.; LEGENDRE, P. Associations between species and groups of sites: indices and statistical inference. Ecology, v. 90, n. 12, p. 3566-3574, 2009.

DE CACERES, M.; LEGENDRE, P.; MORETTI, M. Improving indicator species analysis by combining groups of sites. Oikos, v. 119, n. 10, p. 1674-1684, 2010.

DE MORAES, J. F. L. et al. Soil properties under Amazon forest and changes due to pasture installation in Rondonia, Brazil. Geoderma, v. 70, n. 1, p. 63-81, 1996.

DENG, Y. et al. Design and analysis of mismatch probes for long oligonucleotide microarrays. Bmc Genomics, v. 9, p. 491-594, 2008.

DING, Q. et al. Diversity and composition of ectomycorrhizal community on seedling roots: the role of host preference and soil origin. Mycorrhiza, v. 21, n. 8, p. 669-680, 2012.

DO CARMO, J. B. et al. A source of methane from upland forests in the Brazilian Amazon. Geophysical Research Letters, v. 33, n. 4, 2006. 
DRAKE, H. L. et al. Acetogenic bacteria: what are the in situ consequences of their diverse metabolic versatilities? Biofactors, v. 6, n. 1, p. 13-24, 1997.

DUFRENE, M.; LEGENDRE, P. Species assemblages and indicator species: The need for a flexible asymmetrical approach. Ecological Monographs, v. 67, n. 3, p. 345-366, 1997.

EDDY, S. R. Profile hidden Markov models. Bioinformatics, v. 14, n. 9, p. 755-763, 1998.

ENWALL, K. et al. Soil Resources Influence Spatial Patterns of Denitrifying Communities at Scales Compatible with Land Management. Applied and Environmental Microbiology, v. 76, n. 7, p. 2243-2250, 2010.

ERICKSON, H.; KELLER, M.; DAVIDSON, E. A. Nitrogen oxide fluxes and nitrogen cycling during postagricultural succession and forest fertilization in the humid tropics. Ecosystems, v. 4, n. 1, p. 67-84, 2001.

FEARNSIDE, P. M. Biodiversity as an environmental service in Brazil's Amazonian forests: risks, value and conservation. Environmental Conservation, v. 26, n. 4, p. 305-321, 1999.

FEARNSIDE, P.M. Desmatamento na Amazônia brasileira: história, indices e consequências. Megadiversidade, v. 1, n. 1, p. 113-123, 2005.

FEIGL, B. J.; CERRI, C. C.; BERNOUX, M. Balanço de carbono e biomassa microbiana em solos da Amazônia. In: MELO, I. S.; AZEVEDO, J. L. (Ed.). Ecologia Microbiana. Jaguariúna: Embrapa-CNPMA, 1998, p.423-441.

FERNANDES, S. A. P. et al. Seasonal variation of soil chemical properties and CO2 and $\mathrm{CH} 4$ fluxes in unfertilized and P-fertilized pastures in an ultisol of the Brazilian Amazon. Geoderma, v. 107, n. 3-4, p. 227-241, 2002.

FIERER, N.; JACKSON, R. B. The diversity and biogeography of soil bacterial communities. Proceedings of the National Academy of Sciences of the United States of America, v. 103, n. 3, p. 626-631, 2006.

FITTER, A. H. et al. Biodiversity and ecosystem function in soil. Functional Ecology, v. 19, n. 3, p. 369-377, 2005.

GABRIEL, J. Development of soil microbiology methods: from respirometry to molecular approaches. Journal of Industrial Microbiology \& Biotechnology, v. 37, n. 12, p. 1289-1297, 2010.

GALFORD, G. L. et al. Historical carbon emissions and uptake from the agricultural frontier of the Brazilian Amazon. Ecological Applications, v. 21, n. 3, p. 750-763, 2011. 
GEHRING, C. et al. Biological nitrogen fixation in secondary regrowth and mature rainforest of central Amazonia. Agriculture Ecosystems \& Environment, v. 111, n. 1-4, p. 237-252, 2005.

GREEN, J.; BOHANNAN, B. J. M. Spatial scaling of microbial biodiversity. Trends in Ecology \& Evolution, v. 21, n. 9, p. 501-507, 2006.

GREEN, J. L.; BOHANNAN, B. J. M.; WHITAKER, R. J. Microbial biogeography: From taxonomy to traits. Science, v. 320, n. 5879, p. 1039-1043, 2008.

GUSCHIN, D. Y. et al. Oligonucleotide microchips as genosensors for determinative and environmental studies in microbiology. Applied and Environmental Microbiology, v. 63, n. 6, p. 2397-2402, 1997.

HALLIN, S. et al. Relationship between $\mathrm{N}$-cycling communities and ecosystem functioning in a 50-year-old fertilization experiment. Isme Journal, v. 3, n. 5, p. 597605, 2009.

HANSEL, C. M. et al. Changes in bacterial and archaeal community structure and functional diversity along a geochemically variable soil profile. Applied and Environmental Microbiology, v. 74, n. 5, p. 1620-1633, 2008.

HARMS, K. E. et al. Habitat associations of trees and shrubs in a 50-ha neotropical forest plot. Journal of Ecology, v. 89, n. 6, p. 947-959, 2001.

HE, X. Y. et al. Land reclamation and short-term cultivation change soil microbial communities and bacterial metabolic profiles. Society of Chemical Industry, v. 92, n. 5, p.1103-1111, 2012.

HE, Z. et al. GeoChip: a comprehensive microarray for investigating biogeochemical, ecological and environmental processes. Isme Journal, v. 1, n. 1, p. 67-77, 2007.

HE, Z. et al. Development and application of functional gene arrays for microbial community analysis. Transactions of Nonferrous Metals Society of China, v. 18, n. 6, p. 1319-1327, 2008.

$\mathrm{HE}$, Z. et al. GeoChip 3.0 as a high-throughput tool for analyzing microbial community composition, structure and functional activity. Isme Journal, v. 4, n. 9, p. 1167-1179, 2010a.

$\mathrm{HE}, \mathrm{Z}$. et al. Metagenomic analysis reveals a marked divergence in the structure of belowground microbial communities at elevated $\mathrm{CO}(2)$. Ecology Letters, v. 13, n. 5, p. 564-575, 2010b.

HE, Z. et al. Development and applications of functional gene microarrays in the analysis of the functional diversity, composition, and structure of microbial communities. Frontiers of Environmental Science \& Engineering in China, v. 5, n. 1, p. 1-20, 2011. 
HERPIN, U. et al. Biogeochemical dynamics following land use change from forest to pasture in a humid tropical area (Rondonia, Brazil): a multi-element approach by means of XRF-spectroscopy. Science of the Total Environment, v. 286, n. 1-3, p. 97-109, 2002.

HORNER-DEVINE, M. C.; CARNEY, K. M.; BOHANNAN, B. J. M. An ecological perspective on bacterial biodiversity. Proceedings of the Royal Society of London Series B-Biological Sciences, v. 271, n. 1535, p. 113-122, 2004.

HORZ, H. P.; YIMGA, M. T.; LIESACK, W. Detection of methanotroph diversity on roots of submerged rice plants by molecular retrieval of pmoA, mmoX, mxaF, and 16S rRNA and ribosomal DNA, including pmoA-based terminal restriction fragment length polymorphism profiling. Applied and Environmental Microbiology, v. 67, n. 9, p. 4177-4185, 2001.

HUBER, H. et al. A dicarboxylate/4-hydroxybutyrate autotrophic carbon assimilation cycle in the hyperthermophilic Archaeum Ignicoccus hospitalis. Proceedings of the National Academy of Sciences of the United States of America, v. 105, n. 22, p. 7851-7856, 2008.

ISOBE, K. et al. Nitrification and nitrifying microbial communities in forest soils. Journal of Forest Research, v. 16, n. 5, p. 351-362, 2011.

JACOMINE, P. K. T. A nova versão do sistema brasileiro de classificação de solos (SiBCS). Recife: EMBRAPA, 2006. Disponível em: http://www.cnps.embrapa.br/sibcs/download/ata10.pdf. Acesso em: 10 Jan. 2012.

JESUS, E. D. C. et al. Changes in land use alter the structure of bacterial communities in Western Amazon soils. Isme Journal, v. 3, n. 9, p. 1004-1011, 2009.

KAUFFMAN, J. B.; CUMMINGS, D. L.; WARD, D. E. Fire in the Brazilian Amazon 2. Biomass, nutrient pools and losses in cattle pastures. Oecologia, v. 113, n. 3, p. 415-427, 1998.

KIM, J.-S. et al. Bacterial diversity of terra preta and pristine forest soil from the Western Amazon. Soil Biology \& Biochemistry, v. 39, n. 2, p. 684-690, 2007.

KIMES, N. E. et al. Microbial functional structure of Montastraea faveolata, an important Caribbean reef-building coral, differs between healthy and yellow-band diseased colonies. Environmental Microbiology, v. 12, n. 2, p. 541-556, 2010.

KINDT, R.; COE, R. Tree diversity analysis: a manual and software for common statistical methods for ecological and biodiversity studies. Nairobi: World Agroforestry Centre, 2005, $196 \mathrm{p}$.

KURAMAE, E. et al. Soil and plant factors driving the community of soil-borne microorganisms across chronosequences of secondary succession of chalk grasslands with a neutral pH. Fems Microbiology Ecology, v. 77, n. 2, p. 285-294, 2011. 
KURAMAE, E. E. et al. Soil characteristics more strongly influence soil bacterial communities than land-use type. Fems Microbiology Ecology, v. 79, n. 1, p. 12-24, 2012.

KRUSCHE, A. V. et al. Efeitos das mudanças do uso da tera na biogeoquímica dos corpos d'água da bacia do rio Ji-Paraná, Rondônia. Acta Amazônica. v. 35, n. 2, p. 197-205, 2005.

LAMMEL, D. R. Soil microbiota related to carbon, nitrogen and greenhouse gas cycles across different land uses in Southwestern Amazonia. 2011. $151 \mathrm{f}$. Tese (Doutorado em Ciências) - Centro de Energia Nuclear na Agricultura, Universidade de São Paulo, São Paulo, 2011.

LARSEN, F. W.; BLADT, J.; RAHBEK, C. Improving the performance of indicator groups for the identification of important areas for species conservation. Conservation Biology, v. 21, n. 3, p. 731-740, 2007.

LEGENDRE, P; LEGENDRE, L. Numerical ecology. 2 ed. Amsterdam: Elsevier Science BV, 1998, $853 \mathrm{p}$.

LEININGER, S. et al. Archaea predominate among ammonia-oxidizing prokaryotes in soils. Nature, v. 442, n. 7104, p. 806-809, 2006.

LEVINE, U. Y. et al. Agriculture's impact on microbial diversity and associated fluxes of carbon dioxide and methane. Isme Journal, v. 5, n. 10, p. 1683-1691, 2011.

LI, X. Y.; HE, Z. L.; ZHOU, J. Z. Selection of optimal oligonucleotide probes for microarrays using multiple criteria, global alignment and parameter estimation. Nucleic Acids Research, v. 33, n. 19, p. 6114-6123, 2005.

LIANG, Y. et al. Microarray-based analysis of microbial functional diversity along an oil contamination gradient in oil field. Fems Microbiology Ecology, v. 70, n. 2, p. 324-333, 2009.

LIEBICH, J. et al. Improvement of oligonucleotide probe design criteria for functional gene microarrays in environmental applications. Applied and Environmental Microbiology, v. 72, n. 2, p. 1688-1691, 2006.

LUQUE-ALMAGRO, V. M. et al. Bacterial nitrate assimilation: gene distribution and regulation. Biochemical Society Transactions, v. 39, p. 1838-1843, 2011.

LUTON, E. P. et al. The mcrA gene as an alternative to $16 \mathrm{~S}$ rRNA in the phylogenetic analysis of methanogen populations in landfill. Microbiology, v. 148, p. 3521-3530, 2002.

MADSEN, E. L. Environmental microbiology: from genomes to biogeochemistry. Malden: Backwell Publishing, 2008, 479 p.

MAGURRAN, A.E. Measuring biological diversity. Oxford: Blackwell, 2004, 256 p. 
MORALES, S. E.; COSART, T.; HOLBEN, W. E. Bacterial gene abundances as indicators of greenhouse gas emission in soils. Isme Journal, v. 4, n. 6, p. 799-808, 2010.

MULLER, M. M. L. et al. The relationship between pasture degradation and soil properties in the Brazilian amazon: a case study. Agriculture Ecosystems \& Environment, v. 103, n. 2, p. 279-288, 2004.

NAVARRETE, A. A. et al. Land-use systems affect Archaeal community structure and functional diversity in Western Amazon soils. Revista Brasileira de Ciencia do Solo, v. 35, n. 5, p. 1527-1540, 2011.

NEILL, C. et al. Soil carbon and nitrogen stocks following forest clearing for pasture in the southwestern Brazilian Amazon. Ecological Applications, v. 7, n. 4, p. 1216$1225,1997$.

NEILL, C. et al. Nitrogen dynamics in soils of forest and active pastures in Western Brazilian Amazon Basin. Soil Biology \& Biochemistry, v. 27, n. 9, p. 1167-1175, 1995.

NEILL, C. et al. Rates and controls of nitrous oxide and nitric oxide emissions following conversion of forest to pasture in Rondonia. Nutrient Cycling in Agroecosystems, v. 71, n. 1, p. 1-15, 2005.

OKSANEN, J. et al. Vegan: community ecology. R Package version 1.17-11, 2011. Disponível em: Htpp://CRAN.R-project.org/package=vegan.

PALM, C. A. et al. Nitrous oxide and methane fluxes in six different land use systems in the Peruvian Amazon. Global Biogeochemical Cycles, v. 16, n. 4, 2002.

PENTON, C. R.; DEVOL, A. H.; TIEDJE, J. M. Molecular evidence for the broad distribution of anaerobic ammonium-oxidizing bacteria in freshwater and marine sediments. Applied and Environmental Microbiology, v. 72, n. 10, p. 6829-6832, 2006.

PHILIPPOT, L.; HALLIN, S. Finding the missing link between diversity and activity using denitrifying bacteria as a model functional community. Current Opinion in Microbiology, v. 8, n. 3, p. 234-239, 2005.

R DEVELOPMENT CORE TEAM. R: A Language and environment for statistical computing. Vienna: R Foundation for statistical computing, 2010, ISBN: 3-90005107-0. Disponível em: http://www.R-project.org.

REEVE, J. R. et al. Effects of soil type and farm management on soil ecological functional genes and microbial activities. Isme Journal, v. 4, n. 9, p. 1099-1107, 2010.

RHEE, S. K. et al. Detection of genes involved in biodegradation and biotransformation in microbial communities by using 50 -mer oligonucleotide 
microarrays. Applied and Environmental Microbiology, v. 70, n. 7, p. 4303-4317, 2004.

ROESCH, L. F. et al. Pyrosequencing enumerates and contrasts soil microbial diversity. Isme Journal, v. 1, n. 4, p. 283-290, 2007.

SALA, O. E. et al. Biodiversity - Global biodiversity scenarios for the year 2100 . Science, v. 287, n. 5459, p. 1770-1774, 2000.

SATO, T.; ATOMI, H. Microbial inorganic carbon fixation. In: Encyclopedia of life science. Chichester: John Wiley \& Sons Ltd., 2010, [12 p].

SINGER, V. L. et al. Characterization of PicoGreen reagent and development of a fluorescence-based solution assay for double-stranded DNA quantitation. Analytical Biochemistry, v. 249, n. 2, p. 228-238, 1997.

STEUDLER, P. A. et al. Consequence of forest-to-pasture conversion on $\mathrm{CH} 4$ fluxes in the Brazilian Amazon Basin. Journal of Geophysical Research-Atmospheres, v. 101, n. D13, p. 18547-18554, 1996.

STROUS, M.; KUENEN, J. G.; JETTEN, M. S. M. Key physiology of anaerobic ammonium oxidation. Applied and Environmental Microbiology, v. 65, n. 7, p. 3248-3250, 1999.

SUBBARAO, G. V. et al. Evidence for biological nitrification inhibition in Brachiaria pastures. Proceedings of the National Academy of Sciences of the USA, v. 106, n. 41, p. 17302-17307, 2009.

SWIFT, M. J. et al. Global change, soil biodiversity, and nitrogen cycling in terrestrial ecosystems: three case studies. Global Change Biology, v. 4, n. 7, p. 729-743, 1998.

TAKETANI, R. G.; TSAI, S. M. The Influence of Different Land Uses on the Structure of Archaeal Communities in Amazonian Anthrosols Based on 16S rRNA and amoA Genes. Microbial Ecology, v. 59, n. 4, p. 734-743, 2010.

TARONCHER-OLDENBURG, G. et al. Oligonucleotide microarray for the study of functional gene diversity in the nitrogen cycle in the environment. Applied and Environmental Microbiology, v. 69, n. 2, p. 1159-1171, 2003.

THIES, J. E. Soil microbial community analysis using terminal restriction fragment length polymorphisms. Soil Science Society of America Journal, v. 71, n. 2, p. 579-591, 2007.

TIQUIA, S. M. et al. Evaluation of 50-mer oligonucleotide arrays for detecting microbial populations in environmental samples. Biotechniques, v. 36, n. 4, p. 664675, 2004.

TORSVIK, V.; OVREAS, L. Microbial diversity and function in soil: from genes to ecosystems. Current Opinion in Microbiology, v. 5, n. 3, p. 240-245, 2002.VAN 
ELSAS, J. D. et al. Microbial diversity determines the invasion of soil by a bacterial pathogen. Proceedings of the National Academy of Sciences of the United States of America, v. 109, n. 4, p. 1159-1164, 2012.

VAN NOSTRAND, J. D. et al. GeoChip-based analysis of functional microbial communities during the reoxidation of a bioreduced uranium-contaminated aquifer. Environmental Microbiology, v. 11, n. 10, p. 2611-2626, 2009.

VAN RAIJ, B et al. Análise química para avaliação da fertilidade de solos tropicais. Campinas: Instituto Agronômico, 2001, 284 p.

VERCHOT, L. V. et al. Land-use change and biogeochemical controls of methane fluxes in soils of eastern Amazonia. Ecosystems, v. 3, n. 1, p. 41-56, 2000.

VIEIRA, I. C. G.; SILVA, J. M. C.; TOLEDO, P. M. Estratégias para evitar a perda de biodiversidade na Amazônia. Estudos Avançados, v. 19, n. 54, p. 153-164, 2005.

WAKELIN, S. A. et al. Habitat selective factors influencing the structural composition and functional capacity of microbial communities in agricultural soils. Soil Biology \& Biochemistry, v. 40, n. 3, p. 803-813, 2008.

WALDRON, P. J. et al. Functional gene array-based analysis of microbial community structure in groundwaters with a gradient of contaminant levels. Environmental Science \& Technology, v. 43, n. 10, p. 3529-3534, 2009.

WANG, F. et al. GeoChip-based analysis of metabolic diversity of microbial communities at the Juan de Fuca Ridge hydrothermal vent. Proceedings of the National Academy of Sciences of the United States of America, v. 106, n. 12, p. 4840-4845, 2009.

WEISS, J. M.; REICE, S. R. The aggregation of impacts: Using species-specific effects to infer community-level disturbances. Ecological Applications, v. 15, n. 2, p. 599-617, 2005.

WESSEN, E.; HALLIN, S. Abundance of archaeal and bacterial ammonia oxidizers Possible bioindicator for soil monitoring. Ecological Indicators, v. 11, n. 6, p. 16961698, 2011.

WESSEN, E. et al. Spatial distribution of ammonia-oxidizing bacteria and archaea across a 44-hectare farm related to ecosystem functioning. Isme Journal, v. 5, n. 7, p. 1213-1225, 2011.

WU, L. et al. Microarray-based characterization of microbial community functional structure and heterogeneity in marine sediments from the gulf of Mexico. Applied and Environmental Microbiology, v. 74, n. 14, p. 4516-4529, 2008.

WU, L. et al. Microarray-based analysis of subnanogram quantities of microbial community DNAs by using whole-community genome amplification. Applied and Environmental Microbiology, v. 72, n. 7, p. 4931-4941, 2006. 
WU, L. Y. et al. Development and evaluation of functional gene arrays for detection of selected genes in the environment. Applied and Environmental Microbiology, v. 67, n. 12, p. 5780-5790, 2001.

WU, L. Y. et al. Development and evaluation of microarray-based whole-genome hybridization for detection of microorganisms within the context of environmental applications. Environmental Science \& Technology, v. 38, n. 24, p. 6775-6782, 2004.

XIONG, J. et al. Microbial Communities and Functional Genes Associated with Soil Arsenic Contamination and the Rhizosphere of the Arsenic-Hyperaccumulating Plant Pteris vittata L. Applied and Environmental Microbiology, v. 76, n. 21, p. 72777284, 2010.

YERGEAU, E. et al. Functional microarray analysis of nitrogen and carbon cycling genes across an Antarctic latitudinal transect. Isme Journal, v. 1, n. 2, p. 163-179, 2007.

YIN, B. et al. Bacterial functional redundancy along a soil reclamation gradient. Applied and Environmental Microbiology, v. 66, n. 10, p. 4361-4365, 2000.

ZARZYCKI, J. et al. Identifying the missing steps of the autotrophic 3hydroxypropionate $\mathrm{CO}(2)$ fixation cycle in Chloroflexus aurantiacus. Proceedings of the National Academy of Sciences of the United States of America, v. 106, n. 50, p. 21317-21322, 2009.

ZEGLIN, L. H. et al. Bacterial and archaeal amoA gene distribution covaries with soil nitrification properties across a range of land uses. Environmental Microbiology Reports, v. 3, n. 6, p. 717-726, 2011.

ZEHR, J. P. et al. Nitrogenase gene diversity and microbial community structure: a cross-system comparison. Environmental Microbiology, v. 5, n. 7, p. 539-554, 2003.

ZHANG, Y. et al. Microarray-based analysis of changes in diversity of microbial genes involved in organic carbon decomposition following land use/cover changes. Fems Microbiology Letters, v. 266, n. 2, p. 144-151, 2007.

ZHOU, J. et al. Spatial scaling of functional gene diversity across various microbial taxa. Proceedings of the National Academy of Sciences of the United States of America, v. 105, n. 22, p. 7768-7773, 2008.

ZHOU, J. H. Microarrays for bacterial detection and microbial community analysis. Current Opinion in Microbiology, v. 6, n. 3, p. 288-294, 2003. 
ANEXO A

Propriedades físico-químicas de amostras de solo da Amazônia (continua) a

\begin{tabular}{|c|c|c|c|c|c|c|c|c|}
\hline Amostra & $\mathrm{C}$ & $\mathrm{N}$ & $\mathrm{C} / \mathrm{N}$ & $\mathrm{MO}$ & $\mathrm{pH}$ & $\mathrm{Al}^{+3}$ & $\mathrm{H}+\mathrm{AI}$ & SB \\
\hline F-A1 & 11.05 & 0.76 & 14.50 & 16 & 3.9 & 1.00 & 31 & 13.8 \\
\hline F-A10 & 8.73 & 0.72 & 12.15 & 32 & 4.5 & 3.00 & 31 & 25.1 \\
\hline F-A100 & 11.45 & 1.04 & 10.99 & 17 & 3.6 & 3.00 & 31 & 9.6 \\
\hline F-B1 & 7.81 & 0.68 & 11.53 & 15 & 4.5 & 6.00 & 18 & 20.4 \\
\hline F-B10 & 36.20 & 1.95 & 18.57 & 29 & 4.9 & 1.00 & 16 & 38.0 \\
\hline F-B100 & 12.75 & 0.95 & 13.42 & 36 & 5.2 & 0.01 & 18 & 54.8 \\
\hline F-C1 & 9.46 & 0.44 & 21.47 & 15 & 4.1 & 1.00 & 25 & 14.4 \\
\hline F-C10 & 12.45 & 1.16 & 10.72 & 18 & 4.6 & 2.00 & 18 & 22.9 \\
\hline F-C100 & 19.05 & 0.95 & 20.09 & 19 & 4.2 & 1.00 & 25 & 23.6 \\
\hline P04-A1 & 32.30 & 1.64 & 19.69 & 17 & 4.5 & 1.00 & 20 & 8.6 \\
\hline P04-A10 & 8.76 & 0.55 & 15.86 & 14 & 4.6 & 1.00 & 20 & 9.1 \\
\hline P04-A100 & 51.20 & 3.20 & 16.02 & 48 & 5.0 & 0.01 & 25 & 37.5 \\
\hline P04-B1 & 8.00 & 0.47 & 16.85 & 20 & 4.3 & 2.00 & 22 & 9.3 \\
\hline P04-B10 & 11.90 & 0.61 & 19.57 & 30 & 5.0 & 0.01 & 25 & 25.6 \\
\hline P04-B100 & 23.27 & 1.36 & 17.06 & 30 & 4.7 & 1.00 & 18 & 19.6 \\
\hline P04-C1 & 11.95 & 0.83 & 14.37 & 21 & 4.7 & 1.00 & 20 & 15.4 \\
\hline P04-C10 & 8.60 & 0.53 & 16.08 & 14 & 4.4 & 2.00 & 16 & 8.1 \\
\hline P04C100 & 19.90 & 1.40 & 14.21 & 26 & 5.0 & 0.01 & 20 & 18.9 \\
\hline P72-A1 & 11.95 & 0.67 & 17.89 & 25 & 4.0 & 2.00 & 15 & 12.3 \\
\hline P72-A10 & 16.80 & 1.08 & 15.62 & 28 & 4.6 & 2.00 & 20 & 12.5 \\
\hline P72-A100 & 22.05 & 1.36 & 16.18 & 28 & 4.6 & 2.00 & 22 & 18.5 \\
\hline P72-B1 & 16.30 & 1.09 & 14.97 & 29 & 4.6 & 1.00 & 22 & 15.4 \\
\hline P72-B10 & 21.60 & 1.13 & 19.08 & 29 & 4.6 & 1.00 & 22 & 14.7 \\
\hline P72-B100 & 12.50 & 0.72 & 17.46 & 23 & 4.6 & 1.00 & 22 & 13.0 \\
\hline P72-C1 & 16.45 & 1.07 & 15.39 & 30 & 4.8 & 1.00 & 22 & 15.9 \\
\hline P72-C10 & 16.30 & 0.96 & 16.90 & 29 & 4.7 & 1.00 & 25 & 18.3 \\
\hline P72-C100 & 17.55 & 1.10 & 15.99 & 29 & 4.5 & 1.00 & 25 & 14.0 \\
\hline P11-A1 & 25.30 & 1.69 & 14.94 & 42 & 4.8 & 1.00 & 34 & 28.2 \\
\hline P11-A10 & 29.15 & 2.13 & 13.67 & 37 & 5.0 & 0.01 & 31 & 30.4 \\
\hline P11-A100 & 62.80 & 4.83 & 12.99 & 57 & 5.0 & 0.01 & 34 & 51.4 \\
\hline P11-B1 & 33.67 & 2.09 & 16.11 & 39 & 4.8 & 1.00 & 31 & 28.8 \\
\hline P11-B10 & 29.60 & 2.29 & 12.91 & 39 & 4.5 & 1.00 & 34 & 32.8 \\
\hline P11-B100 & 14.55 & 1.24 & 11.73 & 36 & 4.4 & 1.00 & 38 & 18.3 \\
\hline P11-C1 & 22.70 & 1.65 & 13.72 & 41 & 4.6 & 1.00 & 31 & 25.9 \\
\hline P11-C10 & 22.35 & 1.63 & 13.72 & 38 & 4.9 & 1.00 & 31 & 32.5 \\
\hline P11-C100 & 27.85 & 2.17 & 12.85 & 36 & 4.4 & 3.00 & 47 & 15.7 \\
\hline S-A1 & 12.05 & 1.09 & 11.02 & 19 & 4.0 & 4.00 & 34 & 10.9 \\
\hline S-A10 & 16.80 & 1.52 & 11.08 & 14 & 3.7 & 7.00 & 34 & 5.8 \\
\hline S-A100 & 13.80 & 1.17 & 11.76 & 21 & 4.4 & 1.00 & 28 & 17.8 \\
\hline S-B1 & 36.03 & 2.17 & 16.59 & 14 & 3.9 & 4.00 & 31 & 6.7 \\
\hline S-B10 & 21.55 & 1.61 & 13.39 & 15 & 3.9 & 5.00 & 31 & 2.7 \\
\hline S-B100 & 16.15 & 1.22 & 13.22 & 15 & 4.4 & 1.00 & 31 & 11.8 \\
\hline S-C1 & 33.30 & 2.08 & 15.99 & 11 & 3.9 & 6.00 & 31 & 4.6 \\
\hline S-C10 & 20.75 & 1.42 & 14.63 & 15 & 4.3 & 3.00 & 25 & 13.3 \\
\hline S-C100 & 11.30 & 0.96 & 11.78 & 11 & 3.7 & 7.00 & 25 & 3.8 \\
\hline
\end{tabular}

${ }^{\mathrm{a}} \mathrm{C}$ e N estão expressos em g. $\mathrm{Kg}^{-1}$; Matéria Orgânica (MO) está expressa em g. $\mathrm{dm}^{-3} ; \mathrm{Al}^{+3}$, acidez potencial (H+Al) e soma de bases (SB) estão expressos em mmol c. $\mathrm{dm}^{-3}$. 
Propriedades físico-químicas de amostras de solo da Amazônia (continuação) ${ }^{\text {a }}$

\begin{tabular}{|c|c|c|c|c|c|c|c|c|}
\hline Amostra & $\mathrm{P}$ & $\mathrm{S}$ & $\mathrm{K}^{+}$ & $\mathrm{Ca}^{+2}$ & $\mathrm{Mg}^{+3}$ & $\mathrm{~T}$ & $\mathrm{~V}$ & $\mathrm{~m}$ \\
\hline F-A1 & 5 & 9 & 0.8 & 10 & 3 & 44.8 & 31 & 7 \\
\hline F-A10 & 7 & 10 & 1.1 & 14 & 10 & 56.1 & 45 & 11 \\
\hline F-A100 & 5 & 11 & 0.6 & 7 & 2 & 40.6 & 24 & 24 \\
\hline F-B1 & 5 & 9 & 0.4 & 16 & 4 & 38.4 & 53 & 23 \\
\hline F-B10 & 8 & 9 & 6.0 & 20 & 12 & 54.0 & 70 & 3 \\
\hline F-B100 & 9 & 12 & 1.8 & 43 & 10 & 72.8 & 75 & 0 \\
\hline $\mathrm{F}-\mathrm{C} 1$ & 5 & 8 & 1.4 & 10 & 3 & 39.4 & 37 & 6 \\
\hline F-C10 & 6 & 8 & 0.9 & 17 & 5 & 40.9 & 56 & 8 \\
\hline F-C100 & 6 & 9 & 0.6 & 20 & 3 & 48.6 & 49 & 4 \\
\hline P04-A1 & 3 & 9 & 0.6 & 6 & 2 & 28.6 & 30 & 10 \\
\hline P04-A10 & 3 & 9 & 1.1 & 6 & 2 & 29.1 & 31 & 10 \\
\hline P04-A 100 & 4 & 10 & 1.5 & 30 & 6 & 62.5 & 60 & 0 \\
\hline P04-B1 & 3 & 12 & 1.3 & 6 & 2 & 31.3 & 30 & 18 \\
\hline P04-B10 & 3 & 8 & 0.6 & 20 & 5 & 50.6 & 51 & 0 \\
\hline P04-B100 & 3 & 24 & 1.6 & 13 & 5 & 37.6 & 52 & 5 \\
\hline P04-C1 & 3 & 10 & 1.4 & 10 & 4 & 35.4 & 44 & 6 \\
\hline P04-C10 & 3 & 10 & 1.1 & 5 & 2 & 24.1 & 34 & 20 \\
\hline $\mathrm{P} 04 \mathrm{C} 100$ & 3 & 11 & 0.9 & 13 & 5 & 38.9 & 49 & 0 \\
\hline P72-A1 & 5 & 8 & 1.3 & 9 & 2 & 27.3 & 45 & 14 \\
\hline P72-A10 & 4 & 8 & 1.5 & 9 & 2 & 32.5 & 38 & 14 \\
\hline P72-A100 & 3 & 8 & 0.5 & 16 & 2 & 40.5 & 46 & 10 \\
\hline P72-B1 & 3 & 8 & 1.4 & 11 & 3 & 37.4 & 41 & 6 \\
\hline P72-B10 & 3 & 8 & 1.7 & 10 & 3 & 36.7 & 40 & 6 \\
\hline P72-B100 & 3 & 8 & 1.0 & 9 & 3 & 35.0 & 37 & 7 \\
\hline P72-C1 & 4 & 6 & 1.9 & 10 & 4 & 37.9 & 42 & 6 \\
\hline P72-C10 & 6 & 8 & 1.3 & 13 & 4 & 43.3 & 42 & 5 \\
\hline P72-C100 & 4 & 8 & 1.0 & 10 & 3 & 39.0 & 36 & 7 \\
\hline P11-A1 & 7 & 11 & 1.2 & 18 & 9 & 62.2 & 45 & 3 \\
\hline P11-A10 & 6 & 13 & 2.4 & 19 & 9 & 61.4 & 50 & 0 \\
\hline P11-A100 & 10 & 12 & 1.4 & 36 & 14 & 85.4 & 60 & 0 \\
\hline P11-B1 & 7 & 10 & 0.8 & 19 & 9 & 59.8 & 48 & 3 \\
\hline P11-B10 & 6 & 8 & 1.8 & 24 & 7 & 66.8 & 49 & 3 \\
\hline P11-B100 & 11 & 10 & 1.3 & 12 & 5 & 56.3 & 33 & 5 \\
\hline P11-C1 & 8 & 8 & 1.9 & 16 & 8 & 56.9 & 46 & 4 \\
\hline P11-C10 & 7 & 8 & 1.5 & 21 & 10 & 63.5 & 51 & 3 \\
\hline P11-C100 & 49 & 12 & 1.7 & 10 & 4 & 62.7 & 25 & 16 \\
\hline S-A1 & 6 & 13 & 0.9 & 7 & 3 & 44.9 & 24 & 27 \\
\hline S-A10 & 5 & 14 & 0.8 & 3 & 2 & 39.8 & 15 & 55 \\
\hline S-A100 & 5 & 9 & 0.8 & 13 & 4 & 45.8 & 39 & 5 \\
\hline S-B1 & 5 & 17 & 0.7 & 4 & 2 & 37.7 & 18 & 37 \\
\hline S-B10 & 5 & 19 & 0.7 & 1 & 1 & 33.7 & 8 & 65 \\
\hline S-B100 & 3 & 9 & 0.8 & 9 & 2 & 42.8 & 28 & 8 \\
\hline S-C1 & 4 & 21 & 0.6 & 3 & 1 & 35.6 & 13 & 57 \\
\hline S-C10 & 6 & 25 & 2.3 & 8 & 3 & 38.3 & 35 & 18 \\
\hline S-C100 & 5 & 13 & 0.8 & 2 & 1 & 28.8 & 13 & 65 \\
\hline
\end{tabular}


Propriedades físico-químicas de amostras de solo da Amazônia (conclusão) ${ }^{\text {a }}$

\begin{tabular}{|c|c|c|c|c|c|c|c|c|}
\hline Amostra & $\mathrm{B}$ & $\mathrm{Cu}$ & $\mathrm{Fe}$ & $\mathrm{Mn}$ & $\mathrm{Zn}$ & Silte & Areia & Argila \\
\hline F-A1 & 0.19 & 0.9 & 49 & 42.7 & 0.8 & 21 & 778 & 201 \\
\hline F-A10 & 0.22 & 1.0 & 92 & 45.1 & 0.9 & 40 & 809 & 151 \\
\hline F-A100 & 0.24 & 1.9 & 71 & 94.0 & 1.1 & 35 & 764 & 201 \\
\hline F-B1 & 0.2 & 0.8 & 32 & 34.0 & 0.5 & 18 & 781 & 201 \\
\hline F-B10 & 0.22 & 0.8 & 39 & 75.2 & 1.0 & 20 & 729 & 251 \\
\hline F-B100 & 0.32 & 1.3 & 45 & 73.4 & 1.3 & 20 & 755 & 225 \\
\hline $\mathrm{F}-\mathrm{C} 1$ & 0.2 & 0.8 & 43 & 43.4 & 0.4 & 16 & 758 & 226 \\
\hline F-C10 & 0.21 & 0.9 & 39 & 83.8 & 0.5 & 29 & 745 & 226 \\
\hline F-C100 & 0.23 & 1.2 & 57 & 29.5 & 0.6 & 39 & 785 & 176 \\
\hline P04-A1 & 0.15 & 1.3 & 107 & 11.0 & 2.3 & 25 & 548 & 427 \\
\hline P04-A10 & 0.14 & 1.4 & 111 & 18.9 & 0.7 & 17 & 707 & 276 \\
\hline P04-A100 & 0.2 & 1.4 & 277 & 36.4 & 1.1 & 14 & 635 & 351 \\
\hline P04-B1 & 0.14 & 1.3 & 68 & 19.3 & 1.0 & 17 & 632 & 351 \\
\hline P04-B10 & 0.15 & 1.0 & 88 & 22.8 & 2.7 & 42 & 631 & 327 \\
\hline P04-B100 & 0.15 & 1.2 & 99 & 20.8 & 2.6 & 16 & 584 & 400 \\
\hline P04-C1 & 0.14 & 1.0 & 52 & 24.9 & 1.6 & 30 & 694 & 276 \\
\hline P04-C10 & 0.14 & 1.2 & 63 & 12.7 & 1.3 & 19 & 453 & 528 \\
\hline P04C100 & 0.14 & 1.9 & 122 & 39.4 & 0.3 & 26 & 648 & 326 \\
\hline P72-A1 & 0.17 & 1.0 & 104 & 26.2 & 1.0 & 34 & 841 & 125 \\
\hline P72-A10 & 0.17 & 1.4 & 71 & 26.8 & 1.6 & 31 & 894 & 75 \\
\hline P72-A100 & 0.14 & 1.8 & 95 & 44.0 & 1.8 & 41 & 833 & 126 \\
\hline P72-B1 & 0.14 & 1.3 & 105 & 26.4 & 1.5 & 19 & 805 & 176 \\
\hline P72-B10 & 0.19 & 1.5 & 65 & 30.9 & 2.0 & 26 & 798 & 176 \\
\hline P72-B100 & 0.21 & 1.0 & 67 & 33.0 & 1.1 & 25 & 774 & 201 \\
\hline P72-C1 & 0.18 & 1.0 & 112 & 26.0 & 1.5 & 19 & 705 & 276 \\
\hline P72-C10 & 0.18 & 1.3 & 87 & 33.3 & 2.2 & 36 & 663 & 301 \\
\hline P72-C100 & 0.15 & 0.8 & 98 & 26.1 & 1.6 & 23 & 701 & 276 \\
\hline P11-A1 & 0.16 & 2.3 & 92 & 85.6 & 2.8 & 42 & 732 & 226 \\
\hline P11-A10 & 0.16 & 2.1 & 172 & 98.0 & 2.4 & 29 & 695 & 276 \\
\hline P11-A100 & 0.21 & 2.4 & 95 & 105.4 & 2.1 & 36 & 512 & 452 \\
\hline P11-B1 & 0.16 & 2.0 & 276 & 60.3 & 2.0 & 16 & 508 & 476 \\
\hline P11-B10 & 0.16 & 2.1 & 108 & 63.7 & 2.2 & 58 & 315 & 627 \\
\hline P11-B100 & 0.16 & 1.3 & 101 & 21.7 & 3.8 & 24 & 524 & 452 \\
\hline P11-C1 & 0.12 & 2.0 & 103 & 63.9 & 1.6 & 20 & 528 & 452 \\
\hline P11-C10 & 0.18 & 1.9 & 222 & 55.1 & 2.3 & 32 & 717 & 251 \\
\hline P11-C100 & 0.12 & 3.0 & 526 & 19.6 & 7.9 & 24 & 549 & 427 \\
\hline S-A1 & 0.22 & 0.7 & 41 & 259.8 & 0.8 & 35 & 689 & 276 \\
\hline S-A10 & 0.24 & 0.8 & 42 & 205.0 & 0.5 & 40 & 709 & 251 \\
\hline S-A100 & 0.16 & 0.4 & 44 & 134.4 & 0.5 & 21 & 779 & 200 \\
\hline S-B1 & 0.2 & 0.6 & 35 & 223.2 & 0.4 & 37 & 739 & 225 \\
\hline S-B10 & 0.21 & 0.5 & 35 & 207.4 & 0.4 & 28 & 746 & 226 \\
\hline S-B100 & 0.16 & 0.5 & 41 & 55.0 & 0.3 & 34 & 790 & 176 \\
\hline S-C1 & 0.21 & 0.6 & 34 & 182.4 & 10.9 & 24 & 800 & 176 \\
\hline S-C10 & 0.23 & 0.9 & 33 & 189.2 & 4.7 & 30 & 769 & 201 \\
\hline S-C100 & 0.21 & 0.7 & 36 & 151.4 & 0.4 & 23 & 827 & 150 \\
\hline
\end{tabular}

${ }^{\mathrm{a}} \mathrm{B}, \mathrm{Cu}, \mathrm{Fe}, \mathrm{Mn}, \mathrm{Zn}$ estão expressos em mg.dm ${ }^{-3}$; silte, areia e argila estão expressos em g. $\mathrm{Kg}^{-1}$. 